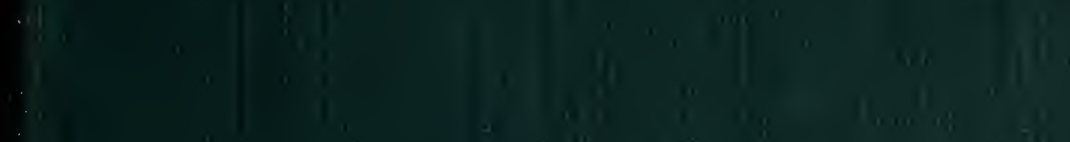




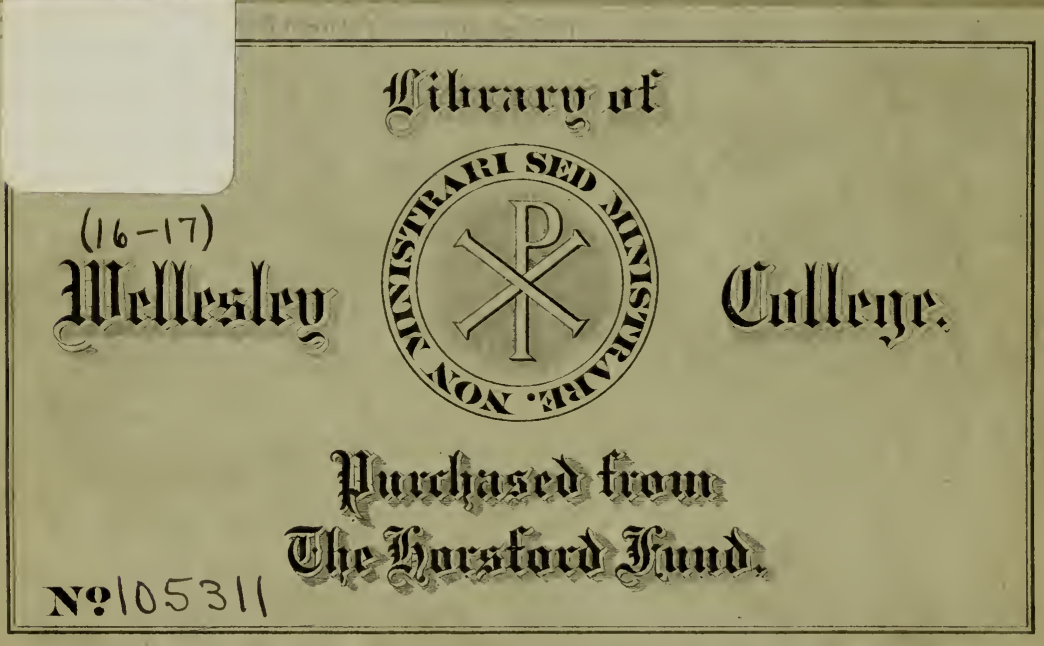





\title{
The Correspondence of Schweinitz and Torrey
}

\author{
Edited by C. L. Shear and Neil E. Stevens \\ (With PLATES 6 AND 7 AND THREE TEXT FIGURES)
}

\section{INTRODUCTION}

The two dominating figures in American botany during the early part of the nineteenth century were for more than a decade close friends and correspondents. Such of their letters to each other as are known to be extant, seventy-one in all, are here published practically entire, the only omissions being long lists of desiderata or accessions upon which no comment is made and which could be of use only to investigators working critically upon Torrey's or Schweinitz's herbaria, to whom the original letters are available. The letters are transcribed with but little alteration. Taken collectively, they furnish what is probably the most complete available record of the personal relations of these two American botanists.

Those who know Torrey only through his published work may be surprised at his early resolution to devote most of his time to the study of mosses, and no book-lover can fail to be amused at his good-natured irritation at paying "\$18.02" freight and duties on a box which contained for him only one book-one which he could not read. There may be historic value too in the fact that even a century ago the zealous household broom was considered an "enemy of science," and it is apparent that as much consternation was then caused in the botanical fraternity when a leading botanist showed interest in mineralogy as is now aroused when a cytologist diverts toward plant breeding.

As fairly comprehensive biographical sketches are available (see Britton, r3; Gray, 25; Shear and Stevens, 77; and Thurber, 85 ), little biographical detail is introduced. The publication of the letters was made possible by the cooperation of three American scientific organizations and several individuals. Permission to publish the letters was generously granted by Dr. N. L. Britton, 
Director in Chief of the New York Botanical Garden, Dr. E. J. Nolan, Secretary of the Academy of Natural Sciences, Philadelphia, and Dr. George de Schweinitz of Philadelphia. The letters from Schweinitz form a part of the Torrey correspondence preserved in the library of the New York Botanical Garden. Twenty-three of the letters from Torrey are in that portion of Schweinitz's correspondence which is the property of the Academy of Natural Sciences at Philadelphia and the remainder belong to Dr. Schweinitz. While the correspondence has not been preserved entire, the number of missing letters is surprisingly small.

In the work of editing, the writers have had the invaluable assistance of several of the members of the Torrey Botanical Club, particularly Drs. J. H. Barnhart, M. A. Howe, and A. W. Evans. The expense of printing has been borne by the Torrey Botanical Club as a tribute to the great botanist whose name it bears. The letters are published most appropriately one hundred years from the time the correspondence opened.

\section{THE CORRESPONDENCE}

The correspondence was begun by Torrey, a physician of twenty-three just beginning practise in New York City, asking assistance in the study of fungi of Schweinitz who, through the publication of a joint paper with Albertini (5), ${ }^{*}$ had already established a reputation in the mycological field. The letter is addressed on the outside to The Revd. L. D. Schweinitz, Salem, North Carolina.

TORREy to SCHWEINITZ

\section{Honored Sir}

NEw York, Decr. 29th, I8I9

Having long desired the honor of your acquaintance \& correspondence \& having no other method of gaining it, I have taken the liberty of obtruding myself upon you without a formal introduction-thinking, that among those of mutual inclinations \& pursuits, much ceremony is neither needed or expected. I have

* The list of the literature in the appendix was compiled by Miss Florence P. Smith of the Bureau of Plant Industry library. It is not a complete bibliography but is intended to serve for reference to the more important publications mentioned in the letters. 
for several years past employed my leisure hours in the prosecution of the study of Botany \& though I have some excellent company in the investigation of the higher orders of plants, in the study of obscure cryptogamous vegetables I am almost alone. The Fungi perplex me much, though it is not more than a year since I first attended to them with any success. Still I hope with the assistance I now entreat from you to study this difficult tribe of the vegetable kingdom much more effectually than I have hitherto done.

In the box which I have prepared for you, are some duplicates of Fungi which are sent to commence the correspondence I hope will be kept up between us. There is however, little inducement for you to attend to my communications. One who has so long attended to the subject, on which I solicit assistance cannot expect to receive much that will be interesting, from a novice. Should you nevertheless see fit to notice what I have sent, I should consider it a very great favour to have the names of the different species returned according to the numbers annexed to them. If a continuation of such communications would not be unacceptable to you I shall take the liberty to trouble you again ere long. A great number of species of Fungi have been observed by me in this vicinity, besides those now sent. A considerable part could be tolerably preserved, though many are of such nature that they cannot be dried. Of these-drawings or casts can be sent if desired.

I have found a species of Phallus which I suppose also grows near you, that I suppose to be $P$. impudicus of Muhlenberg's Catalogue [52]. It is however different from the $P$. impudicus figured in Sowerby [82] \&c. in having an indusium. The $P$. indusiatus of Pers[oon] resembles it in some respects, though it is probably distinct from this. If you know which species I refer to I will thank you for your opinion respecting it.

If I had known whether you are fond of the other branches of the Cryptogamia I should have sent specimens. I am exceedingly fond of the Musci \& Hepaticae \& can let you have those which grow here, if you wish them. Also rare Phaenogamous plants.

I am very desirous of increasing my collection of American plants, particularly of Cryptogamia, \& if I could offer you any 
thing that would be a sufficient return for those peculiar to the South, I should solicit you to send me specimens-Perhaps you may know some other person, who may be more profited by it, willing to commence an exchange of plants with me. I should be greatly obliged to you for your Monotropsis if you have specimens to spare.

Please to let me hear from you soon, \&

Believe me to be

Your obedt. \& humbl Servt.

JOHN TORREY

Revd. L. D. Schweinitz

P.S. March I 4 th 1820

Owing to adverse causes, I have been unable to forward the box before this, - I have now put it into way by which I hope it will reach you in good season-

Please to let me know whether you wish specimens in any of the other departments of Botany-

SChweinitz to Torrey

J. T.

Salem N. C. Stokes County

June 24 th, I 820

John Torrey Esqr. New York

Honored Sir

You can scarcely form an idea of the agreeable surprise I experienced a few days ago on the unexpected arrival of the Box with fungi \&c. which you have done me the honor to address to me. Opportunities for scientifical correspondence-more especially in a province of Natural History so utterly disregarded by most persons as are the Fungi, offer so rarely that I cannot express sufficiently the pleasure your kind letter gave me-nor pretend to thank you as I ought for the kind offers it contains. I embrace them with the utmost joy $\&$ hasten to assure you thereof by these lines, begging as a great favor the continuance of your correspondence. I should have immediately reloaded the box with specimens of Fungi \&c. \& sent it on to you-if I did not think it better first to comunicate to you what I can supply you with in order to avoid unnecessary things being sent. I shall therefore proceed in the first place to explain the different Lists contained in the inclosed sheet. 
The first list, I, contains the names of all plants (excepting Cryptogams) growing within my reach as far as I have observed them, which I do not find in the Catalogue of New York plants [Torrey, 86] you so obligingly enclosed (for which I beg to express my most cordial acknowledgements). If you will please to mark in your next which of these plants I can serve you with, I shall certainly send such of them as I have in duplicate as soon as possible \& take measures to procure those which I have not by me for a future remittance. Other southern plants, not immediately in our reach I may possibly be able to procure for you thro' my southern friends. The second List, II, contains those plants of your Catalogue which are wanting in my collection (or at least American specimens of which I have not seen) - \& I should consider it as a very great favor indeed if you could procure me any or all of them. The third List contains the names of the Fungi you have so kindly sent me. The names to which you find Nob. subjoined are of my own giving and are species which I had before observed here. No 49 [Gyropodium ? coccineum Nob. a new species*]. Gyropodium (a Genus I have ventured to make) coccineum is a species I have never found in Carolina but once observed in Pensylvania. The other species, Gyrop. lutescens, about six times as large is common here. No 9I [Merulius minutissimus, a new species-very distinct]. Merulius minutissimus is a beautiful new species. I think the name you give it very appropriate. No 95 [Nov. an Sph[aeria] herbarum denominand. This requires exam. by the compound microscope], found in your Herbar[ium] is a very interesting fungus entirely unknown. I shall submit it to a full examination under the great microscope as soon as I can. No I07 [nov. too indistinct to determine] is an extremly remarkable thing, but I can't make anything of it. Does it revivify? May it not perhaps be some morbid affection of the Fern on which it grows? No I08 [nov. Isaria antheriformis Nob. nov. spec.] - I have called Isaria antheriformis but should like to know on what you found it \& whether it was in a fresh state just as it is now. I think it a very curious thing worthy of being closely examined. No. 62 [Craterium clavatum Nob. Morchella esculenta], was double, the one the Morchella, the other a young

* [The portions in brackets are inserted from the accompanying list.] 
specimen of my new Genus Craterium, allied to Peziza. It grows with us to an enormous size changing from its Clavaria form to a remarkably shaped deeply turbinate Peziza. Some of the Specimens were rather indistinct. To these I have subjoined a (?).

In answer to your enquiry concerning the Phallus you have found I beg leave to observe that I have only once met with a Phallus here (altho I believe it not very rare but easily overlooked $\&$ requiring a wet season at a particular time, which generally with us is a dry one) \& that in its ovular state. But this one was doubtless the same as yours for it had an indusium tho' otherwise quite similar to the $\mathrm{Ph}$. impudicus of Europe. I could not determine it specifically on account of the young state. The later - mycologists of Germany call the Phalli indusiati-Hymenophallus - a new Genus \& I am confirmed by your observation in supposing this American species one not yet described; but I believe the $P$. impud[icus] of Muhlenberg is a different one \& the same European Phall[us] as my friend the Rev. Jacob Van Vleck informs me, that he has seen the Europ[ean] Phall[us] impud[icus] in Pennsylvania. What is the Phallus coccineus of your Catalogue? It is not a Clathrus I suppose? Mr. Leconte once sent me a drawing of the Clathrus from Georgia.

Having now answered your letter \& added that you cannot possibly do me a greater favor than by continuing your communications of plants \& fungi I shall beg leave to give you some information concerning my botanical labors \& collections, in order to enable you to judge wherein I could serve your wishes.

When I first came to Carolina I almost exclusively attached myself to the Fungi \& formed a considerable collection now amounting to about 1500 Species, entirely from our immediate neighborhood, which still keeps increasing. Of these rather upwards of I Ioo Species are identical with European ones, the rest appear to belong exclusively to our continent many of these necessarily, from being parasitical on merely American vegetables; others may probably occur in Europe likewise, as it is but of late that the Fungi have been closely examined there. Of the preservable ones I have with few exceptions preserved specimens in my collection (the Agarici \&c. except the Pleuropodes I exclude entirely because altho' they may be dried they lose all their characteristics, 
\& try to make drawings of such as appear new) \& at the beginning of this year I have commenced an augmentation in such a manner, that I have 5 parallel collections as complete as I can obtain specimens in order to send to friends who wish to have them. Please therefore to let me know what species you have firmly established \& I- shall send you specimens of all the rest of mine of which I have any-for I don't like to send such as you are already sufficiently acquainted with, as these may be wanted by some other friend. My catalogue of Fungi, together with descriptions of all the new species by me established \& specimens of them, I took with me to Europe on my visit there in the year I8I7-I8 \& left them in the care of Dr. Schwägrichen at Lipzic to make use of them at his discretion [75]. Since my return, having provided myself with instruments \& books I have pretty zealously turned my attention to the Musci, Jungerman[niae] \& Lichens \& sweet water Algae, \& have succeeded in determining a considerable number. Especially Lichens \& Musci hepat[ici] we are rich in. I have found above 300 species of the former, \& about 50-60 of the latter. Of all these (or at least of most of them) I have duplicates \& am continuing their collection, so that you can get them as soon as arranged \& separated which however cannot be done on account of my avocations of duty before the end of next winter. What has been of great service to me was the happy circumstance that I succeeded in procuring from Dr. Schwägrichen \& other botanists of Germany specimens of the greater part of the German musci, hepat., Lichens, \& all their [sweet] water algae-by which I am greatly aided in determining our plants. In the mean time I have not neglected the Phaenogamic plants. My German friends liberally furnished me with the greater part of those growing on the continent \& I have added a considerable number of the American ones, so that my Herbar[ium] which I have arranged handsomely \& convenient, now contains, includ[ing] Cryptog[amia], near 6000 plants altogether from their native soil either of Germany \& England, or America. Lately I have conceived some idea of preparing an English \& Latin work on the Cryptogamia of the United States or of North America generally \& you can therefore judge how much I wish that botanical Friends like yourself would aid me by communicating 
Specimens of Cryptogamists of America generally. The catalogue you sent me is rather deficient in these, but I presume you have a collection that contains more species. In my next I will try to send you a Catalogue of all my American Cryptogamists; but in the mean time you will greatly oblige me by any you can spare. Does the Sea in your vicinity afford any variety of Fuci \& Confervae? This division is naturally entirely out of my reach except by the kindness of friends; my European specimens are pretty numerous - \& I have about 25 species of sweet water Algae here \& hope to find more. Mr. Elliott has sent me lately a fine collection of South Carol. Fuci \&c. Can Decandolle Species Plantar. [ I5] be procured in New York \& what is their price?

Any parcel you wish to send me reaches me safely when addresed to Mr. John Jordan, Philad[elphia], or Jacob \& A. Ritter, Philadelphia. The latter address I prefer because Mr. Ritter more frequently sends goods hither. I would thank you to favor me with your address more particularly. 'I shall certainly send a specimen of my Monotropsis (sit venia nomini barbaro, while Nuttall has not mended the matter by my own still more barbarous name) with my first remittance to you. Accept, dear Sir, my hearty thanks for the favor of your correspondence \& let me indulge the hope that you will continue it \& thus oblige

Your most obedt Servt

Lewis D v Schweinitz

By the Rev. C. F. Denke lately established in our vicinity the botanical fraternity of North Carolina has obtained a valuable recruit \& now forms a quadro. Rev. Jacob Van Vleck, C. F. Denke \& myself here, \& Prof. Mitchell at Chapel Hill. I am afraid there is no other soul in the state. When you do me the honor to write pray let the letters be directed to R[ev. Mr. Schweinitz, *] Salem Stokes County North Carol[ina], \& put them into the mail at New [York*]. They reach me much sooner than by inclosure to Philadelphia. I would [ask $\mathrm{as}^{*}$ you to inform me where my friend Mr. John Leconte is at present.

Your Gratiola neglecta gave me much pleasure; I had observed it here this year $\&$ had made out the same name for it, a coincidence

* [Words supplied by the editors, the letter being torn.] 
trifling in itself but I can't help liking such trifles as omina fausta! Looking over your letter I can't help remarking upon the epithet "difficult" which you attach to the study of the tribe of Fungi. I am of opinion that it is by far the easiest of the Cryptogamic divisions. The species are much more characteristically divided $\&$ when once you have a considerable number in your mind you will rarely be at a loss. Wherever there are a considerable number of varieties attached to some species among the Fungi they almost always partake so strongly of the specific characteristic that they rarely occasion doubt.

\section{Torrey to SCHWEINITZ}

Respected Sir

NEW York July 29th I 820

Your highly interesting letter of the 24 th of last month I received after much patient waiting. I had begun to fear the box I sent you had miscarried, but I was agreeably disappointed at finding it had not only reached you in safety, but that my numerous queries were so satisfactorily answered. I exceedingly regret it is not in my power to be a more useful correspondent to you, but if I supply some of your desiderata it will amply satisfy me for what little trouble it may occasion. I shall take a particular pleasure in sending you not only all the fungi I can procure but specimens of all other cryptogamous \& phaenogamous plants of which I can procure duplicates. As I am a young man \& engaged in the practice of physic it is impossible for me to pay much attention to the study of natural history. However, by oeconomising my time I hope I shall, in time, accomplish something. Besides I have an extensive correspondence with all the botanists of the Northern States who supply me with every thing not growing in this vicinity, so that with the assistance of my friends my correspondence may not be altogether useless to you.

You would do me a particular favour by furnishing me with your specific characters of the Fungi you consider new among those sent to you as you probably described them in a fresh state. I was a little surprised that there were only two species of Sistotrema - they perplexed me as much as any others of the Fungi. The Isaria antheriformis I found in my herbarium, 
in a part which had accidentally got wet. That other little fungus which I found in my herb[arium] I hope you have by this time determined-Do let me hear from you on the subject in your next letter.

The Phallus having an indusium, is quite common here some seasons \& always has the indusium very distinct. When it appears again I shall prepare a specimen according to Withering's process \& send it to you. The other species which I call P. coccineus is figured by Sowerby in his 3rd Vol. of Eng[lish] Fungi [82]. - It may not be a real Phallus though I suspect it is the species meant by Muhlenberg who has a $P$. coccineus in his Catalogue [52]. Your desiderata from my Catalogue [86] I shall take the earliest opportunity of supplying, \& as I collect sufficient to make up a package it shall be punctually sent to you.

For your kind offer to send me such plants as grow in your vicinity \& which are not in my Herbarium I return you my sincere thanks, \& any of those in your list except those enumerated on the next page would be highly acceptable to me.

Several of my botanical friends have expressed a desire to enter into a correspondence either with yourself, Mr. Denke, Mr. Van Vleck, or Professor Mitchell, but as I shall send you everything from this region \& they have free access to my collection, perhaps it would be better for them to communicate with either of the three latter gentlemen, as we should then receive among us a greater variety than perhaps you yourself would take the trouble to send. Mr. Cooper, a young gentleman of leisure \& fortune of this city, who devotes most of his time to study has put into my hands to be transmitted to you (he being now absent from the city) a small package of plants which you can dispose of as you think fit. His letter which accompanies his package will explain his views. Mr. Halsey-another young but accurate botanist, wishes me to send a package on his account. In my next remittance to you I shall put up duplicates of such other cryptogamia as I possess duplicates of, \& also such phaenogamia as you want \& I can supply you with. I hope you will take the earliest opportunity of forwarding to me some of the plants I desire, \& do, if possible, put up a few cryptogamia. Respecting the Fungi I have collected, \& which you wish me to furnish you with a list 
of, I would remark, that my knowledge of this tribe of plants is so limited that if I were to draw one up it would only mislead you. Please therefore to send me almost anything not in the catalogue of New York plants [86], \& not in the collection I sent to you-especially your new species.

I am making great exertions to extend my collection of foreign cryptogamia \& I have already a great many species. Profs. Sprengel, Treviranus, \& Agardh have sent me fine collections, \& so has Mr. Casström of Stockholm, Mr. Sealy of Cork, \&c. With the aid of these I study the species of this country with more satisfaction than I otherwise could, but still I labour under considerable difficulty for want of books. I want Schwägrichen's supplement [66] \& many other books. Agardh informs me he has finished his Species Algarum [3]. I would wish to know whether the Supplement to Persoon has ever been published. The Synopsis [59] is now becoming antiquated.

Any plants in your list No I except these below (which I already possess) would be highly acceptable [Lists 88 species]

I rejoice to hear you [say] that you have turned your attention to a work on American Cryptogamia. I hope nothing will occur to prevent what is now so great a desideratum. It is really a reproach to our botanists that none of them except Dr. Muhlenberg ever attended to this interesting department of Botany. Should the Flora Lancastriensis[*] ever be published we shall have much assistance in the Orders of Musci \& Lichenes, though the Father of American botany did not neglect the other families.

Mr. Nuttall [55] seems to hint that Mr. Collins will publish something on the Cryptogamia of this country (in his preface). But I think it is very doubtful as this gentleman carries his caution so far that it is difficult to get his opinion on the most common

* [Youmans, W. J. Gotthilf Heinrich Ernst Muhlenberg. Pop. Sci. Mo. 45: 693, 696. I894. Reprinted in Youmans, W. J. Pioneers of science. . . New York. I896. "In July, I785, Muhlenberg communicated to the American Philosophical Society an outline of a Flora Lancastriensis (flora of Lancaster) containing the results of his own observations on the plants and their habits. . . Unfortunately they have not been published." A list of the plants described in this manuscript was, however, published by the Society (Trans. Am. Phil. Soc. 3: 157-184. 1793).] 
plant. I have sent him, repeatedly, packages of plants for examination, but he never answered me a word respecting them-

Do let me hear from you soon, \& Believe me to be

Your obed. servt

JOHN TORREY

P.S. I shall dispatch for you to Mr. Ritter's care, Phil. in a week, or ten days-Mr. Le Conte is in this city but attends little to Botany as the duties of his office occupy all his time.

\section{SChWEInitz TO TORREy}

\section{Dear Sir}

SALEM October 22d I 820

Your highly esteemed letter of July 29th reached me in due time \& gave me the most sensible pleasure. I should undoubtedly have answered it on the spot, had I not wished to accompany it directly with a box containing some of those plants \&c. which you desired from me, which I found no leisure to get together before this. I now however have the pleasure to inform you that I have made up a box for you, which is to proceed on to Philadelphia in a week or two, the contents of which I shall beg leave to specify below. Your kind offers of providing me with what I still want in my collection are exceedingly acceptable; especially as you can perhaps procure for me northern plants from other Botanists, even should they not grow in your vicinity. With a view to point out such I beg leave to inclose a list of such as I had some time since made out-which however contains numbers of those that are included in your Catalogue [86]. I need not add that it will be a great pleasure to me to serve you \& your friends with everything I can command.

Your request as to specific characters of the new fungi sent me by you I shall gladly comply with, but must beg your indulgence in that respect $\&$ with regard to further communications of fungi till towards Spring as it will take me nearly all the winter to arrange \& describe what I have on hand.

I have since the receipt of your letter had the good fortune to find both the Phallus coccineus (as I take it to be-tho' not possessed of Sowerby's Fungi [82] - a Phallus beyond all doubtI have made a drawing of it) \& the $P$. impudicus (non indusiat.). 
My friend Rev. J. Van Vleck altho very zealously attached to the study of botany is on account of his age no longer able to collect plants. But Mr. Denke on the other hand, with whom I have planned for the next year two excursions into our southern mountains-promises great activity \& I hope thro' his means chiefly to be enabled to procure for you, Mr. Cooper, \& Mr. Halsey, from whom I have received a letter which is answered by the enclosed \& by a little package contained in your box, \& other friends everything that we can get at. I was not a little pleased to find that you correspond with so many of the European botanists-especially with Agardh in Stockholm whose Species Algarum [3] I most earnestly desire to procure \& beg you to let me know what is the title in full. Perhaps you may be able to let me have some European Cryptog., if you are supplied with duplicates-\& I shall try to communicate to you occasionally a list of those I possess in order to see whether you can do so. No supplement to Persoon [59] has ever been published to my knowledge. But a most excellent work on the Fungi by Nees von Esenbeck [53] (barring the nonsensical metaphysics which pervade the reasoned part of it) full of the most accurate observations \& truly deep reflexions entirely in the German language is in my hands, which will be of great advantage. There is a volume of Copperplates belonging to it which renders the book pretty dear. I am now anxiously expecting the box you have sent on to me, by the return of the waggons which take the one I send you to Petersburg. It would be a fine plan to keep boxes continually under way in this manner. Should you have opportunities to send on directly from New York to Petersburg in Virginia Addressed to Caldwell \& Orr it would greatly facilitate the business (giving me notice as of ten as you have sent them a box) \& if you in that case would so desire it, it would perhaps be equally advantageous for me to order what I can send you directly from Petersburg for New York. My project of writing a work on Am. Cryptog. will depend much on the contributions I may receive from others. I am sorry to observe that not all American botanists are as free as yourself in comunicating their observations - which I cannot comprehend-it always being my greatest pleasure to do so. I now advert to the contents of the box I have made up to you it contains I) 237 Phaenogamous plants 
such as I conceived by your directions would be acceptable and as I had on hand. 2) a number of Fungi that I had put up for the purpose collected before this year. Of both I have retained lists, so as to know what I have already sent you, when again able to make up a packet. The following is a list of the Phaenogamous plants. [The list of 237 flowering plants is here omitted.]

These are put up in paper at the bottom of the box, \& labeled with the names under each plant.

The fungi are wrapped up separately in papers \& the name written on. Some of them probably were among those you sent, but as they are not many I did not take the trouble to pick these out, as this collection was made up before I received yours. My next box will contain a good number of Fungi which remain to be assorted \& I shall take care to send none of those you have already. By my list the present collection contains [the list of I98 fungi is here omitted].

I am apprehensive that some specimens of the Fungi will not be distinct enough. In that case I shall always be ready upon your naming them (except where this indistinctness arises from the difficulty of preserving them) of sending you better specimens if I can get them. It is pretty troublesome to preserve them properly - as to the Agarici \& Boleti of soft texture \& other similar ones I have never made an attempt-but chiefly made drawings of them.

You will no doubt be so kind as to hand the inclosed packet \& letter to Mr. Abraham Halsey, \& if Mr. Leconte is still at New York you will oblige me much by letting him know that I wrote to him at some length a good while ago requesting his directions concerning the copying of my Fungi, but have not received an answer. I remain with the greatest respect

\section{Your most obdt Servt}

\section{LEWis D v Schweinitz}

P.S. I just observe that the Tuber cibarium is among the Fungi in your Catalogue of N. [Y.] Plants [86]. I have never seen that, altho I have looked for it with great pains-if you can send me some specimens it will oblige me very much. 


\section{Schweinitz to Torrey}

\section{Dr Torrey New York}

SAlEm January II th I 82 I

\section{Dear Sir}

With a confident hope that the box of plants which I addressed to you has by this time arrived (having had news of it as far as Philadelphia) \& given you some little satisfaction, I beg to express to you the extreme delight the receipt of your Package of plants shortly after mine were sent off gave me, together with those sent on by Mr. Wm. Cooper to whom I shall write a few lines today.

I should have written to you in answer earlier than this day, if I had not thought it would be more agreeable to you to receive my list of the delightful quantity. of Cryptogamists includedwhich required time to be examined. I now have the pleasure of subjoining that- \& have succeeded in determining them all-with the exception of a very few that were either too indistinct or which I had the misfortune to lose by their dropping into a heap of rubbish as I was going to examine them-from which they could not be extricated. Altho' I was extremely gratified by the Phaenogamous plants you have so kindly sent me, \& earnestly beg you will be so good as to continue-still I must confess. I was still more delighted by so fine an assortment of Cryptog. especially of Musci. Those arrived in excellent time just as I was commencing a thorough examination of my whole collection, \& of a good large bag of Mosses collected in Canada by my friend Mr. Denke-so that I believe I can say they have been pretty well ascertained; it is of great importance in the exam. of Musci, that you should have as great a number together as possible. The results of my labors on the Musci frondosi et Hepatici has been the following.

I find mention made in Authors of

Muscifrond. 276 Species Ameri- Of these I possess 263 from can ones including a number which I have found, not heretofore mentioned as American \& a very few new ones established by me.

America so that I at present only lack I3 species of hitherto described Am[erican] Musci frondosi \& of these there are only 4 species which are not in my collect[ion] fr[om] Europe. 


\section{The Correspondence of Schweinitz and Torrey}

Musci Hepat. 76 Species recorded or found by me, of which some are new.

The whole number
Only two of these are not in my American collection.

of Musci Frondosi in my Collection is 442 species
of - - hepatici --

Of both Frondos \& Hepatics I have put up for you specimens of all of which I had duplicates - that are not mentioned in the New York Catalogue or among those you sent me, besides a considerable number of European ones from my duplicates which are always distinguished by being in blue paper.

I am now on the point of reviewing my Lichens in the same manner. I have 562 species in my collection of which no less than 44I are American ones. When I have finished this work I shall have about sufficient to send on another box to you. The way which we have begun of thus communicating specimens of Cryptog. is the only one I believe which will enable us at length to get a competent knowledge of the immense numbers of Am. Cryp. plants-\& I therefore earnestly solicit you to send on in the same manner, whatever you think proper to communicate to me. I shall always send you back a similar list, with the one here inclosed-containing my opinion on all the spec. communicated.

I think I have mentioned to you my idea of publishing a Cryptogamic Flora of N. America. I am now in communication with a printer at Raleigh for publishing a specimen of such a work [74], which I intend shall contain the Musci hepatici, on account of their limited number. My plan is that such a work should be as a kind of second part to Pursh [6I], \& therefore modelled upon his plan; \& the specimen I intend to give will enable scientific friends to judge whether that be a good plan. My only fear is the size of the work-for imperfect as my present collections are the whole already amounts to a very large number, Fungi I700, Lichens 44I, Musci, 352, \&c. \&c., so that it must comprise near 2500 species. Besides I should not pretend it to be anything besides a Prodromus, for the purpose of calling the attention of Am. Botanists to this part of the Science. Our higher mountains, \& our southern swamps \& seaboard must necessarily contain immense numbers of Crypt. plants hitherto quite overlooked. I am preparing for an 

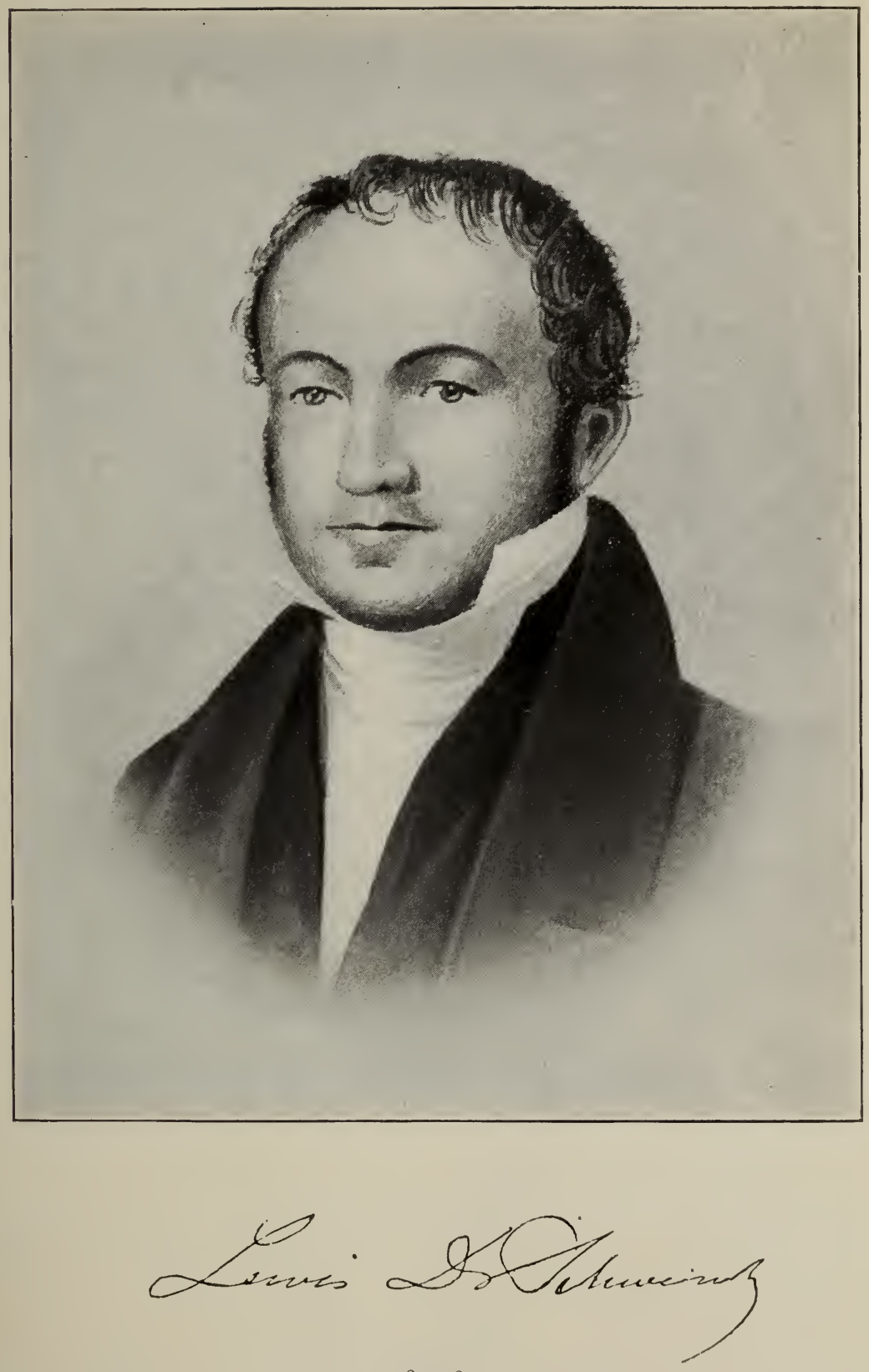

I 780-I 834 

expedition to the Grandfather mountain this spring, chiefly with a view to Cryptog.- but unhappily have little prospect of being able to get into our famous Dismal swamp \&c. of whose fertility I have a still better opinion especially in M. frond. \& hepat. Can you procure me information as to where Mr. Nuttall now resides? I wish much to become acquainted with him, \& to propose some questions to him concerning the Crypto. of the Western country.

This year I shall exert myself together with Mr. Denke in collecting all Phaenog \&c. plants which our neighborhood contains in order to be able to meet the wishes of you, Mr. Cooper \& Halsey (this latter gentleman writes me that he has sent on a parcel for me which however has not yet arrived). I intend to send you a copy of my list of Am. plants generally not yet in my collection-hoping that you might perhaps procure some for me, not growing in your vicinity, by perhaps receiving duplicates from others. The small list now inclosed by Right Rev. Jacob Van Vleck designates such of your Catalogue as he would be glad to procure-\& on the other page I repeat to you a more correct list of those which I myself should be glad to receive from your Catalogue, together with the few American mosses which are wanting in my collection. I hope you will find time shortly to let me know how the plants I sent you answered your wishes-With the greatest respect I remain Yours most Sincerely LEwis D v Schweinitz

P.S. Do you think Dr. Silliman could give place in his excellent work [American Journal of Science, 6] to a short review of the Musci frondos of Am?

Musci frondosi Americani-non in Herbario LD v S. [Lists I3.] What is intended by the Hypn[um] cupressiforme in your Catalogue? \& Hypn[um] setaceum Whence is the name? Targionia hypophylla-among the M. hepat. is said to be in America-have you met with it?

Revised List of Phaenog. \&c. plants in New York Catalogue, wanted by me. [Lists I24.] 


\section{TORREy TO SCHWEINITZ}

L. D. Schweinitz EsQ̨.

NEw York, March 22nd I82I. Salem, N. C.

Dear Sir

Although your highly acceptable letter has been received nearly two months it has not been in my power to answer you according to my wishes until now. I was desirous of making some observations on the very choice collection of plants you had the kindness to send me, \& this required more time than I could, until lately, spare. Mr. Nuttall, who was on a visit to this city a short time since, examined the collection with me, \& our observations I shall give you below. I wished also to have it in my power to give you notice of another box of plants which will be ready to send to Petersburg in two or three days.

I thank you sincerely for your remarks on my Cryptogamia \& hope you have found sufficient among them to reward you for the trouble they occasioned you. You do not agree always with Sprengel to whom I have at different times sent many of the specimens I send you. You will see below in what you differ. Indeed this great diversity in opinion among equally great botanists almost discourages me from pursuing the study of the Cryptogamia. I of ten find as many different names given to the same plant as persons to whom I send it. Tis true Tetraphis pellucida, Dicranum scoparium \& such well marked species are not in this predicament, but in the genus Hypnum, Lecidea, Thelephora \&c. \&c. I seldom find two botanists to agree on a name. With all deference however to the learned Professor of Halle, I often differ from him in opinion \& would ask of you whether his sight does not begin to fail him.-I am not jesting.

It gives me great pleasure to hear that we are at last in hopes of having a Cryptogamic flora of the United States. You are probably in possession of a greater quantity of materials for this purpose than any other person in this country. I hope you are well acquainted with all the species which Muhlenberg mentions in his catalogue [52]. Did you correspond with him? He has some species whose names I can not find in my books. You may depend on receiving everything from me which will be of any assist- 
ance in your work, \& I believe you will then have all that has been observed in the States north of Pennsylvania. All the botanists here send me everything they collect; so that I can thus do for you a great deal more than I could do alone.

You enquire respecting Mr. Nuttall.-I mentioned just now that he had lately made a visit to this city, but he resides now in Philadelphia. Mr. N. returned last spring from another expedition up the Missouri, \& into the Arkansas Territory. He spent the year 1819 there \& discovered a great number of new plants-probably about 300 species. He is now printing his Journal [56], but his botanical discoveries [54] he is preparing to publish in the next volume of the American Philosophical Trans. of Phila. He found comparatively few cryptogamia, \& all of them except the Ferns, he has given to Zaccheus Collins Esq., of Phil. This gentleman has undertaken to examine them, as Mr. Nuttall has not paid great attention to this department of Botany. I doubt much however whether Mr. C. will consent to have his opinion of the specimens published, even if he should give any opinion. It is surprising how exceedingly cautious this gentleman is in this respect; for the (perhaps) hundreds of specimens which I have sent him, he has never returned me the name of one-You had better however write to him, as he may send you specimens if he will not give you descriptions \& names of plants. Mr. Nuttall found on the Red \& Arkansas Rivers, Pilularia, \& Marsilea, which have not before been observed in North America-I have duplicates for you which shall be sent soon.

I am very glad you are so much inclined to continue in correspondence with me and my friends-It will no doubt be in my power to furnish you with many northern plants that do not grow in this neighborhood, as I am in active correspondence with most of the botanists in this part of the country. I intend soon to put up a package for the Right Rev. Mr. Van Vleck \& shall be happy to open a correspondence with him on Botany.

You ask whether Mr. Silliman would give place in his Journal [6] to a short review of the Musci frondos, of N. Am? I answerundoubtedly \& if you send it soon it will be in time for the next No. You can send it directly to him, \& transmit it to my care-

Remarks on the plants you kindly sent me last fall: 
Gratiola sphaerocarpa-Is this not near our neglecta?

Lycopus exaltatus. If this is really distinct from $L$. europaeus can it possibly be the plant described in the Fl. Graec. [Sibthorp, 78]? I have only seen the Prod. Fl. Gr. [Sibthorp, 79] \& therefore cannot decide whether it resembles the plate. L.europaeus, with us, looks very much like your plant.

Carex gynandra we have here, \& I could not make it out. I think I have several new ones.

Cyperus uncinatus has a very great range, for I have it from Vermont, Massach.-Connecticut \& N. York-Perhaps it is C. squarrosus of India? You know it is the C. inflexus of Muhl.? C. mariscoides-of whom? Our Mariscus cyperiformis (Scirpus! cyperiformis Muhl.) is now called Cyp. mariscoides by Sprengel, but it is not your plant.

Houstonia longiflora, is H. tenuifolia Nutt. Gen.

Phacelia parviflora Nuttall thinks is not that plant, though he does not name it.

Viola eriocarpa.-Is it distinct from. pubescens? $V$. pub[escens] $\beta$ Nutt.?

$V$, ochroleuca, looks like V. striata Nutt. \&c.

Thaspium actaeifolium. Is it possible this is the real Ligusticum actaeifolium of Michaux \& which he found on the Banks of the St. Lawrence!?

Sesbania herbacea is Trigonella americana Nutt.

I find I shall not have room here to make any further remarks on your plants, \& shall therefore proceed to give the differences between your names of my Cryptogamia, \& Sprengel's. I shall say more respecting your plants at another time.

No 47 Herb. "Hyp. lutescens" Schweinitz is Spr. H. populeum.

53 Cooley. "cupressiforme" Sw.- is incurvatum Spr.

9 Herb. Dew. "hians" Sw. is "salebrosum Hoffm. v[ar.] plu$\operatorname{mos}[u m]$ Hedw." Spr.

H. 20 Dew. "oxycladon" Sw. is salebrosum Spr.

8 Herb. Dew. "confertum" Sw. is imponens Spr.

Hyp.-v. "commutatum" Sw. is imponens Spr.

Hyp.-q. "adnatum" Sw. is "molle Dicks." Spr.

"Hyp. curvifolium" Sw. is H. cristacastrensis Spr.

Lesk.-I9 "L. sericea” Sw. is Neckera cladorh[iza] Spr.

No 78 "Leskea varia" Sw. is Hyp. radicale Spr. 
Gymnostomium repens, at first sight, looks much like an Orthotrichum, \& was mistaken by me for a species of the latter genus in an advanced state. Sprengel returned it as an Orthotric.-I believe anomalum. Do you not think Anoectangium filiforme, quite distinct from A. ciliatum? Bridel makes it a variety \& Schwägrichen does not notice it. Didymodon I erroneously called Dicranum rigidulum, though I knew better. It is a variable species, at least in height, which may be the cause of its not always resembling the European D. rigidulum. Really I must own that I hardly think the moss you called $D$. virens, the same as the European specimens I have under this name.

My Jungermannia nodifolia, Sprengel calls J. ciliaris! \& your $J$. platyphylloidea he says is $J$. platyphylla - by the way is not your name objectionable? Your Blasia pusilla he calls Jung. pinguis-You may think it presumption in me to differ in opinion from two such celebrated botanists as Sprengel \& yourself, but this plant though I suppose it to be a Jungermannia seems to me quite distinct from pinguis. Will you examine it again? Thelotrema cinereum Swtz. Sprengel calls "Pyrenula (!) enteroleuca*. n. sp."

"Evernia prunastri" Sw. is Borrera furfuracea Spr.

No. 152 Herb. Cooley "Cetraria lacunosa aut nova " Sw. Sprengel says is "Nephroma resupinata $\beta$ papyracea"

"Cenomyce phyllophora" Sw. is C. gonorega var. pleolepis Spr.

In a letter I lately received from Prof Sprengel, in some remarks on some plants I sent him, he says-"Your fungus, no. I 08 , found in your herbarium has afforded me great joy, as this is a most rare plant which has been named by Willdenow, Blandowia. Its place is between Anthoceros \& Targionia. B. striata IV. Berl. Magaz.? Cfr. Micheli Nov. Gen t. 4, f. 5.-Laetitia singulari se afferit!" Now there is something I do not understand in all this, for I can not be mistaken when I say the specimen is the same which I sent to you, exactly as I sent it to Sprengel, called by you Isaria antheriformis. There is certainly no resemblance in it to either Targionia or Anthoceros, \& is most certainly a fungusIt grew I think in the damp paper of my herbarium.

- I have just received from the Author (Agardh) the Ist volume of the Species algarum [3]; comprising the Fucoideae. It is a valuable work. 
The box for you which I shall probably put on board a Petersburg vessel tomorrow, contains nothing but Cryptogamia. There are 200 species of all orders. Very few are named altho' I think I have determined a good part of them. Mr. Eaton [20], who is writing a little work on Botany, took away into the country, 6 months ago, all my books on Cryptogamia, so that I have not studied scarcely any of the specimens I now send you from books. Some of them I think are new, \& many have probably been sent before.

Very respectfully, I remain Yours \&c. JOHN TORREY

P.S. Please to send your opinion of the names of the Cryptogamia as soon after you receive them as convenient. I hope to receive the box which you mentioned in your last letter you was preparing for me. If it has not yet been sent off please to hurry it a littleI am very anxious to see it. Mr. Halsey sent you a package a few weeks since.

Schweinitz to Torrey

J. T.

SALEM April igth I82 I

Dr John TORrey New York

Dear Sir

At length I am able to forward to you a box containing the greater part of the Cryptogamical plants of every division which I had on hand-having been prevented from doing so sooner first by the uncommon season $\&$ then by a wish to enclose you a copy of my Specimen of Fl. Cryptog. cont. the Hepatic mosses [74]-of which however the printing progresses so slowly that I can no longer wait, as a good opportunity offers for sending the box. You may however depend on receiving a copy as soon as it is finished, \& I should be glad if you could dispose of some for me, as I wish not to lose too much on the little work. This delay has however afforded me the extreme pleasure of receiving in the mean time your invaluable letter of the $22 \mathrm{~d}$ of March, which I can now answer. But first I beg leave to say a few words concerning the plants I this day send to Petersburg for you, a complete list whereof the inclosed sheet contains.

I am extremely sorry that my collection did not afford more 
perfect specimens of many \& would be glad if you would note down such as on examination prove too imperfect in order to enable me to send better from the new collections making for the purpose. Among the Musci frondosi all those underlined in the list are European specimens. I have given you the names by which I designate the rest, according to my determinations, but will not be quite positive about a number-It is impossible to be quite certain until repeated examinations \& comparisons have taken place. This remark I wish to apply particularly to the Lichens-some of which certainly ought to be revised. But the winter season, which makes that practicable, proved too short for the purpose this time. By next year I hope not only to be able to speak with more certainty but to communicate to you a number more. In the box you will find several envelopes directed to $\mathrm{Mr}$. Abr. Halsey. They contain Lichens (the same species which I send to you altho not so many) which you will oblige me to hand to him. I shall now proceed to answer your highly agreeable and instructive letter-after expressing to you my sincere thanks for your observations, \& for the promised Box of about 200 cryptogam. plants, which I hope to receive by the returnof the waggon which brings my box for you to Petersburg-requesting you most earnestly to be so good as to continue \& to send me all the Phaenogamous plants still wanting to my Collection agreeable to my lists sent on.

There is to be sure but too much truth in your observation concerning the great difference of opinion concerning certain Cryptogam. plants-I believe it arises chiefly from this circumstance, that many Botanists, \& especially such as Sprengel (who by the by is rather noted for his superficiality in this respect) do not take the trouble really to investigate closely the specimens sent, but hazard an opinion at first blush without accurate comparison \& examination; which is but too natural considering the minute exam. that is often necessary to be certain of the identity of any moss \&c. I am far from thinking my determinations altogether free from this reproach-However as to the Musci you sent meI took great pains \& wherever I am mistaken-the smallness of the specimens may be an excuse. But I candidly believe that many of Sprengel's determinations ought not to be depended upon 
on account of his inclination to make short work. Dr. Schwägrichen is certainly the more correct \& accurate of the two \& I intend to send to him all those of which I entertain any doubts. Below I shall try to discuss the observations you have made on the particular mosses. I am glad you seem to favor and encourage my undertaking of a Cryptogamic flora. I shall however not proceed to the execution before I have made larger collections \& more accurate observations. Unhappily the death of Muhlenberg deprived me of the advantage of his communications. He had begun \& about half finished a letter to me commenting upon my Musci \& Lichens sent to him-\& all my endeavors to regain possession of the specimens (it was the whole of my then collection, so that I do not know to which species his observations apply) after his death proved unsuccessful. He has a number of Species - to which Swar[t]z is subjoined in his Catalogue [52] of which it seems impossible to know what was meant but by examining his Herbarium-\& a good many new Lichens too which he has named. Finding such to which his specific name might justly be applied I have hazarded to call them by the names found in his Catalogue altho' I have no means of judging whether those I designated thereby are the same with his, in hopes that I shall have an opportunty one day of personally consulting his collection. I should be loth to publish my intended Fl. before I have accomplished this purpose. All my endeavors to gain some knowledge thereof by writing to his son Dr. Muhlenberg \& Z. Collins have hitherto been in vain.

I am particularly obliged to you for your communications concerning Mr. Nuttall \& am extremely happy that he had an opportunity of seeing the plants I sent you. I have lately written to him \& expect his answer. I think Mr. Nuttall's observations uncommonly excellent. His Genera [55] have given me more light than any other book-it is so evident from all his remarks in that work, that they are the fruits of real personal acquaintance with the plants in nature. I am delighted with the prospect of seeing his botanical discoveries published soon-but I sincerely deplore that his cryptog. specimens have been swallowed by that retentive gulph, Mr. Collins, going into whose cave so many footsteps may be traced \& none coming forth! I have among the rest written to $Z$. 
Collins more than once, but have never been blessed with an answer. I am much obliged to you for the promise of Pilularia \& Marsilea.-Could you procure me specimens of Psilotum, Acrostichum aureum, Vittaria, \& Hymenophyllum-I should be very glad indeed. If I can serve you with a good European Specimen of Salvinia natans I shall do so with pleasure.

Mr. Van Vleck wishes me to express to you his sincere thanks for your kind offer to send him plants from your vicinity. In the course of this year I hope to furnish you with spec[imens] of all not yet in your collect[ion] which our vicinity contains. The idea I had of writing a review of the Musci frondos. for Mr. Silliman's Journal [6] I have given up for the present on account of my imperfect knowledge \& the increasing number. (So for instance I have lately discovered a new species of $A n d r[e] a e a$ in great plenty on our mountains which I intended to send you-but forgot it, till the box was closed.) But I am preparing a monography of the genus Viola [68] - which I shall either send to you for Silliman's Journal or else try to get it inserted in the Philosophical Transactions. Is there a prospect that a volume of that work will appear shortly? I ought to do something of the kind to acknowledge the honor done me, by making me a member of that Society. I shall now give you my remarks on your \& Mr. Nuttall's excellent remarks on the plants sent you-very earnestly begging you to continue them-for this is the only right way to acquire accurate knowledge.

Gratiola sphaerocarpa. I cannot think this your neglecta or that must be different from what I conceived it-my sphaero[carpa](tho' to be sure I was doubtful whether it is the plant of Elliott) is nearer virginica \&c. a very large plant-what I took for your neglecta is very small \& somewhat hairy-but I may be mistaken. Lycop[us] exaltatus. I cannot conceive how I came to send you any plant by that name. I have none such-I find the only Lycop. marked as sent you in my list Lycop. angustifolius Ell. p. 26, which is certainly very different from L. europ. (of the latter Mr. Halsey has sent me a spec[imen] exactly like my European). The angus tifol. has an entirely different habit-grows 4 feet high without branching \& looks a little like Leonurus cardiaca.

Cyper[us] uncinatus (C. inflexus Muhl.) is not the Cy. squarros. of 


\section{The Correspondence of Schweinitz and Torrey}

India of which I have a fine specimen-the heads of the latter \& spikes are not I/Io the size-besides other remarkable differences. C. mariscoides-sent you-I now find is altogether misnamed-since I have found the true one which is your Mariscus cyperiformis-I do not know what to make of it, unless it be a Mariscus?

Houst[onia] longiflora-I am very glad to learn that this is the tenuifol. of Nuttall-it is one of our common plants which I neve paid any close attention to \& called it by the name our old botany had given-I should be glad to get the true longiflora.

Phacelia parviflora. Muhlenberg always called this Polemon. dubium-\& I think it suits Pursh's description well enough-but nevertheless it may be a new species. It grows exclusively on the sandy banks of our rivers-but there very common \& in gardens becomes very large $\&$ an inexterminable weed.

$V$ [iola] eriocarpa. I think is not dist[inct] from pub[escens] $\beta$ Nuttall-but certainly from the pubescens of Pursh. It is common here-but the pubescens I never found here.

$V$. ochroleuca is certainly the $V$. striata of Nuttall-but extremely different from what I call $V$. striata Leconte, a species which is common here, but Mr Leconte tells me, that he has never seen it any where else. In my next remittance I hope to send you spec. of all mine.

Thasp $[$ ium $]$ actaeifol[ium]-I have very doubtingly named this plant so-but if not right-it is undoubtedly a new species-our most disting[uished] Umbellate. It frequently grows-Io feet high \& spreads 3 or four wide. It is very common in May.

Sesb[ania] herbacea. I am extremely glad that you point out the true name Trigonella am[ericana] which it is beyond a doubt-I neglected that Genus in examining it-but it suits exactly.

Pray continue your remarks as soon as possible. Now concerning the Cryptog. plants which I named.

Hyp [num] lutescens Schw.-I believe ought to be populeum on reexaminat[ion].

- cupressiforme-The cupressif. is extremely various, it is very possible that this may be incurvat [um].

hians Sw.-This certainly is not the same with plumos[um] Hedw. \& agrees with hians of Muhlenberg, unknown to me. 
oxycladon Sw.-I think I was mistaken in this-\& it probably is really salebros $[u m]$ Sprgl.

contortum Sw.-don't you think this differs from imponens as well as the one I called commutatum which is only a subspecies of filicinum Schwägr.

adnatum Sw. Sprengel calls molle-As I have seen neither besides your Specimen I may well be mistaken-but it appeared to me to suit adnatum very well.

- curvifolium Sw. is certainly not cristacastrensis as you will see at first sight when you come to compare the cristacastr. which I send you-which corresponds perfectly with numbers of European specimens in my collect[ion] \& is one of the most distinct Hypna in nature.

Leskea varia $\mathrm{Sw}$.- this species was so called by Muhlenberg-\& differs materially from $H$. radicale-the $L$. sericea Sw. I believe was a mistake-it may be Neckera cladorrh [izans]-

I am perfectly convinced that the Anoectang $[$ ium $]$ filiforme is specifically distinct fr[om] ciliatum [-] I dont think that Bridel \& Schwägr. ever saw it.

I crave your pardon for the flagrant mistake I committed in calling your Dicranum cerviculatum-D. virens - I must have committed it by a slip of the pen-as it is in my collection by the name of $D$. cerviculatum \& evidently agrees with numerous specimens of this from Europe-while it certainly as you observe, is very different from $D$. virens.

Your J[ungermannia] nodifolia-I think is evidently distinct from J. ciliaris - altho' allied - my barbarously named J. platyphylloidea (by which I wanted to express its near relationship to platyphylla) tho' certainly very near it-I find so regularly distinct by numerous marks recited in my little work that it ought to be separated. $J$. platyphylla both in Europe \& here always inhabits trees \& grows in remarkably arcuately reflected tufts,--platyphylloideaon rocks clothing them of ten to a great extent-\& but slightly reflected or not at all-I confess I have been very negligent in the composition of some of my names. How Sprengel can take what I have called Blasia pusilla-for J. pinguis I cannot conceive. It has no manner of resemblance with that - of which I have this year found the most beautiful specimens in full fructification with 


\section{The Correspondence of Schweinitz And Torrey}

peduncles of 2 inches long, emitted from the side of the leaves. Your specimens were however too imperfect to be certain of its being the Blasia-however they agree very much with fructifying spec[imens] of the latter found by me-\& I think I clearly observed the black male spots in yours - of which Hoffman speaks in his little pocket Flora of Germany [3I], where is a handsome figure. I have had the good fortune this year to find Sphaerocarpus terrestris in the utmost perfection* - \& a new Targionia which I have called orbicularis besides the Targ. hypophylla, which in my little work is not recognised-has since been met with by me. Of all these you shall receive spec[imens]. What I called Thelotrema cinereum may possibly be Pyrenula enteroleuca for I am not acquainted with that genus- \& this Lichen was altogether new to me-but I think it looks much like a Thelotrema. As to Evernia prunastri being Borrera furfuracea you will convince yourself of Sprengel's mistake when you get my Lichen-Both these are so well known to me from their being extremely common in Germany - that I am as certain of being in the right here, as concerning the next. Cetraria lacunosa aut nov-which has not the slightest resemblance with Nephroma papyracea-Sprengel's opinion concerning what I called phyllophora (Cenomyce) on the contrary I believe correct.

The passage of Sprengel's Letter to you, concerning the fungus I in a former letter to you had called Isaria antheriformis-on a slight examination, at first excited my mirth a good deal because I thought it altogether impossible that that could be an hepatic moss. After I had however at the suggestion of your letter submitted this Isaria antheriformis to a renewed examination by the compound Microscope-I have actually convinced myself that Sprengel must be in the right-altho' I cannot conceive how it happens that an Hepatic should be generated in damp paper. There is a complete Thallus or Frons of a texture entirely similar to that of Sphaerocarpus for instance [a rough sketch is inserted here] forming a kind of net work in longitud[inal] meshes - \& the antheriform fructification-assuredly bears a strong affinity to the Horn of an Anthoceros - so that I was affected with something like

* When my little work was written I had not yet seen the ripe capsules, which I since found in plenty. 
Sprengel's laetitia. I had not observed this texture before, \& had indeed not conceived the frons to be an integral part of the specimen-I thought it was the substance on which the presumptive fungus grew. But I am convinced it really is the Blandowia. No fungus has any similar texture, \& there can be no doubt of this frons belonging to the plant, because that texture is perceptible even in the lower part of the fructification.

I am very sorry you could not name all the Crypt. you have sent me-because your names would have undoubtedly been servicable. I must beg you to consider in my determinations of all but the Fungi (in which I pretend to some knowledge) that I cannot be any considerable authority except where I am borne out by my European specimens-as it is only of late that I have applied myself closely to the study. Don't suffer yourself however to be discouraged-exertion \& communication will after a while enable us to be more confident than at present can be the case.

I beg you to excuse my scrawl \& to let me hear from you again as soon as possible, especially concerning the Phaenog. plants I sent you and remain with high respect

Your most obdt Servt

Lewis D v Schweinitz

I should be extremely obliged to you for the whole title of the Species algarum-by Agardh [3] - together with a mention of the price of the work. If you have any means of procuring me a copy I would thank you-\& with pleasure refund all expenses. I have this spring succeeded in determining about 40 kinds or spec. of fresh water algae all of whom except two or three are absolutely the same with the European Species.

\section{TORREY TO SCHWEINITZ}

\section{Dear Sir}

New YORK Oct. 8th I 82 I.

It is now near six months since I had the pleasure of receiving a letter from you, except I must consider as such the single line in the envelope of your Hepaticae. Indeed I can hardly blame you when there was so much apparent reason for thinking I had not used you well. You may depend I was exceedingly 
mortified when on returning to town from the country I found the box which I had given to a person to put on board a Petersburg packet, still remaining in his hands. This was a month ago, \& I hope, that as I then ordered it immediately to be sent, that you have received it safely long before this. I shall be very much dissapointed if it should be lost as there were in it many specimens of which I can not now obtain duplicates. How anxious I am to hear your opinion respecting these plants! Don't punish my neglect by delaying it long. There was a fine parcel of mosses from Massachusetts, some lichens, a few fungi \& some algae.

For your present of a copy of your Hepaticae [74] I feel indebted to you as otherwise I should probably not have seen it until this time, the work not having yet been offered for sale here. I requested you to send me on a number of copies to dispose of on your account but they have never yet come to hand. When shall we have a continuation of this exceedingly desirable \& valuable work. The specimen you have given the world will certainly have the effect of making all lovers of botany wish the complete work-Pray gratify them as soon as possible. You know I will be of all the assistance I can to you in furnishing specimens of such things as come in my way.

You will think me unreasonable to ask any thing more of you after such bountiful collections being sent to me, but really there are so many choice things described in your late work that I cannot refrain from adding a list of a few, any of which will be highly acceptable to me. This is at the end of the letter. How delighted should I be to see that Andreaea you mention in your letter. I did not suspect the genus was in this part of the world. Your monography of the genus Viola [68] I presume you have sent to the Philosophical Society as I have not heard of Silliman's receiving it.

Our Gratiola neglecta turns out to be nothing new after all, for in a letter I lately received from Sir J. E. Smith he remarks, "Gratiola neglecta is precisely the authentic G. virginiana from Kalm. The synonym of Hort. Malabar. belongs to a different plant, considered by Vahl as a variety of G. trifida, but I think it is still more unlike that species"-Now what is to become of $G$. virginica of Elliott? It is undoubtedly a different plant from 
ours as the description in the "Sketch" [22] will show, Shall it be called G. Elliottii?

You ask how Sprengel could mistake what you have called a Blasia pusilla, for Jungermannia pinguis. Smith, in a work recently published by him (Correspondence of Linnaeus [8I*]) has a note on Micheli's Blasia. He says "The accurate observations of Dr. Hooker have proved this plant to be a real Jungermannia, whose calyx \& veil are imbedded in the leaf!" This is taken from the celebrated Monography of British Jungermanniae [33], a work which I have not yet seen, though I hope to do so soon, Mr. Le Conte having imported it from Europe. Now Sprengel being right respecting the genus, will not excuse his naming the species erroneously, J. pinguis \& B. pusilla being little alike. I wish you could have had Hooker's Jungermanniae [33] in time for your Hepaticae [74]. It would have added much to its value to have the synonomy of this distinguished writer.

I am more and more puzzled respecting that little thing Sprengel calls Blandowia as it has so much the appearance of a fungus that I can hardly persuade myself it is not one. The place in which it was found, \& its colour \&c. all make me suspect it will yet be found an Isaria or somthing allied to it. Do you know where Willdenow found his plant? The work which Sprengel quotes is not to be found here- By the way have you determined that other curious little fungus found on moist paper in my herbarium \& which you promised to subject to the microscope? I sent it to Smith, but he has left it unanswered. Do look at it again for it must be somthing curious, Linnaeus would probably call it a minute Lycoperdon.

I am happy it is now in my power to send you the Ist volume of Agardh's Species Algarum [3], which is all that is yet publishedI also send you the Synopsis Alg. Scandinaviae [4] of the same author, \& the Ist fasc. of his Icones Algarum [2]. These are duplicate copies which I lately received \& beg you to accept. You need not think of any return for these, except you may have a couple of copies of your Hepaticae [74] to spare.

* [The copy of this work in the library of the New York Botanical Garden, formerly the property of Dr. David Hosack, has penciled against this footnote (2: II 7), in Torrey's hand: " !(Inform Schweinitz of this)."] 
Mr. Casström of Stockholm sent me the other day a new \& very [ . . * * ] work by Fries of Lund.- Systema mycologicum [23] sistens Fungorum ordines, genera et species huc usque cognitas, quas ad normam methodi naturalis determinavit, disposuit atque descripsit E. F. I82I \&c. The arrangement is totally new \&, I think, much superior to Persoon's. The Ist volume (about half of the work) only is published \& as it has just come to hand I have not had time to examine it much. Have you seen it? If you could be very certain of returning it in two months I would send it to you. It is probable, however, that I shall have another copy ere long, \& if so, you shall have one of the two.

Next Saturday (when a packet sails for Petersburg) I shall send Agardh's books together with some plants which I hope you will be pleased with. My questions respecting the specimens will be put on the labels.

I am exceedingly anxious to procure specimens of American Algae-one set for myself and another for Agardh, with whom I have corresponded several years. Mr. Elliott sent me some lately, which I had not seen before. Have you any duplicates of those you have found near Salem? Can you spare some-

I want some Southern insects very much \& will give in exchange for them European insects, or rare American plants \& minerals - to any extent. Will you find a person to collect for me? I have only room to say I am sincerely yours

JOHN TORREY

P.S. The list of Hepaticae will be inclosed in another letter.

\section{TORREy TO SCHWEINITZ}

Dear Sir

NEw York, Oct. I2th, I 82 I

This day I shall put a collection of plants \& books on board a Petersburgh packet which sails tomorrow. I hope they will reach you soon \& that some of the things may prove acceptable. I wrote you a long letter a few days since in answer to your favour of April last which I had shamefully neglected.

On the next page is a catalogue of the contents of the package on which I have to make a few remarks-. I. The Cryptogamous 

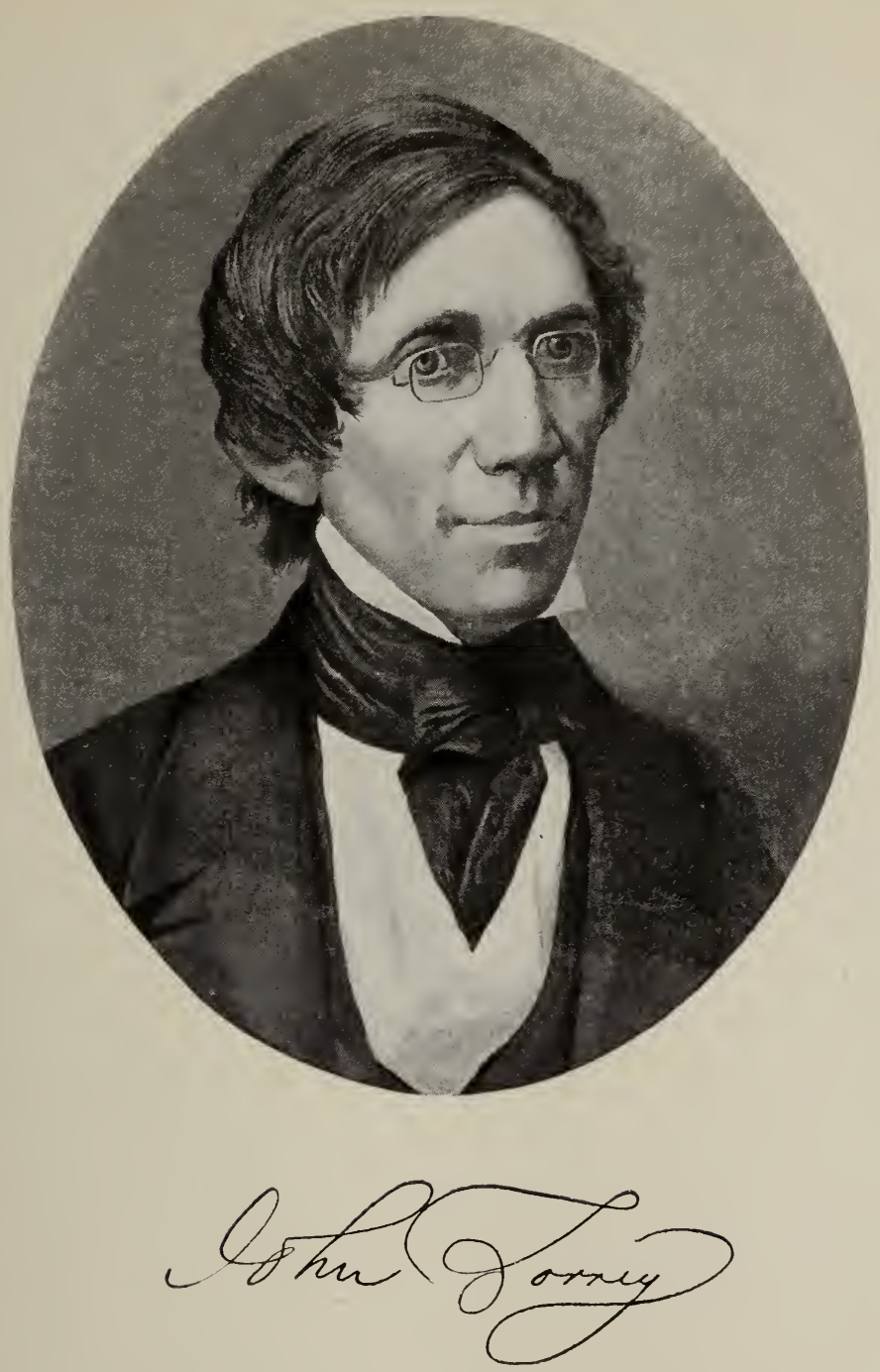

I 796-I 873 

plants from the West Indies. These were collected twelve or fourteen years ago by a Frenchman by the name of Perrin. He brought his unnamed specimens to this city where he died. Dr. Hosack purchased the collection of his wife \& after passing through various hands part of them have come to me. The rest I hope to get ere long. Duplicates of my specimens I sent to Sprengel which he determined and sent me a catalogue of. The names on the specimens I send you are such as he has given.

II. Plants collected by Nuttall on the Arkansas \& Red Rivers in I 819 \& I820. I mentioned to you in a former letter of his being engaged in writing a Flora [54] of the Country he visited. It will soon be finished, \& you will then find all the plants described which I send you. He had not given all of them names when he presented me with specimens. The Marsilea, Pilularia \& Cheilanthes I hope will please you-

III. The North American Cryptogamia are only occasionally named, \& I shall be exceedingly obliged to you for the names of all you are acquainted with or which you can determine without much trouble. Pray don't get out of patience with me for I am conscious I am unreasonable in asking so much. There is a fungus on the Acer rubrum of which I have put up a specimen, which I cannot determine. Do let [here are inserted the lists mentioned, I 38 names] me know its name as soon as possible. The genus is certainly not in Persoon [59].

IV. The few Algae are duplicates from a collection sent me by Agardh \& are named according to his works. Gymnostomum Donianum \& Orthotrichum Lyellii are two rare Scotch mosses.Have you Tayloria splachnoides of Hook. in Brande's Journal [62] [of Science and the Arts]. I can spare you a specimen. It is the Hookeria splachnoides of Schwägrichen.

V. The Phaenogamous plants are principally from the northern States, with the exception of a few collected by Prof. Douglass in the late expedition of Gov. Cass to the sources of the Mississippi. The whole collection was presented to me \& a catalogue of it will appear in the next N[umber of Silliman's*] Journal [9o].

VI. As you mentioned you wished to obtain Agardh's Species Algarum [3] I take the liberty of sending a copy. Perhaps you

* [Words supplied by the editors, the letter being torn.] 
have his synopsis [4] \& Icones [2]. In a little work I lately received from Germany (Jahrbücher der Gewächskunde [40]) is a short paper by Ehrenberg [2I] on three new genera of Fungi, Actinocladium, Campsotrichum \& Enteridium-Are you acquainted with them? Shall I send the book?

Please send your remarks on the plants of this package as soon as you have leisure to examine them. I can hardly ask anything of you until I send something more.

I was going to add some observations on your desiderata which you sent some time since but want of time \& room prevent me-I also find I have lent Mr. Halsey your Hepaticae [74] \& cannot get it in time to make out a list of the species which I want. Pray send me two copies by mail as soon as possible for which I will return money or other books. It is said to be for sale in the Philadelphia book stores but we cannot get anything readily from that city. Do you want Sprengel's Neue Entdeckungen [84] v. I? I think there is a copy to be had here. It contains some valuable remarks on many new \& rare plants, reviews of late works \&c. Has Mr. Halsey sent anything to Mr. Van Vleck? Would it be worth while for me to correspond with him? I think you have put me under so many obligations to you that I shall have enough to do to prepare for you-.

With great respect I remain-Your grateful friend

REvd. L. D. Schweinitz

JOHN TORREY.

\section{Schweinitz to Torrey}

SALEM Oct 29th I 82 I

\section{Dr John TORrey New York}

Dear Sir

It was indeed a pleasure, after rather a long time of anxious expectation to receive your kind letters of the 8 th \& $\mathrm{r} 3$ th of this month at once. They afforded me a scientific feast besides the grateful feelings for what you have so kindly sent me.

I do not entirely however understand, whether the box you put on a Petersburg packet on the I 3 th containing such a variety of invaluable plants, that I can scarcely wait patiently until I see them, is the same with the one you mention as neglected to be sent 
by the person you gave it to containing among the rest about 200 crypt-(Mosses from Massachusetts \&c.). If it is not, I am very sorry to say I have never received that, \& must fear its being lost. I hope you have addressed either if two to Mess. Caldwell \& Orr, Petersburg-

Before I enter upon the rest of the Contents of your highly interesting letters, I must inform you, of a very important change just about taking place in my situation, which tho' it will on the one hand probably render me less useful to you, will on the other enable me to indulge a hope of soon seeing you personally, \& of in future enjoying an easier \& shorter communication with you. I have accepted an appointment at Bethlehem, Northampton County, Pennsylvania \& shall reside there in future, \& expect to leave Salem about the 2oth of November.

In consequence I have sent directions to Petersburg to turn back your package on the way hither, that I may meet it at my future home. It is probable that for some time after my arrival there my avocations of duty will be such as to prevent me from indulging much in my favorite study; but when I shall be enabled to resume it - I shall evidently enjoy considerable advantages from being so near New York \& Philadelphia, more especially in respect of my intended publication. I may flatter myself now likewise with a visit from you to look over my collections (which God speed safely by sea \& land! for I should be in despair if they were lost or injured - they are under way now!) \& will be sure to find out an opportunity of calling upon you as soon as possible. In the mean time I beg to request you to forward anything you kindly communicate to me, from \& after the receipt of these presents to Rev. L. D. v.S. Bethlehem, Northampton County, Pennsylvania-I scarcely know how sufficiently to express to you my thanks concerning the books you are sending \& beg you by all means to send the Systema mycolog. of Fries [23] you mention as soon as you have a duplicate copy-\& likewise Ehrenberg's [paper in the] Jahrbücher [2I] \& Sprengel's Neue Entdeckungen [84]. You are welcome to Specimens of all my hepatics as soon as I shall have time after my arrival. By next mail I shall direct Mr. Gales to send you 2 Copies of my pamphlet [74]. He has informed me that he has forwarded a parcel to New York for sale. I wonder they had not arrived. 
Altho' I shall probably be situated in a less fertile part of the U. S. in Bethl. as to Phaenogamy [see 7o]-I think there is good prospect for Cryptog. there; \& it will be easier to communicate with Mr. Elliott from thence than from here. Besides my friends here lovers of Botany will not fail to furnish me with any thing they can get, in order to supply your wants.

I hope to be able to give you almost a complete set of our Algae aquat[icae] aq[ae] dulcis.- They are however absolutely identical with the European ones. I have pretty diligently \& accurately determined about 55 species-all of them however from the spring of the year, as it is much too dangerous in the fall \& hot summer to be stirring up the mud of swamps \& ponds. I however suspect that a good number may still be discovered later in the season.

Accept my dear Sir the renewed assurance of my grateful respect \& do not scruple I beg of you, to call upon me for anything you wish \& depend upon it, that if it is in my power I shall do my best to oblige you.

My Monography of the Violas [68] is sent to Silliman, who has promised to insert it in the Number of the Journal [6] after the next.

I remain with high respect

Your sincere friend

L D v Schweinitz

Of the Andreaea I have a very great quantity.

By all means preserve for me the Specimen of Hookeria splachnoides you mention. I have been anxious to get it.

[Schweinitz's letter of December 28, I $82 \mathrm{I}$, is missing.]

\section{TORREy to SCHWEINITZ}

\section{Dear Sir}

$$
\text { NEW York Jany. 3I st, I } 822
$$

Your letter of the 28th of last month, I received about a fortnight since. I am much pleased to hear that you safely arrived at your new place of residence where I wish you much happiness. Being now so much nearer together we can communicate specimens \& letters much more speedily \& safely than we could before \& flatters me with the hope that before many months we may see each other face to face. I am very glad that those packages, 
about which I was so concerned have been safely received at last. The part of the package Marked No 5 \& consisting of Phaenogamous plants of the Northern States I have ascertained was by inadvertence left behind. It is safe, however, \& shall be forwarded by the Easton Stage in a very few days. I shall add to it a small parcel from Mr. Halsey which has been lying in my office several months-also Sprengel's Neue Entdeck. [84] \& [the] Jahrbücher der Gewächskunde [40]. If Mr. Halsey has finished using Fries' Syst. mycologicum [23] I [shall] put it in the package for you, hoping it will be returned in about two months. Of Sprengel's book I have another copy, \& beg you will keep the one I send you. I enclose in this letter a specimen of the Tayloria splachnoides of Hooker, which I received from Sprengel. It is a very singular moss, $\&$ an excellent description is given of it in Brande's Journal of the Royal Institution [62], with a much better figure than either Schwägrichen's [66], or that in Bridel's Supplement [12]. It appears to me also that there is very good reason for changing Schleicher's name, as Smith had previously applied the name of Hookeria to the Hypnum lucens. (Pterigophyllum of Bridel). It is surprizing that I should have committed such a mistake respecting the Xyloma acerinum. I was prepossessed with the idea of its being something uncommon, \& was determined to make it so.

With what impatience do I wait to hear from the last package of Cryptogamia I sent you! How long will it be before you will have leisure to examine them? You must not get out of patience with me for giving you so much trouble, \& all I hope is, that some - of the specimens may supply desiderata in your collection. The two copies of your Hepaticae [74] I received safely, in good time. Shall I beg the favour of two more if you have them to spare, $\&$ let me know the price of them that I may remit the money. I want them for my correspondents in Europe. The Cheilanthes collected by Nuttall must be $C$. vestita. I had never seen any species of the genus before this.

On looking over my file of letters, I observe your favour of the 29th of October last has never been answered. I must beg pardon for this carelessness \& say in palliation, that I delayed writing to you until I should hear that you had arrived at Beth- 
lehem, which will excuse me for two months. Does your Monography of the genus Viola [68] embrace all the species of the Northern States, or only those of North Carolina? I wish you would write to Silliman to let me correct the proofsheets, or else attend to it yourself, for he is totally ignorant of Botany \& will make a thousand blunders. That little paper [90] I published in his last No. is full of typographical mistakes \& makes me blush whenever I look at it Dr. Ives promised to overlook the printing, but his. practise is so extensive that he has no time to attend to anything but his profession-There is no other botanist of consequence in New Haven-Will you have any plates? Did you know that Le Conte has long been engaged in writing a Monography of the Violas? He has about 30 species drawn, many of which I think are only varieties. He will never publish anything. You have probably seen him on his way South-if not he will call on you when he returns in April. He will not stay away so long as he used to do, now he is married-His father died the other day, at Newark-

Do not fail, my Dear Sir, to send me those fresh water Algae as soon as you find it convenient, \& also your new Andreaea, which I am very anxious to see.

Since I wrote you last I have.received a letter from Bridel in which there is a catalogue of some mosses I sent him. Of 93 specimens, he considers 33 new species! And in many of his determinations he differs both from yourself \& from SprengelThe following are some of your differences

\section{Bridel}

Schweinitz

No 4 Schistidium subsecundum sp. nov.. Anoectangium filiforme No 58 Cool[ey] Grimmia atrovirens “ “ . . .rthotrichum pumilum Hyp. a Leskea turioniformis “" “. Hypnum hians 50 Cooley \& 5 Dewey. H. curvirostrum sp. nov.

No 8. Dewey. H. serratipilum sp. nov. . No. 70- ead.

- 83 H. curvifolium v. minus piliferum

- 53 Cool[ey]-cupressiforme v. tenuis.

78
-68 -falciforme sp. nov. ...... Leskea varia - 68 - patentissimum sp. nov. . Hypnum radicale 
May I not repeat a question I once asked you-What certainty is there [in the] nomenclature of the lower orders of the Cryptogamia? In the genus Hypnum particularly, I scarcely find two botanists who agree about the name of any of the species. Some months since I sent a large box of mosses to Prof. Hooker the British Muscologist \& when he returns a catalogue of them I shall no doubt find him at variance with most other botanists who have determined them before.

I am now engaged in writing my Flora of the Northern States [89], the first number of which I am preparing for the press. I hope you will assist me to the plants growing in your vicinity. There are many species enumerated in Muhlenberg's Catalogue [52] \& said to be natives of Pennsylvania, which I do not know under his names. I shall send you a list of them soon-

I have only room to express to you the high respect, with which I remain- Dear Sir-Your obliged friend JOHN TORREY

[Schweinitz's lețter of February 25, I 822, is missing.]

\section{Torrey to SchweINITZ}

\section{Dear Sir}

New YoRk. March I8th I822

Two or three days ago I received at my father's house at Greenwich (where I had retired a fortnight for the purpose of arranging my herbarium) a note from an unknown person informing me that he had called repeatedly at my office with a package from you \& had not found me at home. I desired my brother to call for it, but the gentleman was absent. On Saturday night (the day before yesterday) I received another note from the same person, informing me that he would leave town to day for Bethlehem. Yesterday being Sunday I could not prepare any thing for you, but this morning I have put up 35 species of Cryptogamia, \& Sprengel's Neue Entd. [84] with Treviranus \&c. These are added to the Phaenogamous plants which were left out of the last package by mistake. Mr Halsey's little package is also inclosed. I know not whether I shall secure this opportunity or not, but I shall carry the package to town immediately at a venture. I am also as 
yet, ignorant what your package for me contains, though it will doubtless be very interesting I thank you in advance.

I shall write you at greater length by the post, as I must here close for want of time I remain Dear Sir Your much obliged, \& very humble servt

Rev. Mr Schweinitz JOHN TORREY

If I have time this morning when I get to town I will put up for you the work of Fries on Fungi [23] which I beg you to return in a month.

\section{TORREy to SCHWEINITZ}

\section{Dear Sir}

New York, May 3rd, I 822

The last letter which I have received from you is dated Feby. 25. It unaccountably was more than a month in reaching me. I should have answered it before had I not had some hopes of hearing from you on the subject of a package of plants sent you by the hands of a Swedish gentleman a few weeks since. But it [is] now quite time I acknowledged the great obligation I am under to you for the catalogue containing the results of your examination of my specimens. You must not get out of patience if I should trouble you three or four times yet this season. There is no person in this country but yourself with whom I can correspond on the subject of Cryptogamia \& as you have devoted yourself more exclusively to the Fungi, I shall pay the greatest share of my attention to some other branch-probably the mosses. So that my opinion may one of these days have some little weight. You must therefore bear with me, in the hope of my being at some future time of some use in the way of consultation. I need much assistance from such a veteran in science as yourself, for when I work too long alone I begin to get discouraged. I hope the package I sent by the Swedish gentleman (I forget his name Lilsomething [Lilienkron]) reached you safely \& that you will soon have time to examine its contents. I have now some more specimens ready, a few of which are very rare to me. They shall be sent by the first opportunity. I would rather not send by the stage as the men connected with it seem to me very disobliging.

You kindly offer to send me a list of the Cryptogamia of 
your collection but I fear I cannot repay you for the great labour it will cost you. Prof. Silliman has not yet sent me the proofsheets of your monography [68] to correct. You must insist on this being done (if you do it not yourself); for if the press is corrected in New Haven, the paper will be full of errors. Will you please request him to print a few extra copies of it.

Mr. Le Conte arrived here from the South a day or two ago. I informed him of your intention of writing on the Violets, at which he appeared a little disappointed! He will never publish anything in my opinion, as I think I know him well. You have probably seen his beautiful Drawings-but has he not made too many species? With the Southern Violae I am not much acquainted, but there is not one yet found in the Northern States unknown to me \& there are not more than 7 or 8 species. Le Conte makes a great many species of two or three variable kinds growing here.

I am of your opinion respecting Sprengel. He appears to examine specimens much too slightly. He has given the same thing sometimes three different names! Bridel, on the other hand, appears to be too accurate if I may use the expression, for he makes too nice distinctions. No doubt many American species have been confounded with European ones which they much resemble, such as the Climacium americanum \&c., but Bridel has hardly confirmed any of our determinations except when species peculiar to this country were named.

I shall inclose you some remarks on your last return-list if I have time. You will allow me to be candid \& state my objections when we differ in opinion. This is the only way to get at the truth.

A few days ago a friend of mine (the Rev. Ed. Hitchcock of Conway, Mass.) sent me for examination a book of drawings of Fungi 120 in number, done by his wife. I should be very glad to have you look over them, but he wishes the book to be returned by June 4 th next, as that will probably be the only opportunity of sending to him for some months to come. Now if you know of any means of returning them to me by that time if I should send them, please to inform me as soon as possible. I shall send you dried specimens of many of the plants figured.

I am now driving at my Botany of the Northern States [89]. 
shall certainly avail myself of your kind offer of assistance-In the cryptogamia I shall trouble you much. I am very fortunate in having Mr. Nuttall to stay with me, probably for two months. $\mathrm{He}$ is to give a course of lectures here on Botany. We are both bachelors \& he is to stay altogether at my office, so that I promise myself a great treat from the company of this celebrated naturalist. He is much devoted to mineralogy which is a favorite pursuit of mine also. So that we shall have our hands full while he remains.

As you are now settled not a great distance from the place where Muhlenberg resided, you will probably find some of the plants enumerated in his Catalogue [52], which are not to be found here. There are many of his species which are not described under his names in any work that I have seen. Probably some of these are new, but the greater part must now be anticipated by Pursh, Nuttall, \&c., but it would be desirable to know all his species with certainty. Have you any specimens from him? Is there any probability that the long-promised Flora Lancastrensis will ever be published?

May 4th- I perceive, that owing to my Herbarium being in considerable confusion from removing, \& the variety of business I have on hand, that it will be out of my power for a week or two to compare your last list with the specimens to which it refers. This however shall be done as soon as possible.

If I do not hear from you in the course of a week I shall endeavour to have your package forwarded by the stage as you once directed. There will be about Ioo more species of cryptogamia. Do let me hear from you as of ten as possible.

On looking over the collection of Musci you sent me some time since, I perceive that the moss you named Leucodon sciuroides is altogether different from my European specimens as well as from the species you once named as sciuroides for me! It is probably a Leucodon for the teeth, if I am not much mistaken are cleft as in Dicranum, but it is nevertheless what I long ago determined to be Pterogonium intricatum, \& has been so named by Sprengel. Will you look at this again-

With respect,

I remain

The Revd. L. D. Schweinitz

Dear Sir Yours \&c

JOHN TORREY 


\section{SCHWEINITZ TO TORREY}

Dear Sir

Bethlehem May I5th 1822

By last mail (unaccountably late) I had the pleasure of receiving your favor of the $3 \mathrm{~d}$ instant-by which I was among the rest apprised that the short letter which I wrote you immediately after the extremely acceptable receipt of the package brought me by Mr. Lilienkron had not arrived. What can be the reason of so frequent a failure of letters between us, or at least of their delay, while nothing can be more expeditious \& punctual than the arrival at \& from New York of all my business letters? Perhaps I do not sufficiently express your address. In that case-I earnestly beg you to furnish me with a correct one.

The above package, together with the books was, I must therefore repeat, most safely delivered to me by my Swedish friend. You cannot imagine how much I am delighted with Fries [23]-I know I ought to have returned it before this-but unhappily I have been so much occupied with official duties that I have not yet got thro'-but the next opportunity that offersyou may depend on receiving it back-as I hope to compleat my extract in a few days. I most earnestly beseech you to procure the book \& its continuation for me at any price. The system I think very conformable to my own observations.

I hope you are not in earnest when you excuse yourself for troubling me so of ten-no greater pleasure can I receive. I am delighted with the Idea of your devoting yourself to the Musci-\& hope that we jointly shall one day be able to make out something like an Am. Cryptog. The last mosses you sent I have not yet had time to examine with anything like accuracy-but will do so, as soon as possible.

In case you send me anything by the Stage-please to address it to the Care of Mr. Philip Mixsell, Easton-Depend on it I shall send you a list of my Cryptog. collection (designating my authorities) in as short a time as I can.

Prof. Silliman promised to send the Proof sheets to you of my little dissertation on the Violae [68] \& $\&$ I am in despair to hear he has not-for in that case, to judge by the Litchfield Catalog [Brace, II] in the last numbers-there is not the slightest hope 
of it being intelligible. I had mentioned a request to him to have a few extra copies printed-but as his answer did not notice this request I am afraid it may have been neglected. I have only seen a few of Mr. Leconte's drawings of the Violae-I cannot judge therefore of his species-but I am not so little inclined to admit new species as you seem.-A long continued study has perfectly convinced me, that some which you probably only look upon as varieties are really specifically distinct. At this moment they are in full bloom-but to be sure I find none here, about Bethl. but such as are well known-altho' most of the common species here, are entirely different from those in N. Carolina.

By all means I pray you be very strict in your strictures on my nominations-I can hope to arrive at truth only by such. The delay of your last-I am very sorry to say will necessarily deprive me of the enjoyment of the I20 Fungi-because it must be impossible. to return them to you by 4 th June-send me dried specimens however.

The enjoyment you are going to have in living together this summer with Mr. Nuttall I can appreciate, since I had the exquisite pleasure of becoming acquainted with that excellent man at Philadelphia. Be so kind as to present my compliments to him $\&$ to request him to mention once more all the specimens we spoke of, which he would be glad to get from me. I will send them on to you-All my exertions which you may command especially in Crypt. are at your service in the publishing of the No. Am. Bot. [89]-perhaps you would take the trouble to particularize those plants of Muhl. concerning which you want information. I had a great many from him. The Flora Lancastr. I fear will never see the light-nor indeed do I think it would be very valuableas Mr. Conrad tells me he can in many instances not read the text (altogether credible to those who saw Muhl[en]b[er]g's hand).

I believe you are altogether right as to my mistake concerning Leucod[on] sciuroid[es]-sent you by me-I find that by some negligence mixed specim. of Leu. sciur. \& Pterig[onium] intricat [um] are put up in one paper by me in my collection for communication.

In warm hopes of soon hearing from you again \& receiving the 
Ioo Cryp. you announce, \& with a request that you will be so good as to think of the Phaenog. plants I still am in want of I remain

Yours most affectionately

$$
\text { LEWis D v SchWeinitz }
$$

[TORREY's letter of July I6, I 822, is missing.]

\section{SCHWEINITZ TO TORREY}

My dear Sir

BethleheM July 2 Ist I 822

Exquisite would have been the pleasure your kind favor of the I6th instant would have given me, had it not been for the circumstance that you appear not to have received my last letter together with the Volume of Fries [23] which I sent you, the receipt of which is likewise not mentioned. It to be sure contained nothing of any moment, but I should be extremely sorry to hear that so valuable a book had been lost-I entreated you to procure me a copy of it at any price.

I believe it is a good plan to leave a package for me at my friend Mr. Mortimer's-but I am sorry to say I have not yet received that, which you kindly mention. Prof. Dewey at Williams College writes to me, that he has sent a package for me to your care-which please deliver over to Mr. Mortimer likewise when it arrives. I shall write to him on that account. But I must claim your indulgence till winter comes on for a scrutiny of Cryptogamous plants sent me. Then I hope to be disembarrased of the Boarding School superintendence. At present I have hardly leisure to look over Phaenogamous plants-Perhaps you will be able to send me some of those New Yorkers on my list, which you have not yet communicated-\& I should likewise, be extremely glad to get a number of those in Prince's garden which are still wanting to me. The moment I have time I will make out a list of my American deficiencies for you.

I deplore most sincerely that you had not time to subjoin your remarks on my Violae-by all means let me have them as soon as you can. Possibly Mr. Leconte's observation concerning my having made too great a number of species, may be considered just by many-I was guided however by the study of the greater part in nature $\&$ in successive years $-\&$ find, as far as my time 
allowed me, my observations here in Pennsylvania generally to confirm my opinions. The only species which I think admit of further doubts are-whether V. cucullata \& obliqua ought not to be united after all; whether cordifolia be not too near villosa Ell. \& whether repens should be separated from ochrolevica-

Of the rest I am pretty certain. $V$. pubescens common here \& never found in N. C. is extremely different from eriocarpa. Is not the $V$. Selkirkii you mention perhaps related to my punctata from Labrador? The specific difference of $V$. palmata \& asarifolia (the latter never occurs here but is common at Salem) is beyond doubt.

Accept of my best thanks for the curious little moss from Florid[a] \& the highly interesting Roccella from Thule. I conceive however that the Captains who assert this to be the only vegetable there, do not regard crustaceous Lichens as such-for I cannot believe that any rock is utterly devoid of such.

I shall be much obliged to you for the subterraneous fungi from the Coppermine.

Tho' I am almost perfectly ignorant of mineralogy-I read what you communicate on that subject with great interest, as everything concerning natural history is valuable to me. But still I must confess to you, that I am too much of a devoted Botanist, not to feel a little jealous, that the sister science appears to injure Botany by thus withdrawing from it, its most able \& active cultivators like yourself and Mr. Nuttall. I hope however you will no more desert the service of Flora than he for that of Plutus or at least some of his cousins.

The Roccella you so kindly sent me puts me in mind to request you if possible to procure me a specimen of the common Roccella (which I believe may be had in shops-as it is a dyeing article). I have lost the imperfect one I had \& your gift has reinstated the Genus.

Any tropical specimens of whatever kind would likewise be acceptable to me-\& very much so-plants from the South of Europe in which I am very deficient.

With sincere respect \& esteem I remain

Your obdt Servt

LEWis D v SChWEINitz 
Mr. Elliott has sent me his 7 number [22] \& promises to send on No. 8 shortly.

I will just add, secund L D v S, the names of the Violae which I have observed this spring in \& abt Bethlehem.

[Lists 28.]

\section{SChWEINITZ TO TORREy}

Dr. John TORrey New York

BethleheM Nov 24th I 822

\section{Dear Sir}

The uncertainty whether the distressing calamity with which New York was visited, might not prevent a letter from reaching you, hindered me from writing to you sooner; I am now however occupied with examining your last kind packages of Cryptog. \& should on that account have deferred writing still longer in order to give you my determinations, had not the present good opportunity offered for transmitting to you a copy of a small work bearing my name on its title which was sent to me from Germany[75]-to my no small surprize, as I was utterly unaware that it would be published-altho' I must confess myself the author. I left it with a friend some years ago, without any such Idea-but have no objection that he disposed of it in that way. Possibly it will be not uninteresting to you-as it contains a list of all the Fungi I had observed in N. C. previous to 1817 -with descriptions of the new ones \& I beg therefore of you to accept it as a token of friendship.

If you could again favor me with some of the New York-or other American plants still wanting in my collection I should be very much obliged to you.

Do you think there would be any hope of procuring for money or other consideration such plants from Mr. Prince as his garden affords-in dry specimens? I am told he cultivates most of Mr. Nuttall's \& other Missouri plants. If you think it possible I would thank you to point out to me the necessary measures. Prof. Dewey wrote to me some time ago that he was going to send some plants to you for me. If he has, the gentleman who brings this, will be kind enough to take them in return.

In a short time I hope to send you a list of my determinations of your last packages. 
Excuse the great hurry with which I write not having a moment to lose, if I wish to make use of the present opportunity.

Don't forsake Flora altogether for Mineralogy \& Geology, \& believe me with sincere affection

\section{Your most obdt Serv}

L D v SChWEINitz

\section{[A Torrey letter seems missing here.]}

\section{SCIHWEINITZ TO TORREY}

\section{My dear Sir}

Bethlehem December I 8 th 1822

On the two first pages I have given you a list of my determinations of the different numbers of your Cryptogamic plants. Those underlined were new to me, at least in America-those doubly underlined have been named by me. It will scarcely be necessary to remark that it is exclusively the Fungi \& Lichens upon which I conceive you may place dependence as correctly determined. Hepatic mosses but a few only occurred-\& as for the Musci-more especially the Hypna I confess I despair of doing anything satisfactory-without observing them in nature. Some 20 or thirty species of Hypnum may be easily distinguished; the rest I conceive almost mere matters of faith. How it happens that so great a number of the series appear blank I know not-probably you sent me specimens of those numbers-For a dozen or two blanks to be sure, I fear I can account (those however were altogether of little moment) the Papers videlicet perished by one of those sad accidents which married botanists are subject to-under the careful hands of the ladies, who are, you know bitter enemies of all \& everything that can by possibility be attacked with a broom. I most heartily wish that you may derive half as much satisfaction from my determinations as the kind communication of the specimens gave me. You will see what a considerable number form valuable additions to my collection. The whole number of Fungi-seen by me in Am. including those you sent now amount to about I660 species of which I preserve nearly I300. Let me request you kindly to continue your communications \& to command anything in my power. I was delighted with the assurance your last agreeable letter contained, that you 
have again taken Botany in hand. I was almost tempted to publish a counterpart of the Poetical Geology in Silliman-to be entitled the Tears of Flora! describing her despair at the desertion of her votaries but am glad indeed that her own charms have brought yourself \& others back to her shrine. The small packet you lately sent me was peculiarly acceptable as it contained some very interesting new species. I have entered them in the General List, but beg to add a few particular observations.

Botrychium simplex. I hailed with particular joy. Two or three specimens perfectly agreeing with yours had been obtained by me from Canada \& been called by me B. pusillum. Your name is better \& has been adopted.

367 [Rhizomorpha abietina*] is most undoubtedly Rhizomorphabut a new \& distinct species-I should be greatly obliged to you, if you allow me to keep it, as it is in a most interesting state for observing what is considered the Fructification of this Lichen (accord[ing] to Acharius) \& justly I think.

365 [Rhizomorpha crocea]-my Rhiz. crocea in a no less interesting state.

370 [Craterium floriforme] is a most desirable new species of the Genus Craterium of Nees, hitherto containing a sólitary species. This new species forms a remarkable link in the series-which was wanting.

372 [Bartramia an nova] male flowers of a Bartramia or Mniumis this perhaps the true $B$. grandiflora?

374 [Sclerotium radiciforme] comes on a wish!- the third species of a remarkable subdivision of Sclerotium called by Nees Thanatophytum from the destructive effect of the only European Species on the Bulbs of Crocus in France.

366 [Targionia hypophylla?] Without fructificat[ion] I take it for the frons of Targionia hypophylla. What is however the other moss among it with ... . ? [a few words torn out].

I was not a little distressed to hear of the probable loss of the plants sent me by Profes. Dewey. I should greatly deplore that loss-if I did not entertain a hope that they may still be recovered. The package you left at Mr. Mortimer's was received tho' after a very long time-I beg pardon for not acknowledging it in my last.

* [Portions in brackets inserted from the list accompanying this letter.] 
As you so kindly permit me to trouble you with further requests I shall take the liberty of stating to you, what I most eagerly desire to acquire. Any cryplogamous plant determined-\& all undetermined American Cryptog. plants are highly acceptable but equally so all Phaenogamic American plants-not yet in my collection. You will greatly favor me by trying to procure from $\mathrm{Mr}$. Prince, Missouri, Louisiana, or western specimens \& I inclose you a list from Nuttall of the Missouri \&c. which I have not. Next in order come determined European Phaenogamic plants especially from Spain, Italy, France or Greece-\& Graminaceous ones from any part of the world. Lastly exotic plants from tropical countries are highly acceptable, the Filices in equal degree with any others. Having the agreeable prospect before me of enjoying a little more leisure the ensuing year-I shall exert myself to lay in a stock of everything I meet with in order to supply you \& your friends. I can expect to be of service to you only as regards Cryptogamia.

Let me call your attention for a moment to one of the next numbers of the Journal of the Phil. Academy of Nat. Sciences in which you will find a dissertation of mine on two interesting hepatics [72] —of which I can send you specimens. I earnestly beg you may not scruple to demand anything in my power. In the course of next year I hope to have the pleasure of seeing you at New York. I mention to you that in the first weeks of January I shall probably be absent from home; but do not suffer this to induce you to retard sending on anything you may favor me with, as no greater pleasure could be enjoyed by me than to. find large packages waiting for me. If you should happen to see $\mathrm{Mr}$. Leconte please to tell him that I sent a copy of my Carol. Fungi [75] to him by the same opportunity with yours - the receipt of which I am ignorant of.

With sincere esteem

Your Most obdt Friend \& Svt.

L. D v Schweinitz 


\section{TORREy TO SCHWEINITZ}

\section{My Dear Sir}

\section{New York March I 7 th 1823.}

I am ashamed to acknowledge your esteemed favour of December last at this late day. 'The principal reason why I have delayed writing is that I expected to accompany an expedition which was to have set out this spring for the Rocky Mountains. All my time was employed in making preparations, such as packing my plants, arranging papers \&c.-But after all, the Secy. of War has concluded not to send the expedition. Before writing about my own business, however, I will answer your letter. The determinations of my cryptogamic specimens delighted me much, as I was exceedingly anxious to receive them. I regret however to find so many blanks in the list. For those between Nos. 374 $\& 447$ I can account as I passed over a whole hundred in numbering, \& afterwards commenced filling up the chasm-I shall continue filling this up till I get to 447 , \& then proceed regularly from $50+$ where I left off. But before the No. 374 there are 52 scattered blanks, \& these too, respecting specimens I was very anxious to hear about-Many of the blanks I believe are Jungermanniae. You mention some of the specimens having been destroyed by a broom-but that was probably not the cause of the whole loss. But it is useless to regret. I believe I can supply most of the deficiencies from my retained specimens-Indeed, I am confident that I can send you duplicates of many of them.

I am pleased that you agree with me respecting that new little Botrychium. You have before this time, doubtless, seen Mr. Hitchcock's description of the plant in the last No. of Silliman's Journal [30].

No. 374 you observe is a new species of Sclerotium-I am much pleased with this information. as I had determined the fungus to be a Sclerotium \& could not find a description of the species, though I hardly dared to call it new.

No. 366 you suspect to be the Targionia hypophylla-Is it not a Jungermannia? The plants from Prof. Dewey are certainly lost. The loss is as great to me as to you, as there were in the box a great many good things which our friend kindly intended for me. 
In a very few days I shall look over my duplicate West Indian plants, \& select for you such specimens as I have. There may be about a hundred, all of them determined by Sprengel. Of European plants I might possibly send you a few not.in your Herb. Can you send your desiderata? Perhaps I have a few from France. There is a man in Philadelphia who has a large collection of W. Indian plants I am told. You may hear of him from Le Sueur. The paper you published in the Journal of [the] Acad[emy of] Scien[ces of] Philad[elphia] [72] is very interesting $\&$ does you much credit-\& would indeed honor a Hooker. Can you furnish me with specimens of those two rare plants?

As I informed you, I have been much employed this winter in preparing for the intended exped[itio]n you will not expect me to give a very long account of my labours in Botany-I have looked at some things however. The genus Jungermannia has engaged much of my attention. I am gradually describing all the $\mathrm{N}$. American species that come to hand \& making drawings of the new or exclusively indigenous species. Your little book [74] is of great assistance to me but I occasionally differ from you in opinion which I know you have too much frankness to be offended with. I have been studying the splendid work of Hooker on the British Jungermanniae [33]. It is a delightful performance \& I believe very accurate. You did me the favour some time since to send me some specimens of N. American Jungermanniae determined according to your book. There are yet a number of species I: have not in my Herbarium. I should be greatly obliged to you if you would spare me specimens of them. They are as follows
Jung. pallescens
$J$. pauciflora
$J$. resupinata
- irilobata
- connivens
- umbrosa
- reptans
- Ehrhartiana
- quinquedentata
J. exsecta
- bipinnata
- pubescens \&o oblonga

Several of the above I may have, but they are of my own determination \& I should wish to compare them with those thus named by you. I will add two or three other Hepatics in your book, specimens of which are desired by me, viz., Targionia orbicularis, Anthoceros carolinianus \& jungermannoides. My 
collection of foreign Jungermanniae embraces the following species [lists 49].

I know not how I can get along without Weber's work [93]. What is the price of it.-Are there plates? I sent for a copy many months ago, but it has not yet come. Concerning several of your determinations of my Jungermans. I would make a remark or two-No. $32 \mathrm{I}$ you have named $J$. tridenticulata. Will you have the goodness to look at the specimen again. Perhaps I put up by mistake a spm. of $J$. trilobata. My specimens agree with Hooker's plate very well, except the loculi are more numerous in the former. No. 366 "Targionia hypophylla." In the paper from which I took your specm. there appear to be two species. One of them (large \& green) seems to be the Jung. epiphylla, the other (small \& red) is very near $J$. sinuata but still not exactly that. I could not find on it anything like fructification.

No. 325. "J. curvifolia." This seems to be Hooker's plant, \& agrees very well with my European specimens, but I think it different from one that you sent me as $J$. curvifolia.

No. 322. "J. capillaris." Is this the J. trichophylla of Hooker \& others? It looks much like Hooker's pl. 7.

No. 28I. "J. nova." This I have described as a new species, but I have some suspicion that Hooker has it.

No 269. " "J. viticulosa," not so according to Hooker, as there are stipules in that plant, while they are absolutely wanting in mine. I have a little suspicion that it is $J$. asplenioides notwithstanding the leaves are entire. Hooker says the leaves are occasionally entire. I know my specimens are much smaller than the European $J$. asplenioides.

"J. sertularoides." The Linnaean plant is probably J. trichophylla \& J. sertularoides is put as a synonym of that species by Hooker but the American plant is totally distinct. Do you believe the $J$. laciniosa is very distinct from $J$. sertularoides?

I must here close for want of room. Do let me hear from you soon. I had a glimpse of Mr. Halsey a day or two ago when I was much engaged. He had something to communicate from you which I shall go \& hear tomorrow. I returned the other day from Philadelphia, where I spent a fortnight very agreeably with the de- 
lightful scientific society there. I saw Muhlenberg's Her[bariu]m but did not examine the whole of it.

I remain Dear Sir,-your faith \& humb servt.

Rev. L. D. Schweinitz

JOHN TORREY

\section{Schweinitz To Torrey}

Bethlehem April 2d r823

\section{My dear Sir}

Your favor, postmarked the 28th ult., arrived yesterday \& did not fail to give me the most sincere delight, for I had been anxiously expecting to hear from you, \& had begun a letter which I now lay aside in order to answer yours. Greatly as I deplore that you have been disappointed in the Expedition to the Rocky mountains which must have produced to Science, yourself, \& I flatter myself to me, such a harvest, I am still glad to know you are in our vicinity \& that I shall have a chance of seeing you, in case I succeed in my design of coming to New York on a visit. But I most sincerely wish you could make it possible to come hither \& spend some weeks with us - in which case my collections would ensure to you at least some entertainment. I am very glad to hear that my attempts to determine your kind communications were agreeable-but greatly regret that, excepting Fungi, in which family I can assume a little authority, they are so little to be depended upon. I think you misunderstood a part of my letter-I do not believe that either broom or other enemy of Science actually deprived me of anything I received from you. It was only the labels or papers whereon I had marked your numbers \& my determinations, which were partly swept away \& I had neglected to mark your numbers in my Herbarium, whither I had before the Catastrophe arranged your presents. After all I was not aware of the nature of your numbers \& imagined they had no relation to what you sent me, but refered to your own collection. I shall take care in future to be extremely particular in noting down whatever you mark on the papers \& labels immediately. Mr. Nuttall promises to send me shortly all his Cryptog. for examinationwhich I hope he may do.-I am greatly grieved at the loss of Prof. Dewey's plants - but intend to write to him for a renewal if possible. You will most signally oblige me by sending West Indian or indeed 
any plants you can spare or procure- $\&$ as a method of enabling you in some measure to judge what would be particularly acceptable of European plants I shall take the liberty to pack up with those you have desired in your letter (mentioned below) my Catalogue of Herbar[ium] \& those wanting, having just made a new copy - tho' I fear you will not be able to read my Scrawl. Perhaps it may afford you an opportunity to send for this \& that you might wish to have-I promise to keep back nothing of which I have duplicates. Mr. Nuttall gave me information concerning the Collection of Cuba plants you allude to-but I $2 \$$ per hundred those extremely badly preserved-exceeds my finances. I enclose to you this time a general list of my desiderata in Am. Phaenogamy with a particular request to procure as many of them as possible either from collections, or from Prince's Garden. I would go to some expence to get them. Is there no possibility of procuring any of the plants that Dr. James brought in the last expedition? American plants I value at least treble others-because my collection is already so considerable. You are a happy man in having succeeded to get at least a glimpse of Muhlenberg's Herbar.which I have several times vainly tried to get at. Is the Cryptog. part so arranged as to afford an opportunity of looking it over? It will be absolutely necessary to do so as to the Lichens, because Muhl. Cat. [52] contains a number of names nowhere else occurring.

I was very much delighted with your zealous labor on the Hepatics \& will with pleasure afford you all the aid in my powerAccording to the French adage-highly respected by me, \& which ought to be the motto of all naturalists "qu'une erreur découvert vaut toujours une vérité trouvée."

I am so far from being offended with any difference of opinion on such subjects, that I rather am inclined to forego mine very easily, especially where I am conscious of a want of knowledge. I should therefore be very glad to have your opinion especially where it differs from mine. Sometimes I suspect however this difference will arise from my having made a mistake in the reference. As to the Jungermannias you have the decided advantage over me of possessing Hooker [33] (the very sight of which at Mr Collins, gave me the greatest delight) \& I should in every case bow to de- 
cisions drawn from him. Weber's [93] is but an epitome, a small work of pages-without plates. In order to enable you to judge of what might be useful to you I insert a list of all my hepatics. $\mathrm{xx}$ prefixed signifies that I have specimens both from Europe \& America, $x$ from Europe, - tropical, \& underlined-such as I have undertaken to name-several of which are not in my little book [74]. The sign + shews when added behind, that I would be able to spare specimens tho not always such as are in fructification. Those unmarked are American. [Lists I2I].

Of the American Jungerm. \&c. you mention I am putting up for you specimens of the following immediately. I. trilobata 2. connivens 3. resupinata 4. umbrosa 5. quinquedentata 6 . bipinnata 7 . pubescens Of pallescens I have no duplicate- of reptans no American specimen at all, pauciflora is a Labrador species without a duplicateEhrhartiana I have too little of, which I fear is the case with oblonga likewise-but that I will try to send. To these I add Targionia hypophylla, Anthoceros carolin[ianus]_\& a small bit of Ant. jungermannoides not having any larger-as well as my Sphaerocarpus \& Carpobolus of which as published in the Journal of the Phil. Academy [72] you have taken so flattering a notice.

The following species among your foreign ones-I should be glad to get: J. Baueri S. J. curta S. J. deflexa S. J. fissa Curtis, J. polyanthos T. J. varia S.

Concerning your remarks to my determinations of your Junger. I observe that No. 32 I tridenticulata-may probably belong to trilobata-I think the two otherwise very distinct in habit. What I call trident [iculata] Mx.--is short \& branches almost at right angles. As to 366 Targionia hypop $[$ hylla] I judged merely from the Thallus - the good fructiferous Salem specimen I intend to send, will enable you to decide. 322. J. capillaris is to be sure very near the German trichophylla-but still would probably be found to differ specifically.-The viticulosa of Weber-to which I arranged your No 269 -is represented by him without Stipules.-My J. laciniosa from Canada differs materially both in size \& habit from sertularoides-which is certainly very diff. from trichophylla. Let me, if you please, know shortly which of the foregoing list of my Jung. besides those above mentioned I shall send you \& I will directly make up a little packet. 
At the same time let me know, if you are in possession of Hedwig's Species Muscorum Frondosorum, Opus Posthum. a Frd. Schwägrichen editum in quarto with 72 Plates [29]-I have chance of procuring it here for the very cheap price of io Dollars (at least I think it cheap) \& perhaps might get it for $8 \$$. If you, or any of your friends would wish to have it I will get it, and send it on.

Forgive me for troubling you at such length \& if you can without inconvenience let me soon hear from you.

I remain with sincere regard

Your most obdt Servt

LEwis D v SCHWEINITZ

P.S. I am preparing to go largely into the Fungi this year \& possibly reattempt the Algae aquat.

\section{Torrey to SCHWEINITZ}

My Dear Sir,

NEw York, April II th, I 823.

I received a few days since your very acceptable letter of the 2 nd inst. There is indeed no probability that an expedition will be sent to the Rocky Mountains this season \& I have resolved to make myself contented here. It will be in the highest degree agreeable to me to see you in New York should you make a visit in this quarter, but you will doubtless be much disappointed in finding anything worth your notice among us. After being in Philadelphia, New York will appear to great disadvantage. You will, however, see our good friend Mr. Halsey, who beside myself, is the only botanist here! If you are fond of Mineralogy there are many collections among us that you would perhaps be pleased to see. Whether it will be in my power to make a visit to Bethlehem this season, will depend on my not being engaged in more important avocations in July \& August next, which was the time I had appointed to spend a few weeks in traveling. At any rate, while I am engaged in Botany you may depend I shall never forget a friend whose acquaintance has offered me so much pleasure as yourse.f.

By a friend who goes to Philadelphia in a day or two, I shall send, to the care of J. \& A. Ritter of Phila. a small package 
of specimens I have just sealed up for you. If, however, I should hear from Mr. Halsey of a better opportunity of sending to you, I shall alter the direction of the package. The contents are as follows-

I. About forty specimens of American Jungermanniae. These are not all named being, sent for the purpose of obtaining your opinion respecting them.

2. Five specimens of European Jungermanniae, being those from my Herb. of which you desired specimens-except J. curta which will not bear dividing.

3. Twelve specimens (principally of grasses) from the collection made by Dr. James in the Expedition under Maj. Long. These are the only duplicates there were. Wherever there were two specimens I took one for you. I beg you will examine them particularly \& give me your opinion respecting them.

4. About thirty specimens of West Indian plants from Perrin's Herbarium, of which I gave you a history when I sent some Cryptogamia from it some time ago.

I regret that it is not in my power to send more by the present opportunity as I can only devote a part of my time to the pursuits of science. In the course of a few weeks I expect to have the pleasure of forwarding another package, in which I flatter myself you will find some things interesting to you.

Your list of desiderata in American Phaenogamia is a formidable one, but I will do all in [my] power to make it less so. You must be aware, however, that in supplying your deficiencies from the South, I can be of little use to you except of such plants as Mr. Prince cultivates at Flushing. In Northern plants I can do more for you, though among these there are not a great many you do not possess. But, after all, I fear there are not a few in your catalogue, which neither of us will ever see. There are [a] great many obscure \& doubtful things in these books, which I strongly suspect are old acquaintances in disguise. On these I shall make some observations in a future etter.

You enquire whether there is any possibility of procuring specimens of the plants collected by. Dr. James in Long's Expden. I answer, that you may get a few through me if you will wait a little patiently. Dr. James is now in this city \& has all his plants 
with him. There are very few duplicates except. of the little rarities he collected on the highest parts of the Rocky Mts. Dr. $\mathrm{J}$. has placed the collection in the hands of his brother here, who has orders to deliver me the whole, should the Doctor not return in one year (he being on the point of starting for the Missouri), or should any accident happen to him in that time. Now as he says himself, there is little probability of his returning to New York within three years, I expect to possess this unique collection, when you may depend on sharing the duplicates with one or two choice friends. I have already taken a dozen of the little things from the snowy regions of the mountains \& have determined some of them satisfactorily. Among them are two decidedly new species of Androsace, Rumex digynus very small \& with but two stamens! Adoxa moschatellina-or a n. sp. very nearly allied to it, \&c. It is my intention to present this boquet to some of our societies for publication.

I did not particularly examine the Cryptogamia in Muhlenberg's Herbm. my attention being particularly directed to the grasses \& Carices. I believe the lichens are in a good state for examination-The Algae are very numerous but few of them are determined. I believe I mentioned to you that all (or nearly all) the Lichens marked n.sp. in Muhlenberg' Catalogue [52] are described in Acharius' last work-his Synop. Meth. Lichenum [I].

Your list of Jungermanniae, is very respectable but I regret that of those which [are] most desired by me, there are no duplicates. However of those which you have so kindly offered to me, I take the liberty of selecting the following which would be valuable additions to my Herbarium [cites Io]. As you receive specimens of which you now have no duplicates, I beg you will remember me.

Is there more than one edition of Hedwig's Species Muscorum, by Schwägrichen [29]? Do you allude to Schwägri[chen,] Sp. Musc. which is only called an edition of Hedwig by the modest author? Whether it be this or not we need the book here, \& I have persuaded our Lyceum to purchase it, as I am too poor myself, provided it can be obtained for $\$ 8$. If you should not be able to get it for this sum, I will add two dollars myself, \& send you 
the money as soon as I hear from you that the book may be obtained.*

Our Lyceum is in a pretty flourishing state, but we need patronage greatly. If we had a Maclure among us we could do a great dea. I wish you would send us papers-could you not give us something on the cryptogamia?

I had nearly forgot to mention, that among the plants of Perrin is a specimen of a shrub Sprengel has nicknamed Torreya. I luckily found a duplicate which I beg you will accept of as an evidence of my particular esteem. I wish you would examine it attentively \& give me your opinion respecting its novelty. This plant forms one of a Hexade which Sprengel has described in detail \& sent to me to be published in one of our Journals. It is accompanied by most elegant drawings of each species by his Son. I will send you shortly a copy of the figure of TorreyaWith renewed assurances of my sincere esteem-

Rev. L. D. Schweinitz

I remain-Dear Sir-

Your obed \& humble servt

JOHN TORREY

Schiweinitz to Torrey

My dear Sir

Bethlehem May the 25th 1823

This evening Mr. Jacobson of Nazareth, an intimate friend of mine, is going to start for New York. I make use of his polite offer to send you the work of Schwägrichen [29] for which according to your direction I have paid ro Dollars. If you would be so good on receipt of this to call upon Rev. Benj. Mortimer, Fulton Street, you will there either find the gentleman or at least the packet - as I was unable to give him such directions as would enable him to find you, he being a perfect stranger at New York. As he intends to return in a few days it would perhaps be a good opportunity to send me a package if you have any ready. $\mathrm{Mr}$. Dewey has just informed me by letter that he has forwarded one for me to your address. Inside the book you will find my old copy of Index of my Herbarium-thinking it might enable you to point out things which I possibly have in duplicate as

* Since writing the above I have concluded you mean Hedw. Sp. Musc. opus posthum editum. Schw. Lipsic. I80I [29]. 
acceptable to you-which would be instar a command to send them. Besides you will there find (miserable specimen I fear) the Jungerm. you requested in your last. That kind \& precious letter arrived here during my absence from home-while I had the good fortune to receive the plants you last sent on my journey at Philad. \& enjoyed them greatly. I have since delayed answering from an anxious desire to give you my opinion on the Jungerm. sent. Unfortunately my time has been so taken up by urgent duties, that I have not succeeded in finishing their examination. They appear, most of them, to be such as I had seen before-but I shall beg leave, after a while [to] communicate my remarks.

My hopes of seeing you at New York this season are nearly vanished as I shall be under the necessity of making a journey of business to Muskingum in July. Possibly this may however result in the acquisition of a good number of Western plants, as I propose traveling in a manner that will permit botanizing.

I think it needless to repeat how very much I am obliged to you for all your kindness \& more especially for the last package. During my stay at Philad. Mr. Say gave me some hopes that you would still join the expedition of Mjr. Long-but I am sorry to have heard nothing further. In my next-excuse my hurrythey are calling me in ten directions-I hope to give you some satisfaction upon the several points your last favor mentions \& mean while remain

Yours sincerely

Lewis D v Schweinitz

\section{Torrey to SchWeINitz}

[No Date. Perhaps the letter of September Io, I823, referred Dear Sir

to in the following]

I was sorry to learn this afternoon that your friend Mr. Kummer leaves town early tomorrow morning, as I cannot get ready for this opportunity, a package which I hope will be acceptable to you. Not willing, however, to send Mr. K. empty away I send by him a copy of the Ist Volume of Agardh's Species Algarum [3] which I a few hours since received from Sweden. Also a copy of the Ist No. of my Flora [89] which I beg you will accept as 
an evidence of my esteem. In a few days you may expect another package by the stage in which is the $\$$ IO. for Schwägrichen [66] \&c.-

In great haste, I am \&c.-

TORREy to SCHWEINITZ
Yours truly

JOHN TORREY

\section{My Dear Sir-}

NEw York. Sept. I I th, I 823.

I forgot, in my hurry yesterday, to request your opinion on a subject to which I beg you will answer me immediately. I I have occupied most of my leisure time, during several days past, in examining a very interesting grass collected by Dr. James during the expedition under Maj. Long. After I had finished my description and drawing, which I prepared for publication in the Ist No. of the Annals of the New Lyceum [88*], I began to suspect my grass was not new, \& I have therefore stopped the press while I hear from you on the subject. If I mistake not a specimen was sent you some time since, labelled-“"Herb. James. No. 9," but lest this should not be the case I inclose you some of the flowerswith a rough sketch of the plant [†] which I hope will be sufficient for you to make up your opinion respecting it-

The flowers are spiked \& heterogamous-Spikelets 3 at each joint of the rachis, sessile, surrounded at the base by a villous involucrum. Central spikelet hermaphrodite, I-flowered. Calyx 2-glumed, glumes orbiculate, 2-cleft, 5-bristled between the divisions. Cor. 2-valved, hyaline; inferior valve with a short bristle at the top. Lateral spikelets male. Calyx 2-glumed, 2 -flowered inferior glumes with a bristle on one side below the middle. Corolla 2-valved, unarmed.

By dissecting the inclosed congeries of spikelets you will see whether I am right in my dissections \& description. The genus to which I fear my grass belongs (for I hoped it was a new genus) ** is Aegopogon of Humb. E Bonp., but it differs from that, which has the spikelets pedicellate, corolla with the inferior valve 3-

* [For a sketch of the organization of the Lyceum and its subsequent history see Barnhart, J. H. The first hundred years of the New York Academy of Sciences. Scientific Monthly 5: 463-475. November, I9I7.]

$\dagger$ [See FIG. I, on next page.]

** [Torrey described this as a new genus, Pleuraphis, the next year, the type species being $P$. Jamesii, Ann. Lyc. N. Y. 1: I48, pl. Io. I824.] 
The Correspondence of Schweinitz and Torrey 181

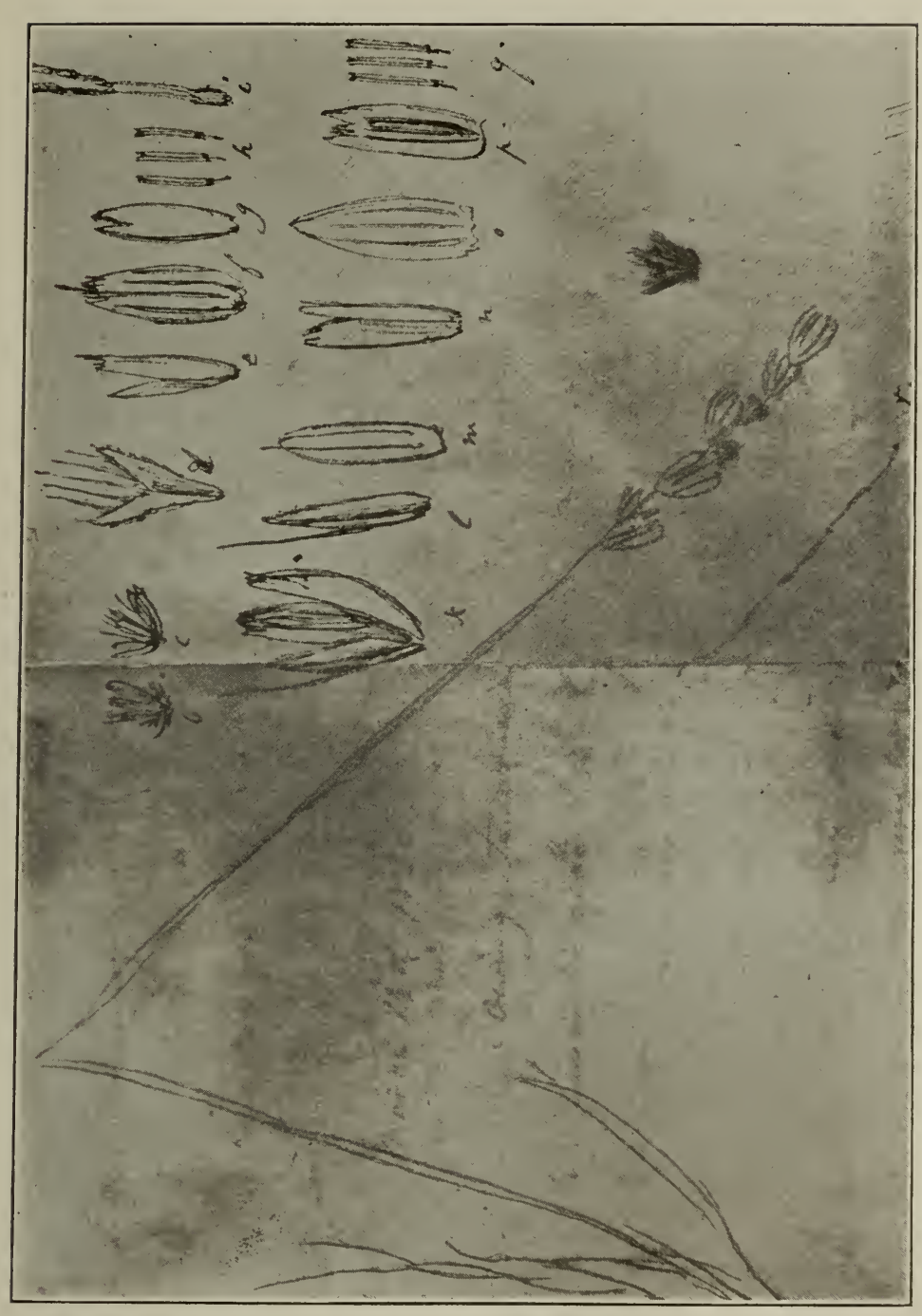

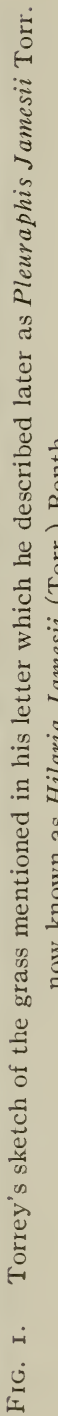


awned \& the superior 2-awned-the male spikelet resembling the hermaphrodite one except in the pistil \&c.

From Amphipogon of $R$. Brown it differs in not having a spiked panicle, in the exterior florets of the spikelets not having an involucrum, \&c.-

From the genus Lycurus of Humb., which has the spikelets geminate, one of them $\bar{q}$, pedicellate, the other $\sigma^{7}$ v. n., subsessile \& resembling the hermaph. though smaller \&c.-
A. a sketch of the plant
b. congeries of spikelets

c. the same expanded to show them more distinctly

d. a glume of the hermaphrodite spikelet

e. corolla of the same

f. _- inferior valve

g. superior valve

h. stamens

i. pistil k. spikelet of male florets-

1. inferior glume-showing one of the margins involute \& armed with a bristle about half way down

m. superior glume-one of the nerves produced into a cusp

n. corolla

o. inferior valve

p. superior valve

q. stamens

r. rachis-

Aegopogon cenchroides of H. \& B. comes near our plant by the description but yet differs sufficiently to be at least specifically distinct. To the other species of this genus (several of which are described by Lagasca in his Nov. Gen. \& Sp. [42][ under] the gen. name of Hymenothecium) it has little affinity.

I have no time at present to write more, except to ask whether you have a short paper that we could publish in the present no. of the Annals of the Lyceum, a work which I think I told you we were about commencing-If you have one that would occupy 4 or 5 pages or less we would be much obliged to you for it \& Please-answer me by the return post if possible $\&$ believe me to remain

\section{Dear Sir}

Your much obliged humble servt \& friend JOHN TORREY

P.S. I am preparing a package for you to go by the stage in a few days. Mr. Halsey hopes to be able to add something. 
The Correspondence of Schweinitz and Torrey 183

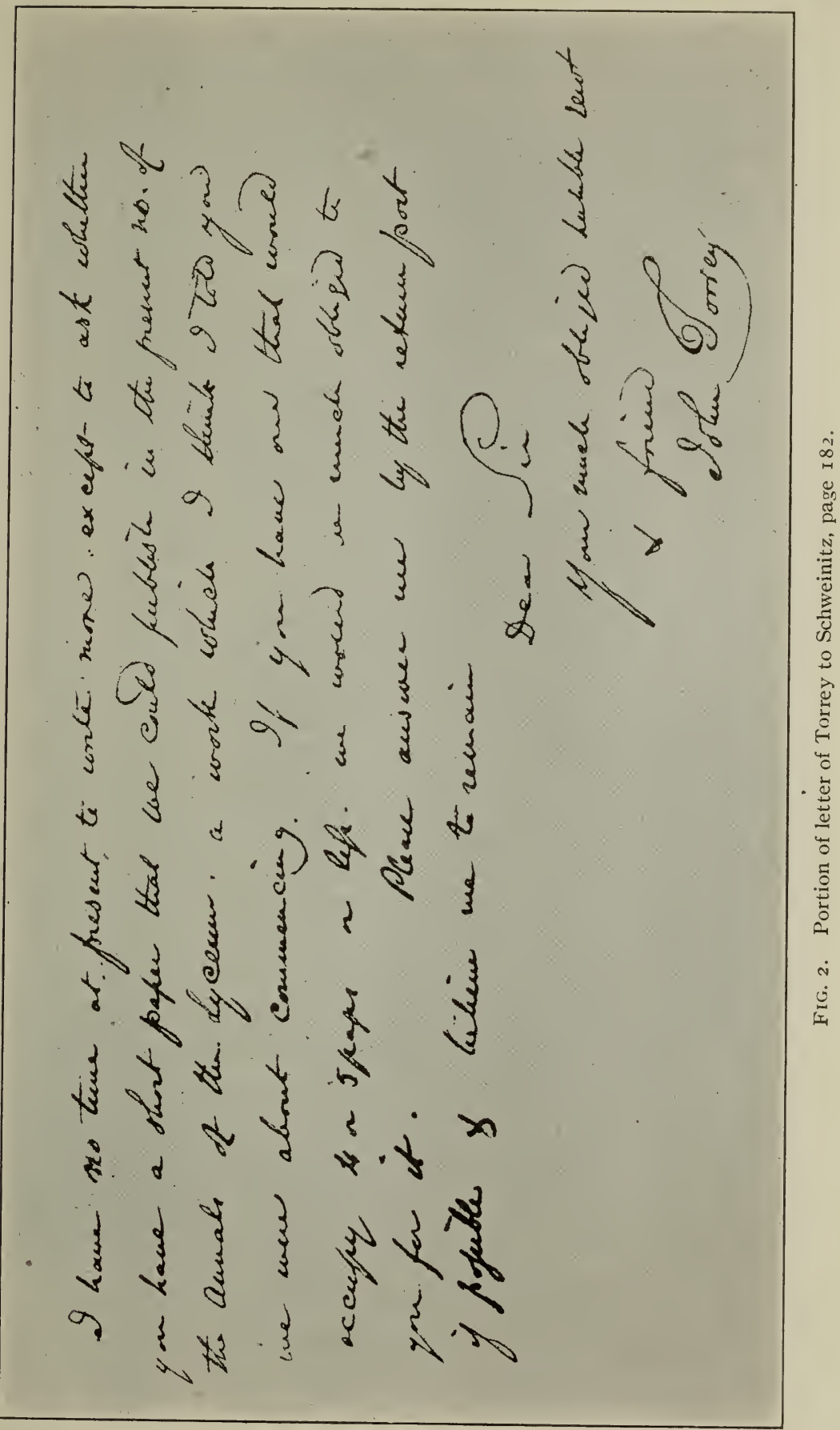




\section{SChWEINITZ TO TORREy}

\section{My dear Sir}

Bethlehem Sept. I6th I 823

This moment I receive your kind letter of the IIth \& am the more eager to answer it immediately because I greatly regret that you took the trouble to apply to me, upon a doubt, which I am so entirely incompetent to decide, as it retarded your work. I have never paid anything like sufficient attention to the analysis of the Grasses (the Carices excepted) to enable me to give an opinion; least of all concerning the identity of [a] Genus-it is a part of the Study of Botany which I have still in view-Besides I am unprovided with the works in which the genera are analysed. Excuse me therefore in not being able to be of any service to you in this respect. Neither of the Genera to which your interesting grass (of which you certainly kindly sent me a specimen) might belong is at all known to me.

My long absence has prevented me from writing the little articles which I had intended-I hope to be able to prepare some during the winter-with which I shall trouble you for the Annals of the Lyceum if found worthy. I am at this moment busily engaged with my monography of the American carices [7I], which however becomes too voluminous to be printed in a Journal. I shall therefore, if you permit me, take the liberty, when finished to send you the manuscript, together with my Volume of Carices for use \& inspection-especially in reference to your Flora [89]. I cannot describe the pleasure which its perusal gave me, nor sufficiently thank you for the present. Unless you forbid me, my next will contain a sheet of remarks upon it* - together with the few additional plants if any, which I have found in the region it includes-I intend to subjoin a list of the plants in this vicinity to enable you to send for any you may wish to see for your workif I have no specimens to spare I wish you at least to see such as may be of use- \& there is not one in my collection which I should not be glad to send you for examination \& recognition.

It will not be uninteresting to you to be informed that the Gerardia auriculata - hitherto only found by Dr. Darlington in Chester

* Not upon the Genera of Grasses however-for unfortunately I have only a kind of knack-knowledge of them. 
county, has this year been found in quantities by the young students at Nazareth. Specimens are at your command. It is not a Seymeria - as Nuttall supposes. Apropos, the Seymeria macrophylla I found rarely on the Muskingum river during my Journey.

The receipt of Prof. Dewey's Carices [I9] gave me inexpressible pleasure $\&$ has been of great use to me in my present work. I most eagerly expect the package you promise. Please to let me hear from you as soon as convenient \& believe me, with great gratitude for your valuable presents, Your humble servt \& sincere friend

\section{D v Schweinitz}

P.S. How is it, that Elliott's numbers [22] do not appear? He wrote me that three would be forthcoming in May.

Would not a comparison of the Asters \& Solidagines in my collection, with yours, be a good assistance when you come to that part of the business in the Flora [89]-You are welcome to consult my stores-as we are not so far distant from one another as to prevent my sending my whole collection to you \& I think nothing more useful than such comparisons.

\section{Schweinitz to Torrey}

My dear Sir

BETH. Sept. 2 Ist I 823

I take the liberty to enclose [*] you this day my very unimportant remarks upon your excellent Flora [89]—do me the favor to let me know your sentiment upon them.

I have almost completed my Monography of the Carices [7I], of which I intend to make a Copy as soon as possible-in as good writing as my unlucky hand permits, to present to you in manuscript. But I wish to make an enquiry concerning the Journal of the Lyceum-my head almost runs crazy with the astonishing effects of a perfectly new (at least to me) analytical method of distinguishing the plants of a numerous genus, by analytical tables, which if well executed, cannot fail of determining the species. The idea was I believe first operated upon by De Candolle \& Lamarck\& I have just received a Flora of Northern Germany by one of my most intimate friends there, Mr. Peter Cürie [I7]- in which that plan is pursued thro out-I instantly applied it to our Carices,

* [The enclosure is printed at the end of this letter.] 
\& find it answers admirably. Now my enquiry is, whether your Journal would admit such an analytical table [67] of all the American Carices-about Ioo in number which I know of-by means of which every person that is only slightly acquainted with the terminology - shall be almost with absolute certainty enabled to find, of any given Carex in his hand, whether it is in the table or not, $\&$ if in, what name the author of the table calls it by. These names will then refer to the authors who mention the Carex for ample descriptions-or, as regards the new ones established by me, to descriptions, which might follow in another number. The table itself would not take more than at most five leaves in an octavo book-If you are unacquainted with this method, I am sure its effects will please \& astonish you. In case you thought such a table admissible (with short directions for its use) what would be the latest period for sending it to you?

Let me beg you, when you put the promised package of plants into the stage, to give me information thereof at the same time by way of Philad.- -with a few lines, that I may enquire for the package at Easton-

With sincere affection

Your most obliged Servt

LEWIS D V SCHWEINITZ

REMARKS UPON DR. TORREY'S FIRST NUMBER OF A NORTHERN FLORA

The plan and its execution are equally excellent. As regards its coincidence with Elliott's Sketch and Nuttall's promised Western Flora to form a complete account of the plants of the United States-I only regret that Mr. Elliott has confined himself to South Carolina \& Georgia. The two intermediate states, Virginia \& North Carolina, more especially the latter with its high mountains \& remarkable swamps, leave a gap of some consequence, which ought to be filled up. I presume Dr. Torrey does not include Labrador, Canada, etc.

I shall now proceed to remark upon the Genera \& species in their Order; not mentioning those I have nothing to say to.

Salicornia herbacea or virginica; of these I have never seen specimens \& beg for some. 
Hippuris vulgaris. I have American spec. only from Labrador-\& these are altogether identical with numerous European specimens-so that I do not believe in the existence of another Am. species.

Callitriche verna $\beta$ intermedia. I believe to be the same with heterophylla Pursh-but think the latter name more appropriate.

linearis Pursh which I have found in N. Carol. rarely$\&$ had beautiful fructiferous specimens from Cherokee Country - is not at all the same with C. autumnalis of Europe. The autumnalis of Europe is certainly different I think from linearis - I can send you specimens of both-which tend to prove it.

terrestris. I have much doubted the specific difference of this from heterophylla-since I observed a spot, where the heterophylla was floating, dry off \& exhibit undoubted terrestris, shortly after, on its dry surface.

Blitum; all the spec., as American, are unknown to me \& desirable, especially maritimum - as I have spec. from Europe of the others.

Ornus. I wonder by what means one could get at this fabulous tree.

Veronica Beccabunga. I have found in Ohio-exactly the European-what is here called anagallis is certainly not the true European one-I have called it intermedia var.

Veronica reniformis Raf. cannot scarcely be different from arvensis. Gratiola virginica. Taking the neglecta for the true Linnean virginica, that of Elliott, which is manifestly distinct-\& has been found by me here at Beth. - \& by Capt. Leconte on Schooley's mountain [New Jersey] ought to. be distinguished by another name-perhaps Elliotti-\& inserted. Have you no Northern specimens?

megalocarpa.- greatly desired-

Lindernia dilatata you say is much rarer than attenuata. The latter I have never found in Pennsylvania. The former is in great plenty on the shores of the Susquehannah-Harris$\mathrm{b}[\mathrm{ur}] \mathrm{g}$.

Catalpa. With your leave-is not the word south in the Hab. a misprint for north? 
Justicia pedunculosa. Capt. Leconte maintains that the southern pedunculosa (which I have never seen) is very different from this-which is very common on the Susquehannah at Harris$\mathrm{b}[\mathrm{urg}]$, found in full flower beginning of July, $\mathrm{I} 823$.

Utricularia setacea-our Salem N. C. specimens are most generally 2-flowered.

Utricularia purpurea-I long to see.

Lycopus Europaeus $\beta$ angustifol. Do you really think that the Lycopus europaeus which you kindly sent me, \& which grows here plentifully-is the same plant with L. angustifolius? This I have never found branching, or at least only at the base, \& then it sends up long stalks often 4 or more feet high, with leaves all alike. The europaeus you sent me is certainly not different from the European specimens. I found a very curious tall branching one on the Muskingum which agrees very well with Elliott's sinuatus - \& European specimens of exaltatus-\& differs entirely from europaeus.

I have no doubt the L. uniflorus of Muhlenberg is not a separate species-possibly the Canadian plant of $\mathrm{Mx}$. may be different.

Monarda didyma; of this I found fine specimens in Ohio very near the Pennsylv. line -and most splendid ones of Pursh's Kalmiana branching exceedingly on the Laurel mountain, Pennsylv. I agree with you that there is no specific difference.

The $M$. punctata so extremely common in N. C. I have not met with here, the $M$. hirsuta is found on the Allegany mountains. The latter is called Horse mint in Ohio, where it is a great nuisance in wheat and rye fields, communicating its taste \& smell to the grains.

Salvia Claytoni-have you seen that plant? \& where can it be got? Circaea lutetiana $\beta$ canadensis. I have not seen here-it is rare in N. Carol. but common on the west side of the mountains in Penns. \& Ohio.-The species which grows here plentifully is the $C$. intermedia of the German botanists - to be sure the specific difference is not great \& consists in cordate opake leaves-\& smoothness-After all I think there are but two real spec. C. lutetiana $\&$ C. alpina. 
Lemna minor-you say is common through the U. S. I have diligently sought it $-\&$ never found it. - L. gibba I have here \& in New Jersey, as well as trisulca \&o polyrrhiza. It is curious that with all possible pains I never succeeded in finding any species of Lemna in North Carolina.

Fedia radiata as described by you perfectly answers the specimens I find here. But what I called so in North Carolina is very different. It grows about two \& three feet high-The Corolla has not the slightest tinge of blue-the stamina are not much exserted \& the Leaves semiamplexicaule \& always deeply and lacerately dentate below; sometimes these indentures are even auriculately produced.

Iris versicolor. I felt sincerely obliged to you for the successful attempt to put an end to all my vexations concerning this Iris - \& I gladly assent to your reunion. But when you join the prismatica of Pursh \& gracilis Bigelow-as the true virginica of Linnaeus-which is certainly correct-I except from this union my prismatica of North Carolina, which I had long suspected not to be the same with Pursh's. That has a very long greatly flexuose stem, winding to the height of five feet, \& by no means flowers only in a terminal raceme but several lateral branches.

Are you unacquainted with the Iris cristata and Iris vernadiffering extremely in habit \& marks-\& both equally common in N. Carolina, the first on hill sides-\& the last (which approaches nearer to the lacustris you sent me than the former) in burnt woods not in tufts but always separate-\& extremely odoriferous.

Xyris brevifolia was found this year on the Bushkill by the students at Naz[areth] \& differs very materially from X. flexuosa Ell.I think you ought not to have united $X$. caroliniana with that. Sisyrinchium. I suspect you have not before you the same species which I have called by these names (to which I subjoin a third found near the Catawba covering whole meadows - answering bermudianum) because you seem to describe the leaves $\&$ scapes in both species as extremely similar.-In mine they are uncommonly different-the one answering your description-the other two not at all. Yours I have probably not 
distinguished from one another-but shall attend in future. If you please, let me send you specimens of my two broad leaved species from N. C.

Kyllingia monocephala grows here at Bethlehem. On the grasses

I can make no other observations-on account of my superficial knowledge- except mentioning which I should be glad to secure.

Scirpus pusillus Vahl-not known to me.

caespitosus $\beta$. callosus Big.--do.

subsquarrosus - do.

spadiceus-do.

Schoenus mariscoides. I have a grass from Georgia which I have arranged under this name which appears to be a congener of the Cladium Mariscus of Europe.

Rhynchospora fusca R. \& S.- has this grass been really found in Am.?

Dulichium canadense.-I have found a grass in appearance like $D$. canad. in the Lehigh Gap-Whether distinct enough to constitute a species I will not decide.

Cyperus dentatus - unknown to me.

Cyperus virens or one that I call so- $\&$ a very distinct species, is common here on the gravelly river shore.

Cyperus flavicomis.-I am pretty sure that I have found it here.

Spartina cynosuroides.-Can the tall ten foot high plant which

I have found in the rich plains on the Muskingum be the same with that of your salt marshes?

Paspalum stoloniferum.-I have specimens from European gardens \& certainly never saw anything of the kind in Am.

Milium effusum. I have found wild (it is not cultivated there at all) in North Carol.

A ristida purpurascens I should be glad to see in order to ascertain whether certain suspicious ones I find belong to this species.Your description does however not the least agree with specimens of racemosa derived from Muhlenberg.

Trichodium montanum. Let me see.

Agrostis stricta.-I am glad you could not find it more than myself.

- God knows what is meant.

A. compressa-quite unknown. 
A. juncea I think I have found.

A. longifolia as distinguished from clandestina I long to see. The latter I found at Harrisburg.

Arundo coarctata

brevipilis $\}$ would be very acceptable.

Crypsis virginica I long to see in order to disting. fr. Agrost (is) virginica.

Glyceria acutiflora do. do. from fluitans.

maritima-do.

pungens of Elliott I can furnish you. It grows here.

serotina.-I do not understand what you mean by this species, citing the $P$. palustris of Muhl.

Festuca fasciculata [fascicularis] — would be very acceptable.

Ceratochloa unioloides-ditto.

Diarrhena americana-I find by your descript. that I must have altogether mistaken this plant-and should be glad to get it. Trisetum purpurascens I should be glad to see.

Avena praecox.- Should the citation of Pursh not be Aira praecox? I desire it.

Aira flexuosa

$\left.\begin{array}{l}\text { aristulata } \\ \text { pumila }\end{array}\right\}$ are quite unknown to me.

Lolium.-I have found a remarkable Lolium-with sometimes furcate spikes-on the highest summit of the Allegany mountains - not yet examined.

Atheropogon apludoides - is not rare here at Beth.- - often three feet high.

Panicum pedunculatum - unknown to me.

macrocarpon-I desire it because I am doubtful about mine.

$\left.\begin{array}{l}\text { involutum } \\ \text { depauperatum }\end{array}\right\}$ both unknown to me.

At Bethlehem I have found a Rhynchospora, which you do not describe, which would be the only northern plant I know of not in your book.

The following is a list of my desiderata [lists 33 of the species named above, in reverse generic sequence] and beg to ask whether you want specimens of the following [lists 9]. 


\section{SCHWEINITZ TO TORREY}

My dear Sir

Bethlehem. Sept 25th I 823

I am afraid you will not only be astonished but vexed to be plagued every week with a letter from me-but I can't help it -I am so very desirous to let you see my Analytical Table of the Carices [67], concerning which I wrote you in my last, that I can't find it in my heart to lay it by \& send it to you inclosed, with the request to be so good as to make trial of it, \& to let me know what you think of the Idea. I consider it a most extraordinary improvement in the art of treating so extensive a Genus. To be sure it is necessary to refer to more detailed \& full descriptions in order to become fully acquainted with any particular speciesbut as for finding \& recognising, what the author of such a table calls any particular Carex, \&c. \&c.-I conceive nothing can be more certain. You will observe that there are about $25^{-26}$ species in this table which I have attempted to establish as new-Of these \& some others imperfectly described by Michaux \& Muhlenberg, \&c.-I think detailed descriptions would not take up much room.

As to giving the Table a place in your Journal-I leave it altogether to your discretion-\& beg you to keep it at all events as an Index to the manuscript copy of my now finished Monography which I intend to send you as soon as copied.

If the table should be printed-then your Journal. in future would be the proper place for the detailed descriptions of the thirty species about-which I think it would be necessary to give. To these I could perhaps on two octavo plates-add drawings of the principal parts of the described new Carices-It would not be practicable to give drawings of them in full-upon less than 12 or thirteen plates which is out of the question.

In case for any reason whatever the table is not admissible in your Journal, only let me know-but do not send it back for I am sure you will find it of use, when you get to the Carices \& do not forget my offer of sending you for inspection \& examination my whole Collection of Carices (which contains about I5o species) whenever you want it - so as to be not an unreasonable time out of my hands. I am with sincere sentiments of respect

Your most obd Servt \& friend 
P.S. The Carex subulata you formerly sent me is beyond all doubt the C. Collinsii Nuttall-this does not prove it not the subulata of Mx.-However, as I found one on the Allegany Mts.which answers $\mathrm{Mx}$. descript. equally well \& has not that curious formation of the rostr[um] mentioned by Nutt. and not by Mx.I have given the name subulata to this.

\section{TORREy to SCHWEINITZ}

My dear Sir

New York, October I5th I823.

I have neglected answering you so long that I should not wonder if you were altogether out of patience with me \& no longer consider me as one of your correspondents; but did you know my dear Sir how little time I have to sit down leisurely \& attend to my favourite pursuits, I am sure you would excuse me. It was my intention not to write to you until I sent the little package of plants I promised so long since, but I have delayed sending this until I could review all my Carices and add to the package such specimens in my collection as it appeared to me you had not seen \& also some doubtful ones: but lest you should think I was not in the land of the living I write now a short epistle. The little things shall certainly be sent in two or three days at farthest. Now to answer your letters of which there are three to which I have not replied. Ist, Sept. I6. I was indeed sorry that you could be of no assistance to me in determining that Rocky Mountain grass. Can it possibly be Aegopogon? I have written to $\mathrm{Mr}$. Nuttall to examine whether there is a plate of the plant in Humb. \& Bonp.'s large work [39] of which there is a copy in Boston. Roem. \& Schult. [48] do not quote any \& their account, copied from H. \& B. is not sufficient to settle the question-I can learn from Paris in the course of a few months, \& will wait that time rather than make a blunder. Your offer to send me Asters \& Solidagos I most eagerly accept-I expect to have much trouble with these abominable genera-Who will undertake monographies of them!2nd, Sept. 25th.-How delighted was I with your synopsis of the Carices! [67] It is indeed a very useful performance. I have examined it a good deal \& find it of much advantage in the determination of species, but you will not be offended at a remark 
or two which I shall make. The great objection to studying the Carices in the analytical way is the very variab.e character of many of the species. So that it is in many instances difficult to say to which of the two divisions of a series the specimen under examination belongs. To No. 4. 6. a considerable no. of species will often be referred when in fact they belong to different series, etc.-But I will in my next letter say more on this subject. I have at least 6 species to add to your Catalogue-viz. C. alba from mountains in Massachusetts. C. xanthophysa Wahl. (C. follic. $\beta$. xanth. Muhl. p. 244) (but can this be your striata?) $C$. lenticularis $\dot{M}$ ich. a species from N. England \& N. Y. very much resembling limosa. C. Bigelovii a new species from the White Hills of New Hampshire. C. - n. sp. from Cape May, given to me as a n. sp. by Collins!! Also a fine species from the Rocky Mountains \& another found by Nuttall on the Arkansas, besides some doubtful ones.-These I will send you, but having no duplicates of several of them, I must beg to have them returned.In your list at the end of the table $C$. saxatilis is omitted. It should be No. $521 / 2$. If I were in your place I would omit all the European species of which Pursh gives habitats except those which I had seen myself.-Such as C.arenaria, divulsa, leporina, remota $\varepsilon^{\circ}$ distans. Pursh evidently knew nothing of the Carices, any more than he did of the Grasses, \& has put down many species at random! Michaux's synonyms are also very obscure-Who knows his scirpoidea, ovata, miliaris, etc? You are aware, I presume, that C. Lagopus of Muhl. is the C. Fraseri of Ph. E Bot. Mag.? We have it here in a garden, but unfortunately I lost the opportunity of either seeing it in flower this season, or of obtaining a specimen for my herbm. I do not know how Pursh could have made such a mistake as to call C. Fraseri Mapania! See what Nuttall says.-We intend to publish your paper [67] in the 2 nd no. of our "Annals" as soon as it is revised. The manuscript you sent me I shall probably return to you with my remarksbut I beg you will do me the favour to let me keep it at length-

A few days since I received some charming Nepaul Crypts from Hooker \& in my bundle was a small package for you containing a copy of Greville's Cryptogamic Flora of Scotland [28]-I 2 nos. a beautiful work-I could not resist the temptation of taking a 
peep at it which I hope you will excuse-In the package was a letter from Hooker \& as I would have wished you to do in a similar case I send it on by mail as the bundle might not reach you in a week. Hooker writes me that he wishes to correspond with you-\& offers Nepaul \& other fine things.-This has prevented me from dividing such of my specimens as would bear the operation, knowing you would get much better from the Prof ${ }^{\mathrm{r}}$. himself. Really it would make your mouth water my dear Sir to see the odd \& charming things! Have you the Musc. exot. [Hooker, 35]? I told you, I believe, that the generous author had sent me a copy. This gentleman has made remarks on 240 crypts which I sent him last Winter.-Where his determinations differ from yours I shall take the liberty of mentioning them. It will only be in my power now, however, to mention some of his names of our Jungermanniae. J. sertularoides \& laciniosa are only J. ciliaris! I never could find the difference between the two former-J. tridenticulata Mich. is J. trilobata. J. capillaris is J. trichophylla Brit. Jung.--Several which I sent you but whose names are not yet returned, have been named by Hooker. No. 282 is J. bidentata 284-crenulata Hook. Jung. 28I ("J. nov." Schw.) is J. trilob. $\beta$ minor Hook. Jung.-Our J. bicuspidata (Flushing) is J.bident. var. min. No. 32 I which you called J.tridenticulata is $J .5$-dentat. Hook. Jung. (J. barbata Schmid.). No. 323 ("J. scalaris" Schw.) is $J$. sphagni with gemmae. We are doing a little in botany here, but want time badly-Halsey has made some additions to his Lichens. We shall have a good fellow to add to our number in 2 or 3 weeks in our friend Cooper, who is returning from his travels in Europe.-

\section{More anon-}

Believe me my dear Sir your devoted friend

\section{D. Schweinitz Esq ${ }^{\mathrm{r}}$.}

JOHN TORREYP.S. I think it best not to send your monograph [7I] until we agree about the synopsis [67] - then I should be very glad to examine the former by your specimens if possible. I know you will not be offended if I speak freely about it. We shall, probably, not always agree about species - I am for reducing the number a little.-I had almost forgotten to reply to your 3 rd unanswered letter which, indeed, was not the least acceptable for it contained 
your remarks on my Flora [89]. You may be assured my dear Sir I duly appreciate your kindly feelings towards me. I wish it were possible for you to see my manuscript as fast as I prepare it for the press (for I have only notes prepared-the copy for the printer is written out as fast as it is demanded) but this seems impossible, from the great distance between us. Of the species which you desire I can procure you a part-but not all, as there are several which I should be very glad to see myself, such as Aira pumila Ph., Ceratochloa unioloides \& Gratiola megalocarpa.Do by all means let me have the plants you offer,-particularly your Fest $[u c a]$ diandra. In my next I shall reply to some of your remarks-

SChweINitz To Torrey

J. T.

Bethlehem Nov. Ist I 823

My dear Sir

Yours of the I5th ult. gave me the most sincere pleasure, \& I beg to thank you in a particular manner for devoting a part of your so much occupied time to a correspondence which I am so sensible cannot be half as interesting to you as it is to me. No less obliged do I feel by your remarks concerning the Carices. Indeed I am anxious to add the species you mention to my analytical table [67] as well as to make some necessary corrections. To you who are so intimately acquainted with the Graminae it may appear an. inexcusable superficiality \& indeed I blush to own itbut still relying on the French adage "Qu'une erreur découvert vaut toujours une vérité trouvée" I must do so-I find that I stumbled grievously on the very threșhold (but I hope in that one instance only so badly). For upon a closer examination of my Carex leonina - I have made the discovery that it is no Carex at all but most manifestly your Scirpus planifolius. It is astonishing how easily one is sometimes misled by a prejudice that once takes possesion of the mind. Not having the smallest doubt of its being a Carex I neglected that part of the analysis which, when undertaken afterward at once convinced me of my mistake. But let me make a remark upon your objection to the analytical way I propose. I am perfectly sensible of its imperfections \& that it by no means suffices to give a full \& clear idẹa of a species. 
I only intend it as a means of facilitating the mutual understanding between different botanists of the identity of the plants they are examining, \& of making beginners generally acquainted with certain species-as such I am pretty sure it will prove itself of some importance. As a proof I mention that Collins who made very light of my table when I showed it to him, according to his private way of doing business, kept it by him, \& examined his dubious species by it-\& owned after he had shewn me some of these \& asked me how I would call them, that he had made out the same names exactly by my table. Perhaps another instance may be your suggestion, that my Carex striata is the xanthophysa of Muhl.-which I am very much inclined to believe (altho I see no male florets at the summit of the female spikes). If so that Carex is however ill described. I cannot entirely agree with you as to the great ambiguity of the subdivision-as soon as the precaution is used of having a good number of specimens before you. The slighter or greater variations in these appear to me almost always to indicate the true rubric with sufficient certainty. Besides by extending a principle $I$ have in a few cases adoptedthe remaining difficulty might be altogether obviated by contriving so as to lead the examiner right, which ever way he might happen to choose in cases of ambiguity. At all events I shall follow your advice, \& leave out all Pursh's unconfirmed Europ. species. I was not aware that the C. lagopus of Muhl. is the Fraseri \& am much obliged to you for the notice. I should very much like to get it. Solomon Conrad to whom I gave a copy of my Table for his own use-would insist upon striking off copies in order to be comunicated to Botanists-I have written to him not to do so-at least not till it has been corrected. If you actually think it worth while inserting (after correction \& augmentation) into your Annals I think it ought to be in that work, that the descriptions of my new Species should appear. You have not answered that part of one of my letters in which I propose sending you my great mass of descriptions for use when you are about that family in your Flora [89], not only, but likewise my whole collection of Carices for comparison-I should not mind its absence for two or three months. Such likewise would be my proposal about the Asters \& Solidagines. I feel altogether incom- 
petent to undertake anything like a monography of these-but should be glad to assist a better hand, by a view of my very numerous specimens.-Write to me explicitly whether you wish me to do so- \& I will put things into such a condition-that at a moment's warning when you want them-the whole mass may be sent to you.

You may easily judge how impatient I am to get Hooker's present-\& to enter into the correspondence he desires. Will you undertake to forward to him, what I wish to send holding me acacountable for all expenses? I believe I can in a short time make up a very good number of Fungi-which he seems to desire.

This promised work of Greville's [28] makes me long still more for the package from you-which week after week fails to arrive. I do not blame you-because I know by my own experience how little time is left to a man of business for these things-but I can't help telling you how much I desire to receive the little \& the large things you promise.

Believe me yours most sincerely

LEWIS D v SCHWEINITZ

P.S. Please to deliver the inclosed to Mr. Halsey whose direction I have inadvertently rendered illegible by a careless opening of the seal of his last.

\section{SChWEINitz TO TORREY}

Bethlehem 27 th Jan. I 824

\section{My dear Sir}

Knowing how much your time is occupied I by no means intend to complain that I have not heard from you (except by deeds of invaluable kindness-in the loan of your curious Carices) for so long a time. But I feel the necessity of improving the recovery of my health, which for weeks past has been such as to incapacitate me from any useful exertion, by indulging my mind with such occupations as are most likely to give it pleasure. And none can do so more than a correspondence with you. My last communications were in the same indirect mode with your last ones. In the box I sent to Mr. Halsey I not only returned you the Carices so kindly sent, but attempted to shew you my gratitude for the favor by adding a small number of plants which I conceived might be agreeable to you. I confess I long to hear 
your remarks upon them. In the same package (besides a small one for Prof. Dewey) I sent you with a request to accept it as a token of friendship a copy at full length of my remarks on the American Carices [7 I ] -When you have had time to look it over-I should certainly feel desirous to hear your observations upon it \& whether you conceive it in part proper to be communicated to the public. The latter part of last week I took the liberty to address to you a pretty large package for Dr. Hooker, Glasgow, containing Am. Fungi-but was then unable to accompany it with a letter. My request is, that if you know a way how to forward it, to be kind enough to do so-if not, to let me know \& to keep it by you, until I am able to point out how it is to be sent. I delivered that package into the Easton stage office $\&$ directed it to the Care of Mr. Halsey-because the stage driver is in the habit of delivering packets there. If you could find time to advise me of its arrival I 'should be very glad.

I do not doubt you are very busy in the prosecution of your great \& valuable undertaking. How far will the next number bring us? I am much obliged to you for the publication of my Table of Carices [67] - tho' I am sorry that it necessarily is broken off in two numbers-which however cannot be of any consequence when the volume is bound together.

Be so kind as to take this letter as it is meant only as a friendly attempt to remind you of me $\&$ to assure you that I shall ever be most sincerely

Yours

LEwIS D v SCHWEINITZ

\section{Torrey to SchweINitz}

\section{My Dear Sir}

New York, Feb ${ }^{y}$ I 5 th 1824

You would treat me no better than I deserve were you to erase me from the list of your friends, for indeed I have forfeited all claims to be considered as one of them. There is now before me a fearful pile of unanswered communications, \& I have begun to clear them away this day. I begin with you, to whom I am under the greatest obligations in every point of view. The whole business of apology I shall dispense with \& proceed at once to the subjects most interesting to us. 
Your letter of the $27^{\text {th }}$ ult. I received a few days since. It grieves me to learn that your health is not good, but I hope it will soon be restored that you may attend both to your duties \& to your favorite scientific pursuits. The Carices I sent you some time since, were received safely in Mr. Halsey's box, \& so also were the specimens kindly intended for me \& the invaluable History of $\mathrm{N}$. A. Carices etc. [7I]. The package for Prof. Hooker unfortunately came 2 days too late, a vessel having just sailed for Glasgow. I however mentioned in my letter to the Prof. that something from you was hourly expected for him, \& that if it arrived too late it should be sent by the next opportunity. Another vessel will probably be ready in two or three weeks; if not, I can send it by the way of England. Mr. Halsey has it in safe-keeping.

I have just looked at a proof of the continuation of your Carices [67]. It does not altogether please me, though I have in a few instances used the authority you gave me to make alterations which appeared necessary. I wish exceedingly that one or two names were changed, v. in particular muskingumensis \& granularioides. Is not the latter contrary to the Linnaean rules? Halsey \& myself had a great mind to take liberties here, \& I don't say we will not yet if the sheet is not printed off. In the $4^{\text {th }}$ No. of our Annals we propose to give some of the new or rare species from your Monography, for to give the whole would be inconsistent with the plan of our work. Mr. H. will make drawings of the new ones, unless you could have them done under your own inspection. If you could do so, \& will mention the species to be first described (i.e., the rare $\&$ new ones) they shall go to press as soon as the 3 rd No. is printed.

My Flora [89] is printing slowly, but pretty regularly. The 2nd No. is published, \& Ioo pages of the $3 \mathrm{rd}$. I am now in Octandria, Trigynia, but the printer has copy to the 3 rd or 4 th genus in Decandria. It appears to me that the whole work will be finished (if my life \& health are spared) by September or October next. This time will be necessary to make the necessary typographical corrections, the nature of the work precluding the possibility of rapid \& at the same time correct, printing. There will be probably IOOO or IIOO pages in all. The cryptogamia, exclusive of the ferns must be taken up in a separate volume: but by the time 
I arrive at this class I shall doubtless have the pleasure of quoting your N. A. Fungi, \& Halsey's Licholog. American.!! The Algae will give me some trouble \& they will be in the smallest number of any of the orders.-You may well suppose that I have but little time, after attending to my book \& some little practise of medicine, besides an occasional look (for I can't help it) at the curious things in mineralogy that are daily brought in. But having made some arrangements in my concerns, by which I have more leisure than formerly, I shall again endeavour to be punctual in my correspondence \& at least to write you a letter once in two or three weeks \& to exchange specimens of plants with you.

I think I mentioned in former letter that Mr. Cooper, one of our old botanical friends, had returned from his travels in Europe. He wishes to take up some little-known department of $\mathrm{N}$. American Botany, \& I advised him to let it be the Class Syngenesia. Do you think of any other field which he could cultivate more profitably? Should he engage in this or any other botanical subject, I hope you will find leisure to correspond with him.

I will now make some observations on the grasses etc. of your last package.

I. "Agrostis erect. 6 feet high" It appears to be A. sobolifera, though I never saw that species so tall.

2. "PoA. Beth." This, if not a var. of P. nervata, is new to me.

3. "Festuca diandra" is F. nutans of my book, \& of Muhl. herb" It differs some from Fest.

4. "Rhynchospora nigra." Not in my book. I am not yet satisfied whether it is new or not.

5. Cyperus virens. Think you this sufficiently distinct from C. parviflorus?

6. "Sisyrinchium anceps aut Bermud." This differs a little from my anceps but is very distinct from my mucronalum, of which I can probably send you a specimen. I have a very narrow-leaved kind collected by Delile in Georgia. What can it be?

7. "Cyperus vegetus." New to me, but you are probably right.

8. — punctatus Ell. very acceptable-as well as 9. Rhynch. cymosa from Beth.

Io. Dulichium canadense: Surely not distinct from D. spathaceum. 
I I. Cyp. "flavicomus." This is what I have supposed to be C. strigosus.

I2. Carex hystericina! This surprised me-I should certainly have called it [C.] Pseudocyperus. C.hystericina, as I have determined it, is a very different plant.

I3. C. costata. I can hardly distinguish it from $C$. virescens. Do you find its charats ${ }^{\text {ts }}$ constant?

I4. C. muskingumensis. Very near C. lagopodioides-

I5. C. cristata. I am glad that thing is settled. 'Tis common in N. Eng ${ }^{d}$. \& I never $\mathrm{k}$ [new what] to do with it.

I6. C. straminea. This specin ${ }^{\mathrm{n}}$. has but 2 spikes. Is that common? The other species I believe we have settled before.

The Carex we call xanthophysa is most certainly $C$. folliculata as fig ${ }^{d}$. by Rudge in Lin. Trans. [65] \& as Smith says of Herb. Lin. as he compared the specimen I sent him. So that $C$. follic. of Schk. \& Muhl. may be disc ${ }^{\mathrm{d}}$. The one you labelled $C$. striata I cannot make different. The one resembling it, with distant spikes which I supposed to be a var. of subulata, though much larger, was among Muhlenberg's specs. as a var. of folliculata! I am so perplexed with these things, that I am almost in despair of ever being able to distinguish the species with certainty.

If you have specimens of the following plants or can give me descriptions of them for my Flora, I should never forget the favour -Hydrangia vulgaris $\mathrm{Ph}$. Mitella reniformis. Silene nocturna. Sedum telephioides. Cerastium semidecandrum Muhl. hirsutum Muhl. villosum Muhl. Euphorbia repens. Euphorb. lutescens. Prunus pumila, nigra, pygmaea. Crataegus elliptica $\mathrm{Ph}$. Any plant which Pursh, Muhlenberg, etc. have not given as natives of the Northern States, would be highly acceptable, or indeed any new observations on old ones or habitats of uncommon species, etc. Do my dear Sir assist me to these, if you do not intend to use them in any publication of your own. Send me if you please, as soon as your health permits, a list of varieties in the classes between Decand. \& Polyand. (including the former).

I have just received from Monticello, Georgia, a package of Cryptogamous plants among which are some quite new to me. Those specimens which will bear dividing I shall certainly share with you. The latter part of this week I will put a package into 
the hands of the Easton Stage driver, \& I hope you will receive it safely in a day or two after.

I remain my dear Sir, most sincerely

Your much obliged friend

The Rev ${ }^{\mathrm{D}}$.

JOHN TORREY-

L. D. Schweinitz

Bethlehem

Pennsylvania

TORRey to SchWeinitz

New York, Feby 27 th, I 824 .

My Dear Sir

A few days since I wrote you a letter in which I promised to dispatch in a short time a package of plants for you. As usual, I have been several days after the time, but the little I have been able to get together is sent according to your direction, by the Easton stage. They are, indeed, trifles \& I had a great mind not to send them-but you must take the will for the deed. The cryptogamia are numbered according to corresponding specimens which I have retained, as usual. I have, however, mislaid the memorandum of my last mission, \& therefore I have begun with the number 6oo. Do, My Dear Sir, oblige me so much as to give me your opinion respecting these specimens, \& also of those sent in a former package, some time since, of which there are some yet to hear from. There are a few specimens of cryptogamia, etc., from the West Indies, being duplicates of some lately presented me by $D r . R$. Madiana-I wish you would oblige me with your determinations of these. More from the same quarter I shall have for you soon.

To make my little package more acceptable, I have added to it the 2nd. No. of my Flora [89] which goes partly through Pentandria Digynia. A third number is nearly finished, as you will see by the last proof-sheet but one, which I transmit as evidence. There will probably be about 7 Nos. in all, or about I Ioo pages. I beg you will give me your candid remarks on this last No. which contains three or four typographical errors, independent of others, more important. But by all means let me profit by your observa- 
tions \& advice respecting that part of the work which yet remains to be printed. Descriptions or localities of new, rare or doubtful species will be most precious to me; and I may add, will make my book more valuable to others.

I will here make some observations on a number of plants which will soon come in order for publication. Please answer my queries as far as you are able.

I. Arenaria canadensis Pers. Is this more than a variety of $A$. rubra altered by its maritime situation? At any rate can it be distinct from $A$. maritima of Smith?

2. How shall I distinguish the caulescent species of Oxalis? Surely Elliott has made too many species. The characters of $O$. stricta \& corniculata given in the books apply nearly as well to one as the other.

3. Is the Cerastium glutinosum of Nuttall the C. longepedunculatum (!!) of Muhlenberg?

4. Is C.tenuifolium of Pursh distinct from C. arvense of Europe?

5. Can Lythrum verticillatum be a congener with $L$. hyssopifolium \& some Europ. specs.?

6. What is the Euphorbia portulaccoides of Muhlenberg's Catalogue [52]?

7. Is Talinum teretifolium as Mr. Rafinesque asserts, a peculiar genus?

8. What species of Prunus have you found in Pennsylvania? There are several mentioned by Pursh which I never saw. Indeed, I think he has made considerable confusion among many of the species. His $P$. depressa can scarcely be the straggling prostrate bush so common on Long Island \& known by the name of sand cherries.

9. Crataegus also puzzles me. I want your list of northern species, with your synonyms. C. elliptica \& viridis I am curious to see.

I0. Sorbus microcarpa. Can you let me have a specimen of this? I I. Pyrus ovalis. Is this a good species?

Thus far I will go at this time, \& as soon as I hear from you will furnish another list of such plants as I wish your opinion respecting.

It is well your package for Dr. Hooker did not come a few days sooner for the vessel by which I sent some things was wrecked be- 
fore she reached Sandy Hook and I fear almost every thing lost. Should the gentleman who took charge of my packages \& who was going directly to Dr. Hooker with them, take passage in another vessel, he will still be the best person to intrust with them. I have just received a letter from the Dr., in which he expresses the greatest desire to obtain specimens of North American plants. He is engaged in writing an Universal Flora, $\left[{ }^{*}\right]$ in English; the first part of which will appear in April next. This work will be arranged according to the natural orders.

Our Lyceum flourishes more than ever, but still we labour under great disadvantages for want of funds. If we had such a man as Maclure to patronise us, the Academy of Philadelphia would not be before us many years. I send you a subscription paper for our Annals to circulate among such of your friends as you think would subscribe. We need some more subscribers to defray our expenses.

I mentioned some time since that Prof. Hooker had presented me with a copy of his Musci Exotici [35], a splendid work with numerous plates-Should you wish to loan this for a month or two, it is entirely at your service. I had commenced selecting some duplicates from the Nepal specimens sent me by the author, but I desisted, knowing he certainly would himself send good specimens of which I could only spare fragments-Still If you wish them, they shall most cheerfully be sent.

I send you a specimen of a Fern I once mentioned. It resembles Woodsia in some respects, but wants the capillary margin to the involucrum, \& the capsules are not pedicellate. By the way, I have often examined specimens of $W$. hyperborea from Europe \& never could observe the capsules \& involucrum as represented by Brown in the Linnaean Transactions [14]. Our plant must be new, though it may have been included in Aspidium obtusum by Pursh \& others. I also send you a Woodsia as it is called, which is probably $W$. ilvensis, though in this neither can I find the involucrum, nor the pedicels of the capsules.

* [Hooker, Joseph Dalton. A sketch of the life and labours of Sir William Jackson Hooker. Ann. Bot. 16: XCIII (footnote). I902.

"My father did contemplate such a work, but I am very sure that he never put pen or pencil to paper in prosecution of it."] 
The copy of my Flora [89] I send you was damaged last night by the rain which penetrated my room. I have not another at hand, but you shall have a good one before long.

Yours truly

JOHN TORREY.

SChWEINitz To Torrey

Bethlehem March 3d I 824

\section{My dearest Sir}

It is not surely to me that an apology is due for the interruption of our to me delightful correspondence for no less than two of your favors (of the $15^{\text {th }} \& 27_{\text {th }}$ ult) are before me unanswered. They gave me the most lively pleasure I assure you-but so much the more I am grieved in being able to give you for the present so little satisfaction. Unexpected hindrances have ever since I completed my little Carex labors [7I], such as I have taken the liberty to trouble you with-almost entirely prevented me from paying any attention to my botanical studies \& still do so in a great measure. The first \& worst was my indisposition, which but for an extraordinary exertion, threatened to immerse me in the most dreadful of all states, complete Hypochondria.-You can judge of what I was approaching when I inform you-that a resort to Botany, which had ever been a sure cure \& relaxation to my mindnot only failed of its wonted efficacy-but that I even at times was upon the point of sacrificing it to the Demon that was assailing me, \& felt something of that mental derangement which I presume is the precursor of suicide under other circumstances, prompting me to destroy my collections-or at least to dispose of them out of my sight. I thank God, that by the help of some good Doses I was enabled to conquer $\&$ am quite restored to my senses as well as to my health. But I had not yet fully recovered when a press of the most urgent business came upon me, which altho' it put me in a useful activity has utterly prevented me from taking up (except for a moment at a time) anything not in the absolute path of duty - nor am I yet entirely thro'-altho' I begin to perceive soundings.

Under such circumstances you will forgive if I am not yet able to satisfy all your requests. The package you announce in your last has not yet arrived-I shall however take measures immedi- 
ately to find out whether it is at Easton.or not. Permit me just to go thro' your two favors \& to remark, what I am at present able to remark. Do by all means, make exactly such alterations in names \& barbarities of any kind which I have committed as you think proper. I have a most shameful habit of putting down names for what I consider new, without sufficient reflection \& afterwards forget to alter them. I am sure I wish you may have put something less indianic for my Muskingumensis-for if that should pass - who knows some future Botanist might think himself justified in calling a new Carex found by good luck near Chambersburg, Penns. (\& I myself found one there that may possibly prove new) Conecocheaguensis to the utter dismay of all Europeans except the Russians, who might possibly punish us by even calling one Tschernitiskowensis!! Into "granularioides" meaning "like granularis" I suffered myself to be led by Prof. Dewey-it is certainly wrong. With the greatest pleasure I would furnish drawings of some of the species, you will kindly insert in the $3 \mathrm{~d}$ [no. of the] Annals, if I could flatter myself with anything like leisure-as it is Mr. Halsey will do me the greatest favor to attend to them. I rely implicitly on his accuracy \& skill. I am delighted with the prospect of soon getting your published 2 Number of the Flora [89]-I hope however you consider me as a subscriber-as well as to the Annals - of which I very much long to see the number cont[ainin]g the rest of my table [67].. The correspondence of Mr. Cooper will be highly acceptable to me-\& nothing more important could he do than to attack Syngenesia -if he does resolve, the loan \& use of my collection shall be at his service.

I am greatly obliged to you for your remarks on the few grasses I sent. Is the Poa-n. 2. I sent-the one with black scales? - that surely is no var. of nervata. I have since been convinced that my $F$.diandra is the nutans. 5 Cyp [erus] virens?-I never saw the parviflorus, \& cannot therefore know whether it be that.-You are certainly correct in believing my Dulich [ium] canadense the same with $D$. spathaceum. It is a variety however somewhat constant.

The history I have given of $C$. hystericina's name is correct -but it is very probable that it is nothing but C. Pseudocyper[us] - of Am.-not however the Pseudocyp. of Germany.-I3. I 
confess I begin to doubt a little about my Carex costata altho it is very constant-if a mere variety. I hardly think you would conceive the Muskingumensis so very near lagopod. if you had seen it grow. I6. The greater part of my straminea had 3 spikes.

Among the plants you desire specially I am sorry to say that Hydrangea vulgaris (common here) is the only one which I can furnish. Of Sedum telephioides - common on the mount. of Carol.I have but one specimen-it is very near [S.]. Teleph [ium]. Cerastium hirsutum Muhl. I think is certainly only $C$. vulgat. If possible I will [add] to this letter a list of our rarer plants here-so that you can point out such as you would choose. It would be extremely acceptable to me to get some of the interesting Georgia Cryptogamists you allude to.

As regards the queries in your last I am conscious of not being able to give you much satisfaction-as they chiefly regard matters that I have only superficially attended to-

The Arenaria canadensis-I have only seen in one specimen from you. The caulescent Oxalis-puzzle me as much as youbesides the stricta \& corniculata-the one with large broad, the other with small leaves \& certainly very similar-I however have found one other frequently in Carol[ina] (not here) which I think very different (among the rest the folia are invariably tinged velvet purple) but I have not been able to reduce it to any of Elliott's.-The Cerast. longepedunculat. of Muhl.-by specimens from himself is most undoubtedly the glutinosum of Nuttall-concerning the tenuifol. of Pursh I have little doubt that it is the same with European-\& American arvense the latter perfectly the same with arvense E.-covers certain rocks on Delaware near Easton. I have doubts myself whether the Lythr[um] verticillat.-\& $L$. hyssopifol $[i u m]$ are congeners (confessing however that I have rarely studied the generic differences of my plant)-but I think it certainly is of the Lythrum Salicaria of Europe. Among my Plants of the Pine barrens N. C. I have one I call Euph. portulacoid.but I am not competent to say it is the Muhlenbergian-mine is a distinct plant.

The Talinum teretifol[ium]-very common on rocks in Carol. - is so distinct a plant that I never once recurred to the generic examination.-As to the genus Prunus \& [the genus] Cra- 
taegus - I have hitherto contented myself with collecting as many forms as I could get-but have never attempted a comparison of synonyms-I find few Crataegi here-at Salem they were very numerous. These two genera I was in great hopes of bringing into order by your means. Sorbus microcarpa I am quite unacquainted with-\& tho' I think they are two species-the northern \& southern Pyrus Botryap[ium]-I do not know which is that \& which ovalis -I rather however think our northern one is "Botryap[ium]."

I shall exert myself to procure subscribers to the Annals \& should have done so before this, if I had been acquainted with the terms.

Have you ever seen that most remarkable Neottia which Solomon Conrad found last year-the flower very much like tortilis. - but with four leaves at base thus [figure inserted].

I wish Mr.Halsey would let me hear from him again-I find I must refer you to the margin of the manuscript I sent him for Bethl. plants. I have no means left to make out a list, until I get that back-But even that is deficient \& does not contain the Bethl. plants further than Syngen[esia].

Hoping I shall soon receive your promised Packet

I remain Yours affectionately

Lewis D v Schweinitz

\section{SChWEINITZ to Torrey}

My dear Sir

BETHL. March. 28th I 824

Since I had the great pleasure to receive your last favor of Febr. 27th which I answered immediately I have at length likewise received the valuable package you sent me-the contents of which were most acceptable indeed. I had begun to make some observations on the $2 \mathrm{~d}$ number of your excellent workwhich however have been quite curtailed by a press of duties.You will forgive me for sending them $\left[{ }^{*}\right]$ to you in their present crude state-conceiving some of them may however occasion you to point out what you would like to know more particularly. I have been delighted by your reported progress \& begin to look forward

* [Printed following this letter.] 
eagerly for the next number. A few days ago I received the $3 \mathrm{~d}$ $\mathrm{N}$ - of the Annals-\& am sorry to see that you have not corrected all my barbarities. If we had had time to discuss the matter I should have preferred not to have the Carex table [67] printed in the tabular form, which renders it necessary to put it in lengthways \& renders its use somewhat inconvenient. But in the main it will do well enough.

As regards the rest of the contents of the package I was much delighted \& instructed by them-especially the American plants \& those from Guadeloupe. I hope soon to be able to inform you of what I think the undetermined specimens are. As to the mosses from Georgia I think with few exceptions they are not distinct ones. My time is so much occupied just now, that I have not had leisure to submit them to any critical examination. I wish you had put up for me some of the Nepaul specimens from Dr. HookerGod knows when I shall ever receive anything from him-But do not deprive yourself. The fern you sent me-as a Woodsia is undoubtedly the Aspid. obtusum of others-my specimens from Muhl. agree exactly-but I believe it is a Woodsia. Mr: Conrad of Philad. gave me specimens under the same conviction.

It was unlucky that the moisture from the wet cover of the number of your Flora [86] (which is only damaged in the blue cover \& conseq. of no account) occasioned on the long journey of the package, that all the mosses \& some of the West Indian plants. were covered by mucor in such a manner as seriously to injure some of them.

What can the matter be with our friend Mr. Halsey? Since I sent him my Lichens I have had no letter from him, \& fear he is unwell.

I was much pleased with Mr. LeConte's paper on the Utriculariae [43].- It is a matter of the utmost consequence to elucidate single genera in that way \& nothing I think could tend more to render the Annals as well as the Phil. Journal [6o]- important \& useful, altho its size admits only of such reviews of the smaller Genera.

Accept dear Sir - the assurance of sincere respect \& friend[ship]

from Yours affectionately

Lewis D V SCHWEINitz 
Heuchera pubescens. I think the species you describe is past all doubt the $H$. caulescens of Pursh-a most elegant plant with very large flowers \& leaves on the stalk. I hope to be able to send you a specimen. It is very common in the Allegany $\mathrm{mts}$.- I found it likewise but much smaller at Harrisb[urg].

I. Plants in Dr. Torrey's Flora highly desirable [lists $3 \mathrm{I}$; I3 from no. I, I 8 from no. 2].

II. $\Gamma$ emarks on No. 2 of Dr. Torrey's Flora.

I. Digitaria serotina. This species is marked + . Why? It grows not rarely here at Bethlehem and is very distinct from any of the others.

2. Andropogon virginicum. Are you confident that this is the same with the $A$. dissitiflorum Elliott?-I have two species, one of which I call $A$. virg.-the other dissitif. both from Carolina.

3. Androp. nutans. The species which grows here plentifullyand which agrees well with avenaceum, is I think considerably different from the one I called nutans at Salem-perhaps a variety only. The Bethl[ehem] species differs at first sight, by the dark brown color of the seeds-which in Carol. is always quite light.

4. Proserpinaca pectinacea. There is not the slightest doubt in in my mind that this species is perfectly distinct from the former [P. palustris].

5. Galium tinctorium. I believe with you that what we call tinctorium here is not distinct from trifidum. But the true tinctorium of the Musking[um] from which the Indiansaccording to all our missionaries-make their red dye-is different.

6. G. boreale; not rare at Hope, New Jersey, and Easton. What I have by the name of bermud[ianum] appears to belong to this.

7. Sanguisorba media. I have found a species, exactly answering this, which appears distinct enough-much smaller than canadens $[i s]$ in all its parts.

8. Plantago media.-My specimen from this vicinity is exactly like the $P$. media and quite distinct from major.

9. Have you seen the Exacum?--Pursh or Nuttall doubts its existence. 
IO. Potamogeton fluitans of Europe is extremely different from natans - but I have never met with it in Am.

II. Potamogeton pauciflorum; this is common here-but it is surely not the $P$. gramineum of Germany, which again is a most common brook species in Carolina, agreeing perfectly with the German one.

Lithosperm $[u m]$ latifolium of $\mathrm{Mx}$. is a plant perfectly distinct from L. officinale-and common in the western woods-Bartram's I presume is not the true one.

Lysimachia hybrida as I have it in Salem-is surely distinct from L. ciliata.-Why do you consider that and heterophylla (of which I am ignorant) the same? The name seems to require quite a different plant.

Verbascum Blattaria. I am very sorry that I possess but one specimen-found by myself in Surrey County, N. C.- of $V$. Claytoni. It is as distinct and beautiful a species as can be imagined.

Ipomaea purpurea and Nil; tho these are probably not indigenous here-there can be no doubt of their being so southwardly.

Convolvulus spithameus and tomentosus [the name Convolvulus tomentosus does not appear in Torrey's work, but Calystegia tomentosa is given as a synonym of Convolvulus spithameus].

I fancy there must be a great confusion as regards this and the next. Spithameus, common in Carol., I have not observed here, and there it is never trailing nor pubescent-and C. tomentosa is absolutely tomentosely velvety and trailing (I therefore doubt whether it is stans). - - It was found by me on the tops of the Allegany mount[ains] in quantities.

Impatiens. I am astonished to read your remark concerning the similarity of pallida and fulva-for what I distinguish as each-are altogether different.-Both grow here.-The flower of pallida is double the size of fulva.

Ceanothus. The common species in Carolina is utterly devoid of pubescence except on the ribs-but it is not altogether herbaceous - the stems do not die more than half down.

Campanula americana and acuminata - as distinguished by methe former only in Carolina-the latter here and Ohio-are certainly two very good species-The leaves of the latter are very thick, those of the first remarkably thin. 
Viola clandestina. I have found past flowering in great quantities about the coal mine, Lehigh-but I confess that since I have studied the $V$. blanda in nature here at Bethl[ehem] I begin to believe that they are not distinct, especially since I have had an opportunity to recur to my deceased friend Steinhauer's drawing and find I am mistaken as to his having represented the chocolate-colored petals. I think it is a very happy thought of yours to refer the expression of Pursh to the fruit. $V$. eriocarpa Swz. Since I am in the habit of finding $V$. pubescens with and without woolly capsules here (it was not met with at Salem), I am more determined in my opinion that my eriocarpa is a different species.

Asclepias nivea-found by me in the Alleghany mts.-is the only species which I have from the northern states not in your Flora, in the present number.

\section{TORREY TO SCHWEINITZ}

My dear Sir,

New York, May 20th I 824.

Surely I am the most unfortunate man in the world when I have for years anxiously desired to behold your face \& yet was a few weeks since within a few yards of you or perhaps even passed you without my knowledge. On this day last month I became a benedict \& on the 27 th I was in Philadelphia with my wife, where we remained four days. It was with the deepest regret \& mortification that I learned from Mr. Collins, the evening before our departure, that you had been in Philadelphia nearly all the time that we were there, \& that you had only left town but a few hours before. What a disappointment! I don't know a person I am more anxious to see than yourself \& to find I have lost an opportunity of gratifying myself which may be the last for a long time yet, made me quite melancholy. You will now be prepared, I trust, to make abundant allowances for the manner in which I have treated you for some time past; for some preparation, you know, is necessary, before one can make so great a change in his situation. There are now before me two of your letters, the latest of which I received at least six weeks ago. I am now clearing off a mass of business which has accumulated on me during the 
honey-moon \& some time previous. You are one of the first of my correspondents whom I attend to, for to none am I under more, if so many, obligations as yourself. I am delighted to hear that you did not become a victim to the "Demon" which assailed you the last winter. May you continue to enjoy uninterrupted good health, \& have inclination \& leisure to prosecute those studies which are so dear to us both!

I told you that the synoptical table of Carices [67] was partly worked off when I received some of your \& Dewey's alterations \& that they arrived too late. The paper looks very well however. In our next no. (the 5 th) we propose to commence the detailed descriptions of new \& rare species from your monography [7I]. It is uncertain whether we shall give a plate of them in that number but we shall do so in the 6 no. if possible. Should you have any corrections to make they will be quite in season if sent in the course of two or three weeks. We will send you, shortly, a list of those of which we wish drawings made. Several species may be drawn on one plate after the manner of Schkuhr.

You ask me if I have seen a species of Neottia, resembling $N$. tortilis but with radical leaves. The common tortilis, as it occurs here, very often has one or more ovate radical leaves, which are frequently reticulated, as in $N$. pubescens, though smooth, and much smaller. I have received specimens of it in this state from many parts of the northern States, \& from the western parts of New York. It does not appear to be a new species. The $N$. cernua I know to be a very variable species: sometimes occurring only $2-3$ inches high, with lanceolate leaves, $\&$ at other times acquiring a height of nearly 3 feet with very numerous flowers.

I regret to learn that my last package was in such a damaged state when it reached you. The copy of my Flora [89] shall be replaced by another one. For your criticisms on the 2 nd no. I render you my warmest thanks; hoping, however, that you will, when more at leisure, extend your remarks \& expose all the errors you can detect. The Digitaria serotina of your neighbourhood, I should be much pleased to see. Do let me have specimens of it. Also of your Sanguisorba media! It really pleases me to find that you agree to my opinion respecting the Viola clandestina. It surely must be blanda. 
I mentioned to my friend Halsey some time since that you were desirous of hearing from him \& I presume he has by this time written to you. The Salem Catalogue etc. are quite safe \& will be returned shortly. $\mathrm{Mr}$. $\mathrm{H}$. has but little time to devote to science, but he is very industrious \& a good economist of what leisure he has.

We are quite active in our Lyceum, having now some good working members. Cooper, DeKay \& Van Rensselaer set out the other day on an expedition to New Jersey for plants \& organic remains. We expect much from their science and zeal.

My Flora [89] is at a stand for a little while. The Ist vol. which closed with Icosandria is finished, \& the part that is due to you shall be sent soon. Please get ready your rarities etc. for the 2nd vol. [*]

I hope soon to have ready a small package for you,-principally of foreign Cryptogamia. There will be among them some of the Nepal musci etc.

The inclosed letter I received in a package from Professor Hooker. The seal was broken by me, through mistake. I discovered my error after reading one or two lines \& immediately desisted. Pray don't for the world think I did it intentionally.

Since I wrote you last I have received many interesting plants, but no new books. There is something doing in Europe in Botany. Hooker you know is engaged in writing an Universal Flora in English.[†] De Candolle in a Synopsis plantarum [16], etc. In the first vol. of the Lin. Trans. of Paris is a long paper on mosses by Beauvois [57], with some excellent plates. It is very much like his Prodrom[e] [58], which he published in $1805 .-$

\section{I remain, Dear Sir}

Yours most cordially JOHN TORREY.

P.S.-June Ist. This letter I have just found where it was accidentally laid some days ago. It was my impression that I sent it to the postoffice. Do pardon my neglect.

* [Never published.]

$\dagger$ [See footnote, p. 205.] 


\section{Schweinitz to Torrey}

My dear Sir

BETHL. July 6th I 824

It will occasionally happen that even a correspondence so agreeable \& interesting in its nature as the one I am happy enough to enjoy with you, becomes subject to interruptions. The only remedy is to resume as soon as possible. Yours of the 2oth May reached me some time in the middle of June \& gave me the utmost pleasure-as a resumption of the kind on your part which I instantly felt the imperious duty of reciprocating, more especially as I have none of those excuses to make, which you urge upon me with irresistible force, for when a Lady's in the case-of course all other things give place-but alas! see how I have again neglected, what in itself gives me such pleasure. Nevertheless I hope it is not too late to express my sincere congratulations upon your conversion from celibacy, in which besides my very unfeigned share in your happiness, I am not without interested motives. For I hold it a matter of course that every Lady, above all a married one, must necessarily become a promoter of the worship of Flora preferably to that of the author of Dust and Dirt, that enemy of all neatness and cleanliness in the house whom mineralogists delight to honor. My disappointment \& vexation was at least equal to yours, when I found by your kind letter how near you were to me at Philadelphia, but it is surpassed by my anger at Mr. Collins who might have told me, as I had a long conversation with him about my desire of seeing you, which had almost prompted me to return home by way of New York at that time. I am now glad I did not, for that would have been worse still had I missed you there. I am not without hopes, provided the yellow fever keeps out of the way to be able to effect a visit some time in the fall. Your kind interest in my health gave me sincere satisfaction. I thank God I have nothing to complain of \& would have been active this year to a much greater degree than has been the case in Botany if my official duties had not been unusually pressing. I however contrived a short journey thro' the mountains between this and the Susquehannah in May, which has not been quite unproductive.

I should have been glad to receive the list of Carices you want me to give drawings of before this-for it will now be too 
late, as within a fortnight I shall have for a week or two to make an absolute pause in my botanical pursuits on account of businessI have very carefully revised the Carices this season-but have no other correction to make of consequence, except requesting you by all means to strike out the whole of the description of my supposed new Species Carex typhinoides-for I have found it in great plenty this year growing in such a manner as to leave no doubt that it is only a variety of $C$. squarrosa. All the rest of my species I have found confirmed, \& met with a number of new ones, besides finding a number here $\&$ in the mountains, which I had before only met with in North Carolina. I am obliged to you for your answer concerning the Neottia, \& shall attend to collecting for you Digit [aria] serotina. I have now observed the $V[$ iola $]$ clandestina in plenty in the Beech woods (by the bye I only past thro' a small corner of them, \& conceive they must be very fertile in interesting plants more especially Musci \&c.) \& am quite certain it is only a variety of blanda.

You must have mistaken my remark concerning your 2d Vol of the Flora [86] - that is not at all damaged-but I am extremely desirous of seeing the $3 \mathrm{~d}$ number. If you could immediatley on receiving this hand it to my friend Rev. Benj. Mortimer, Fulton Street (\& doubly should I rejoice if you could add the small package of Cryptog. of which you speak-trebly if there were some American phaenogamous additions from the North, South, East, or West) I should probably receive it soon as he is comming here in the course of the week ending the $25^{\text {th }}$. When he returns I hope to forward to you a considerable packet cont'g near ıoo Phaenog. \& Cryp. for Prof. Hooker-for alas I believe I have nothing more to send to yourself. Be assured that I shall always desire you to read any communication Prof. Hooker may make to me- so there is no need of excusing your opening his letter.

I wish I could say as you do-that since my last I have received a good number of new Plants-I did expect many-but I have got a very few only- \& begin to think my Den the very contrary of the Lion's, for there are a great many more footsteps going out than in. This, however, I beg you not to apply to yourselffor there is a good path trod by your "In trades." The matter is that it is not altogether easy to get more after one has got a certain quantity. 
No news of Mr. Nuttall's return yet! It is rather a dangerous experiment to get a large fortune as I hear he has-it is even more so than Mineralogy.

You will greatly oblige me my dear Sir to let me hear from you if possible by Mr. Mortimer. Be so good as to present my best respects to Mr. Halsey in whose debt I am I believe.

I remain yours most cordially .

\section{LEWIS D v SChWEINITZ}

P.S. My dear sir, now that you have so very properly followed Benedict's example, I beg leave to inform you, that it is almost an indispensable piece of fashion to make the tour of Easton, Bethlehem (\& Mauch Chunk if you please) for a newly married gentleman \& his lady \& will not doubt your willingness to follow the good fashion at least as far as Bethlehem, where I hope to give you cogent reasons for stay. That unfortunate namesake of yours, of whom I have heretofore told you, keeps pestering me with disappointments - as yesterday calling upon me-in order to convince me of the probability that some species of grasses-white clover for instance \& sorrel-according to his classification of grasses-occasionally spring up without seed or root from mere chemical composition of their component parts, of which it appears he considers marle a principal one.

\section{Schweinitz to Torrey}

Bethlehem Sept. I 3 th I 824

\section{Dear Sir}

I have succeeded in persuading myself that the circumstance of my not receiving an answer to my long lost letter of a forgotten date was owing to some absence of yours from home. I sincerely hope that my not receiving advice from you of the safe arrival of a very large Packet for Dr. Hooker at Glasgow which I forwarded to you by my friend Rev. Benj. Mortimer of New York is owing to the same circumstance as I should be very sorry indeed to learn that anything untoward should have happened to that package.

The object of my present letter, under the hypothesis that you may now probably have returned from the supposed Journey is to beg leave to introduce to your acquaintance my highly re- 
spected Friend, Bishop Hüffel of our Church whom you will find among other estimable qualities imbued with the most lively interest \& profound knowledge of almost every part of the Natural Sciences, especially Mineralogy \& Botany. I am sure it will give you pleasure to see him \& he very warmly desires to become acquainted with you.

As I really burn with impatience to see your third number of the Flora [89] - I beg earnestly you may be so good as to send it hither by Bishop Hüffel, who will return towards the end of the month-\& if you can add anything in my line from your collections you will highly oblige.me. As I have not a moment to spare (4 weeks sickness has greatly augmented my business \& deprived me of the time I desired to devote to Botany) I only add that I am as ever

\section{Yours most s ncerely}

LEWIS D v Schweinitz

\section{TORREy TO SCHWEINITZ}

My dear Sir,

West Point November I I th I 824

Two esteemed letters of yours have long been reproaching me with neglecting one of my best friends. The first I received so long ago as the 6th July last, \& the 2nd the I3th September! Yet I can hardly say they could well have been answered before. You have heard, doubtless, of my being appointed Profr. of Chemistry $\&$ Mineralogy in this place. I have been here nearly 3 months \& my labours during that time have been incessant. I had been for a long time a candidate for the situation here-but after Dr. Percival (my predecessor) was appointed, I gave up all hopes of obtaining it. At length, however, this gentleman resigned, \& I was chosen in his p'ace. As this was unexpected to me $\&$ as I was somewhat rusty in Chemistry- $\&$ had not a line written for lectures either on this subject or on mineralogy, you may suppose I have had few leisure moments until this time. For until lately I had to deliver 2 distinct courses of lectures, $\&$ to write a lecture a day. At last, I have more time; my assistant having returned to duty. My situation here is very pleasant,-almost the only thing I regret about it is that I have so little leisure to devote to 
botany.-There is, however, a vacation of 2 months in the year (July \& August) which I can spend as I please.-During our reviews also two more months are spent without my lecturingwh[ich] relieves me from that wh. consumes the most of my t meviz. the writing of lectures.-Besides-after this year, if God spare my life, I shall have a complete course entirely written out. You see I am still devoted to our favorite science-I hope never to give it up-

Really it is time you received something more from me than promises-for these have been reiterated by me for the twentieth time \& nothing has been sent to you yet.-Having at last settled myself \& having a beloved partner who takes a strong interest in my favorite pursuits, I hope with her help to arrange $\&$ place in complete order my little collections \& thus to know certainly what I possess. - Then it will be in my power to be more useful to my friends-\& also to furnish them with my precise des:derata. You must not be out of patience with me for I do as well as I can. You are yourself to blame, for by your liberality bringing me so much in your debt.

In your 2nd letter you hope that the cause of my long silence was my absence from the city.-As you now know how I have been occupied for some time past I trust you have already pardoned my neglect. But there is another fault I have been guilty of wh[ich] I fear will not so readily be overlooked by you. One of the two bundles of plants which you sent me for Profr. Hooker (that brought by Mr. Mortimer) was only forwarded about a month since! My apology must be frequent absence from the city and almost continual hurry \& business. It has, I hopeere this reached him in safety. The other package I delivered into Mr. Halsey's hands to transmit-as he was in the mercantile way \& could watch the opportunities for Glasgow. Did you receive a letter from the Prof ${ }^{r}$. a few days since? He also sent me a package for you-after looking at the contents (wh[ich] I knew to be Greville's Cryptog.) [28] I sent it [in*] care of Mr. Mortimer in N. Y. with a request that [it should] be sent you by the first opportunity. [I have] litt e news to tell you-Hooker has

* [Note: The paper is torn at this point and several words are omitted in this and the following line. 
just sent me the Ist vol. of DeCandolle's Prodromus [I6] - a wonderful work! Greville his Flora Edinensis [27] etc.

Halsey is working hard at the Lichens, Cooper at fruits, \& the rest of the members of our Lyceum at their several favourite departments. Elliott's 6 th No. [22] is received but he says a 7 th no. will be necessary to complete the 2 nd Vol. I shall immediately dispatch my 3 rd No. [89] to Mr. Mortimer for you. I.long to finish the work.-Do you still intend to join Halsey \& myself in writing a cryptogamic Flora of N. America? Perhaps I may not have time for this year to do much-but I am steady to my purpose-

How I regret missing Bishop Hüffel! Indeed it was a great loss to me.

I remain your sincere friend

JOHN TORREY

\section{SChWEInitz to Torrey}

Bethlehem Dec 5 th 1824

\section{My dear Sir}

Really your favor of [the] I I th ult. came in good time to save me from sincere concern on account of the loss I began to apprehend that I \& your friends had suffered by your absolutely vanishing out of all record. It has given me proportionate joy to find, that you have only vanished to rise in glory at West Point \& I the more sincerely congratulate you upon that situation since I learn by your kind letter that there are hopes that your new duties will not deprive Botany altogether of your important services-nay that there is a prospect that your benedictism will be the means of aiding you in your good botanical intentions toward me.-If you will however take the advice of an experienced man of matrimony, you will do well to do, what you mean to do together in that line as soon as possible, for fear of interruptions incidental to your new situation after a certain number of moons.

I have neither received the letter you allude to from Professor Hooker, nor the package you kindly forwarded to Mr. Mortimernor your third number of the Flora [89] all which I am most sincerely desirous to receive. There is one thing which I regret very much, that by your removal from New York it will be possible that I shall lose the pleasure of seeing you on my journey to that 


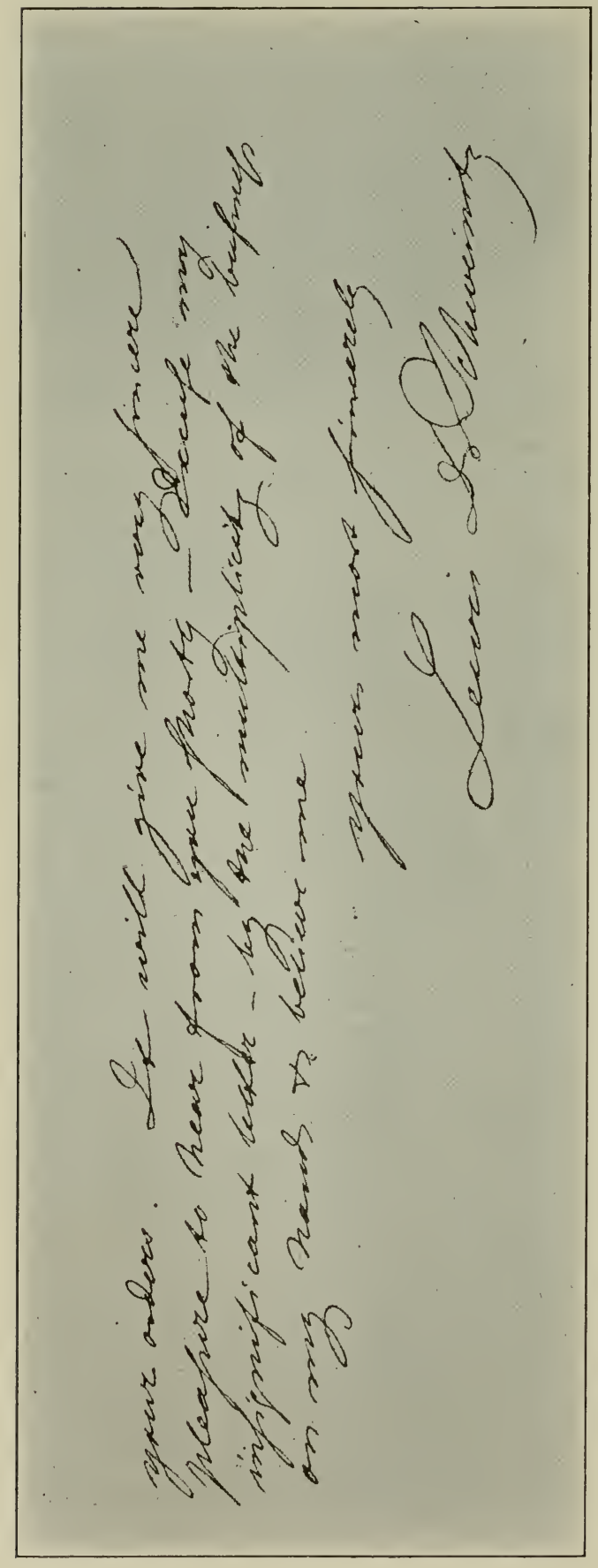

place in spring. I shall at farthest by the Ist April have to embark there for Europe, hoping to return before the close of the year. This circumstance will cause me to lose one whole year in mybotanical studies, but ป will I hope enable on me to augment my $\approx$ means considerably 仓 altho' my journey $\leftrightarrow$ being of an official kind will not leave : me much time for scientific purposes. in If I however can be $\vec{\circ}$ of any service to you  Germany (my stay in Engld \& France \& will be very short) I $\dot{m}$ shall be at your or$\dot{0}$ ders. It will give me $\vec{s}$ very sincere pleasure to hear from you shortly-Excuse my insignificant letterby the multiplicity of the business on my hands \& believe me

Yours most sincerely

LEWIS D v SCHWEI- 


\section{Torrey to SChweINitz}

\section{West Point, Jan ${ }^{y} 7$ th, I 825.}

My dear Sir,

Your letter of the 5 ult. came safely to hand after being a full week on the road. I hope you have by this time received the letter from Professor Hooker, together with the package of books from the same gentleman. A few weeks since a friend received for me at the Custom House in New York, a package from Mr. (now Dr.) Greville, which inclosed one for you. The latter I directed to be left at the house of Mr. Mortimer, \& I expect it has before this time been safely received. Also the 3 rd No. of my Flora [89], which I sent you long since.

The pleasure I hope to receive by a visit from you in the spring, will be mingled with regret that I shall immediately after be deprived for a season of your most delightful correspondence. Do, my dear Sir, make your stay in Europe as short as possible.But above all, leave not our country without letting me see your face. If it is not convenient for you to visit West Point, I shall certainly see you in New York. Perhaps you will lose little in Botany by your absence from America, for you will enjoy very great opportunities to collect specimens of plants abroad. You must remember your friends \& never neglect an opportunity of collecting a duplicate for me! Probably I shall trouble you with a commision or two-particularly with a package for the illustrious De Candolle-for you surely cannot think of visiting Europe without making a journey to Geneva.

My principal object in writing to you at this time, is to beg you will give the Lyceum your last determinations of the Carices. We have completed the Ist part of the Ist vol. of our Annals, \& intend taking up the greater part of the two or three next Numbers with your Historia [7I]. You know that several new species have been discovered by Dewey, $\&$ that in the last number of Silliman's Journal the gentleman has written largely on them [19]. In the number now due, he will have another long paper.-All these will, I suppose, make a few alterations necessary in your Mss. Besides we beg you will make a list of those species which you think should be figured. Several species may be put upon a single plate, 
$\&$ thus, perhaps, all the new or rare ones be represented upon six or seven plates. If you could have a few drawn at Bethlehem, upon an 8vo-size, Mr. Halsey will endeavour to do some of the restbut he has too little leisure to draw the whole. One of Dewey's n. sp. in the last no. of Sill. [19] is the one we have called C. longirostris-I forget his name, but you will easily recognize it. You will oblige the Society by writing either to Dr. DeKay or to Mr. Halsey on the subject, for they wish to commence the printing immediately. You may send a few.corrections of the Mss. (if any are necessary) at once.

I have just looked over the narrative [4I] of Maj. Long's second expedition.-It is tolerable-though there is quite too much of it. But they determined, before they set out, to write two volumes! This I know-for I was to have accompanied the expedition.

You have made the most of the lean herbarium they collected. Indeed I think the appendix [69] is the most valuable part of the book-Are there any duplicates of the new species?

I am in great want of the following plants.

Potentilla hirsuta

—- supina

Ascyrum stans

Caltha parnassifolia

- dentata

_- flabellifolia

Scutellaria incana $M u h l$.

- Zapania lanceolata

Scrophularia hirsuta Muhl.

?Herpestis cuneifolia

Draba arabisans

Dentaria heterophylla
Polygala fastigiata Nutt.

—_ brevifol[ia]

Glycine umbellata

Aeschynomene hispida

Hedysarum laevigatum Nutt.

Astragalus carolinianus

Lactuca hirsuta Muhl.

Mikania pubescens

Kuhnia eupatorioides

- Critonia

Cineraria heterophylla

Orchis integra Nutt.

__ maxima

Any of these which you can furnish me with would be highly acceptable. I intend soon, however, to make out a complete list of my desiderata \& shall furnish you with a copy of it. I am particularly deficient in Southern Syngenesia.

At this moment I am very much engaged with our semi- 
annual examination.-It lasts the whole of this month.-Every day, from 7 A. M. till 5 P. M. except one hour for dinner.

In great haste,

Your sincere friend

JOHN TORREY

\section{SCHWEINITZ TO TORREY}

My dear Sir

\section{Bethlehem January I6th I 825}

Your obliging favor of the 7 th instant came safely to hand \& caused me the most lively pleasure as I had begun to despair whether mine had reached you or to doubt whether my old Carolina friend Macon's [*] pennyworth of savings policy displayed contra West Point might not have the effect of bringing me in to disgrace with you under a suspicion of being one of the conspiracy. I assure you, however, I am not of their council, altho' I very seriously object to the furious method of a semiannual consumption of a whole month in examinations, which deprive you of all scientific leisure unles these examinations be followed as I hope they are by an adequate resting time of another month.

With great pleasure I acknowledge the receipt of the two packages from Hooker \& Greville \& of the 3 rd No of your Flora [89] per Mr. Mortimer, on the last day of the year. I have made a shift cursorily to study thro' the latter \& am highly pleased with it. A few species only that I possess from the regions you embrace are omitted $\&$ a number of very judicious reductions have taken place. My time forbids my entering into remarks at length, which would require a longer study than I am, standing on the wing as I do, able to devote to it just now.

I assure you that the hope you hold out that I shall have the pleasure of seeing you at New York before I leave America goes a great way in reconciling me to the deplorable hurry in which I am under the necessity of making my intended Journey outward bound. I have just given an outline of the circumstances which embarrass me to our friend Mr. Halsey (to whom I have written according to your direction) but you being an old and experienced

*[Macon, Nathaniel, U. S. Senator from North Carolina I815-1828. Consistently voted against all internal improvements.] 
husband by this time will be better able to appreciate them. The purpose (viz. that which my duty imposes) of my whole journey, makes it indispensable that I should be at Herrnhut in Upper Lusatia, Saxony, by the 3oth day of May next, while certain events, in themselves highly desirable, but most unfortunately ill timed, to be expected in my family will forbid my leaving home earlier than to allow me to arrive at New York 2 or three days before the Ist April on which day it is evidently necessary for me to embark if I wish to have any reasonable hope left of reaching my place of destination in time. You see, my dear Sir, that under such circumstances all my hopes of having the pleasure of seeing you, which next to the safe arrival of a little girl in my house, I most ardently desire of all things, will depend on the possibility of your calling for me at Mr. Mortimer's on one of the two or three days before the Ist of April-if I succeed in this hope, I shall take it as an omen faustissimum that I shall be further able to propitiate the Sea \& Wind Gods \& the tremendous host of Infernals usually styled Postmasters in Germany in such a manner as to complete my Journey in time to have an odd week for seeing more of Paris (where I have never been) than can be seen thro' the coach windows of a Diligence.

You will, however, be able to judge from the above how little time I can in the best event devote, outward bound, to science \&c.$\&$ that Linneaus, Descandolles, Persoon, \& all the semi \& demigods of Botany holding council ten miles out of my direct route, could hardly justify a deviation of that length. Nevertheless, if I can take charge of anything for you, which does not absolutely require personal delivery, it will give me the most sensible pleasure.

I have proposed to Mr. Halsey - as I have not a moment's time now to devote to Botany (I don't know whether you are aware that notwithstanding my want of abilities \& qualifications I am clothed with some 15 or 20 different official capacities, all of which require some management when about to be suspended for 9 months) tho' without much hope that it will be of material use as regards the proposed publication of my Carices [7I], on account of the lateness of the Idea, to bring with me to New York my whole collection of Carices European \& American for his and your use during my absence. It would at least enable you to become ocularly acquainted 
with the whole-\& I would have no objection to your keeping anything you like, where your own discretion would shew that enough was left me-altho' I should like it best, if you would in that case adopt the Jewish maxim of tooth for tooth \& Carex for Carex. Let me know, my dear Sir, whether my proposal would meet your approbation.

Concerning your purpose of a Joint Crypt. Flora, I assure you I am ready, or shall be after my return, instantly to commence operations, \& one main reason why I wish to see you personally is to chalk out some feasable plan. The Fungi are the only department I feel anything like competency for. But don't forget that my Sum of American ones is already 2000 spec. (more than one half of the whole I don't believe this to be) \& that it will be necessary to develope to the American public the absolutely miraculous concatenation of progressions which they display. To judge by the effect which my own insight into this wonderful system of nature has had upon me, my only fear is, that when once displayed before the eyes of the American people, its attractions \& fascinations will prove so great, as to become detrimental to the commercial prosperity of your Monster of a city, by turning the attention of all from the Canals \& Banks toward the Fungi. I entirely agree with you-as regards Long's se[con]d Journey, except in the value you by way of compliment, see proper to give my attempt [69] to skim some little fat from a truly lean Herbarium. There is almost as much garrulity in the book [4I], as in this letter \& not much more matter. However, what could be expected from so furious a ride thro' the woods, \& Mr. Say certainly deserves praise for the pains he took to save what could be picked up on-a gallop. It grieves me very much that I have not one duplicate to spare of the whole list you mention. But if it is only your wish to see specimens \& examine, I will select such as I have from my Herbar. \& bring them with me leaving them in your hands on Interest till my return. Inform me whether this will answer.

I am with sincere affect. 


\section{Torrey to SchWEINITZ}

My dear Sir

\section{West Point, March I 7 th I 825}

It is nearly two months since I received your last kind letter, in which you give the unpleasant intelligence that an interruption will probably soon take place in our correspondence, to continue perhaps for a whole year! This has made me feel quite sad-for you are my main dependence in Botany-besides being a friend for whom (though I have never had the good fortune to see you face to face), I have formed a sincere attachment. But enough of this painful subject-I have hardly enjoyed a leisure moment to answer your letter before-and now perhaps I may be too lateThis I send to inform you, of my intention to be in New York, (D. V.) on Saturday morning week if I do not hear from you in the interim. I shall call immediately at Mr. Mortimer's where you doubtless will stay in the city. Hoping to see you then, and have a long talk about matters and things in general, I shall make this epistle brief. I cannot help telling you, however, that a young lady was added to our family last week-and that both mother and child appear to be doing well.-It appears, by your letter, that a like event is about, or has already, "taken place in your family - I hope you may be as fortunate as we have been. You must be too much hurried to read any more-So good bye till we meet-

Your sincere friend

JOHN TORREY

\section{TORREy TO Schweinitz}

\section{My dear friend}

West Point, March 3oth I 825 .

How grievously am I disappointed after anticipating the pleasure of seeing you for nearly two months. I took the Steamboat last Friday evening expecting to find you in New York the next day-but having seen Mr. Halsey he said you had not yet arrived.-On Monday I saw Mr. Mortimer who repeated the same doleful information; but he had little doubt that you would be in town by noon the next day!-I had only leave of absence until Monday evening - but I ventured on another day, that I might at least see you.-This pleasure-likewise, was not for me.-A 
thousand accidents \& unforeseen occurrences took place which consumed my time, so that 5 o'clock P.M. (the hour at wh[ich] the Steam boat started) arrived \& I was obliged to leave the city without accomplishing the main object of my visit! But I will not repine.-It is probably all for the best. Will you certainly leave New York before I could get to you? If you will-do, my dear friend not blame me for not managing matters better.-Believe me, my heart is with you \& a day will seldom pass but I shall regret our separation. I pray our merciful God will prosper you in your journey \& return you in his own good time to your family and friends. In great haste (for the Steam boat is coming) I assure you of my deep regard \& sincere friendship.

Yours truly

JOHN TORREY.

\section{Torrey to SchweINITz}

My Dear Sir,

West Point, December-I 825

I am greatly rejoiced to hear, through our friend Mr. Halsey, of your safe return after so tedious an absence. I hope you have been every way prosperous, whatever was the object of your voyage, \& that you will never again be separated from us-at least for so long a time. With the exception of Caricography there has been little done in Botany since you left us. Mr. Halsey has told you much respecting the Monograph [7 $]$. - You will recollect that this work was written about two years before the printing of it was commenced, \& in the interval a great deal was done in N. American Caricog. Prof. Dewey had laboured much, \& so had my friends Dr. Barratt, Mr. Davis, \& others. My materials in addition to what you had accumulated, were very considerable. All these I took the liberty of adding to your Monograph \& wrote the whole over anew, trusting that you would be willing, on your return, to acknowledge me a joint labourer in the work. If I were not engaged in writing a Flora of the Northern States [89], which will embrace most of the Carices in the Monog., I would freely have made you a present of my materials-but I wish to have it known that I have done something, even in the difficult department to which our genus belongs. When I come to the subject of Carices in my Flora, it is not to be expected that I 
shall offer much in addition to what is contained in the Monograph, \& therefore I shall not appear to offer anything original there if it is not known that I contributed pretty largely to the Monog. I have several times been afraid that you would be displeased with the course I have adopted-but I could not bear to see your memoir published in its imperfect state, especially when I had the materials for much increasing its value. You will see how many species I have added from Richard[son]'s appendix to Franklin's [64] Narrative \& from other sources.-These will make up for the species which have been omitted. The latter comprehends all such, concerning which there was the least doubt. You of course will add some or all of these, if you differ from me in your opinion respecting them. I do not say that they are not all new species-but that it is better to reexamine them with all the additional knowledge we at present possess.

This evening I finished the index to the Monog. It contains descriptions of I I 4 species-all of which I think are very distinct. Mr. Halsey has probably furnished you with a copy of No. X. of the Annals, \& also what sheets are finished of No. XI. If not you shall have them without delay. I wish you would send a little note to be placed at the end of the work, $[*]$ stating that it is to be considered as our joint production, \& to be quoted as such-I beg you would not misunderstand me My Dear Sir,- the reason I am so anxious on this subject is chiefly that I do not wish to have it thought, by those who use my Flora, that I have collected no original materials on the subject of the Carices.

* [ At the end of the monograph (Ann. Lyc. N. Y. I: 374) was printed this note:

" Since the return of Mr. De Schweinitz to his native country, the Committee of Publication have been favoured with the following note by that gentleman, which they deem it proper should accompany the Monograph.

"The Monograph of the Carices, in its present shape, differs so essentially from the unfinished materials, which, on my departure for Europe, I confided to my friend DR. TORREY, with a request to make such use of them as he deemed proper, that it would be an act of injustice to that gentleman to consider him simply in the light of an editor. The judicious and elaborate amendments he has proposed, and the mass of new and valuable matter he has added, entitle him to a participation in the authorship of the work. I am anxious, therefore, that the Monograph should be considered and quoted in all respects, as the joint production of DR. TORREY and myself.

Bethlehem, Penn. Dec. 20, I825."] 
I have much to say on Caricog.-but I am in haste-my time is much occupied with the duties of my professorship.-You will be delighted to hear that C. pauciflora has been found in Massachusetts-as well as to see the good things that Richardson found in the Arctic Region [64]. I have many of these last, \& expect daily some more northern species from Hooker. Prof. Dewey continues to publish descriptions of Carices, in Silliman's Journal [I9], \& appears to have extended his original plan so as to embrace all the species of N. Am. I told him he was interfering with us, but he does not think so.-We must not quarrel with him, for he is an excellent man-

I have your Carices in good order \& will endeavour to send them to New York this week, that they may be transmitted to you without delay. My collection is now very extensive, \& the specimens are very perfect. There will be figures of io Sp. to accompany the Monog. in the Annals-They will be engraved by one of our best artists.-

I shall write more soon

Yours in great haste

JOHN TORREY

Rev L. D. Schweinitz

\section{Schweinitz to Torrey}

My dear Sir

Bethl. Nov 2 Ist I 826

Altho' a correspondence to me so extremely valuable \& delightful as that which I enjoy with you, has been interrupted by circumstances beyond my control for a very long time-I flatter myself that there can be no other obstacle to its renewal with you, than that which caused its interruption on my partviz. such a press of duties imperiously claiming the first attentionas deprived me of the necessary leisure. Not indeed, that I could not have found a moment for inditing a few friendly lines-but really, I have been so unremittingly occupied since my return from Europe, that I have till within a few weeks been almost totally unable to attend to my favorite scientific pursuit-from which it was necessary to draw funds, in order to give any kind of value to letters, which would otherwise have been an absolute intrusion upon 
your no less valuable avocations. But I fear-\& if so it admits of no excuse-but an appeal to your generosity,- - that I have not even expressed to you my warmest acknowledgements for the completion of your labors on my raw material of Carices-which has conferred undeserved honor on me-but luckily at the same time made my materials of some value to Botany. Upon two or three species I have, I think, heretofore requested your reasons for leaving them out-I have since when studying the book [89] (for as to studying this year in that of nature during the season of the Carices I was utterly unable to do anything) thought that I discovered them-especially as regards my Carex nigromarginata-I have viz. presumed that the very distinct species so called by me-is the one you acknowledge as $C$. marginata-\& my marginata identical with vestita - which probably is the truth.

In the occasional moments of leisure which I have had-I have begun for your perusal a rather extensive commentary upon your excellent Flora (I hope nothing has intervened to prevent your putting forth the second part shortly-which I most anxiously expect) giving you a full \& explicit account of every thing in the northern states which I have met with, in any degree not apparently noticed in your Flora [89]-and adding as full an account of my southern observations-not occurring in other books--but my progress has been so greatly interrupted that I have not yet made sufficient advances to render it worth while to forward it to you. This winter I hope to be able to do something that way.

My European Journey \& several important accessions independent thereof have greatly increased my Europ. collect. of plants. But a most deplorable stop of any increase of American specimens has taken place. Do pray inform me, whether I can hope to procure some of my desiderata thro' your further kindness without encroaching too much on your time-\& whether our friend $\mathrm{Mr}$. Halsey still preserves his botanical zeal-or is in danger of falling into the snares of mineralogy (I cry mercy to the professors of that honorable Science for my impertinence).

I should besides be extremely glad to get a number of specimens of certain New England Carices for exchange.

I hope, my dear Sir, that these lines will elicit from you some sign \& token of your still taking some interest in me by letting 
me know after so long an interruption whether it is in your power to permit these presents to effect a recommencement of our correspondence-for which I feel a very great longing since I have got over the extra mountains of business which had accumulated \& been raised by my journey.

Pray have you heard anything concerning our friend Le Conte. Since I saw in the public papers an annunciation of the death of his amiable wife-I have not been able to learn where he is.

Accept of the assurance of my warmest \& sincerest friendship $\&$ esteem with which I remain

Yours affectionately

\section{Lewis D v Schweinitz}

P.S. A few weeks ago I received a package of Musci thro' your care-apparently from Mr. Greville. At the same time 2 packages addressed to me, were lost on the road from Philadelphia-which after a great deal of trouble \& expense were finally brought to light \& proved to be Fungi from Dr. Fries at Lund, together with his new System [24], both packages containing the same books \& fungi \& both accompanied with a latin epistle the one to his old correspondent \& amicus delectissimus the other to the Vir doctissime! of the same name and place of abode, whom he conceives a different person. Unfortunately, this double star-is the one of small magnitude known to you as your friend

\section{D V S}

Torrey to SCHWEINITZ

West Point, Decr. I2th I 826

\section{My Dear Sir,}

It was not for the sake of retaliating your unkind treatment to me, that I have thus long delayed answering your last letter.Since it came to hand I have been closely occupied with various concerns, - but as usual I have to confess some neglect. I might have taken an hour to scratch a few lines-but I always have so much to tell you \& ask of you, that I keep procrastinating till I can write a long letter, but after all, am obliged, frequently to send you the hasty thoughts of the moment. Before I heard from you the last time, I was fearful that in some way or other I had offended you-but I was conscious that I had never de- 
served your displeasure. Now I shall first answer your letter \& then talk about myself.

It gives me much pleasure to learn that you are still interested in the Carices. There are doubtless many N. Amer[ica]n species yet to be detected. Indeed I know of several not in the Monograph [7I], such as C. praecox, \&c., besides some that you described, \& which though not admitted, are perhaps distinct species. Prof. Dewey has several of yours that I thought it prudent to omit for the present. Your $C$. nigromarginata cannot be the one called $C$. marginata in the Monog.-nor your $C$. marginata the $C$. vestita of the same. The $C$. nigromarg. I left out altogether though it is described by Dewey [I9], \& the C. vestita I think is the genuine one-Indeed the last mentioned species is too distinct to be mistaken.

The promised commentary on my Flora [89] I shall greatly value. Indeed, the only way to get a perfect work, is for those who are engaged in similar pursuits to concentrate their forces. I shall always welcome liberal criticism on my book, \& take advantage of every hint towards improving the next edition, should another be demanded. The 2 nd vol. I shall get out as soon as I can afford $i$, for by the former vol. I have lost considerably. I have not yet sold sufficient copies to pay expenses, within $\$ 500$ ! I have indeed a publisher who neglects my business extremely, though I paid him a high price for his work.-The book is printed \& sold on my own account. Have you seen the little compendium which I lately published [87]? I will request the printer to send you a copy immediately. It is a synopsis of my larger work, something on the plan of Smith's Compend. Gt. Britn. [8o]. This I lose nothing by-So that I consider myself particularly fortunate!-

I expected you would make great additions to your Herb. by your visit abroad, \& it seems I was not mistaken. If there [are] any duplicates among your specimens, I entreat you to remember an old friend. It will give me great pleasure if I can supply any of your N. Amern. desiderata, \& I think it will be in my power so to do, as I have now some active friends in the Eastern States who are collecting for me. I believe I have the lists which indicate your deficiencies. Mr. Halsey has done but little in Botany since 
you left this country for Europe. Poor fellow, he is obliged to attend to pursuits, quite foreign to science, \& there is a probability that he will very shortly be obliged to seek new employment, as $\mathrm{Mr}$. Allaire, with whom he is now engaged, is narrowing his business so that he will not need Halsey's services. I have long been endeavouring to procure him a professorship-but no good situation has yet offered. He is a fine scholar \& is qualified to teach Latin \& Greek-or almost any branch of nat[ural] history. Indeed he must have a situation, which will enable him to devote his whole time and talents to Nat. Science. His character in unexceptionable, \& his manners are charming.

You inquire respecting Le Conte. He was in New York a long time, confined with a terrible sore leg, but at length he has got about, \& I believe went to the South a week or two since. He has lately given his memoir on the violets [44] to the Lyceum, \& it will be published shortly. I have some severe remarks to make on it.

That package of Musci from Greville was a very long time in New York, owing to the negligence of a friend of mine. I am glad it reached you at length.

I am now busily employed in writing an account of the plants collected west of the Mississippi on Long's exped[itio]n [9I]. The whole will be arranged according to the Natl. Order. I have written much. The first part of the account is now printing in the Annals. You will be surprised to see what curious plants are in the collection-Many which were never before found north of Mexico.

Your faithful friend JOHN TORREY

P.S. I lately heard of a very convenient way of sending packages to Bethlehem-viz. through Mr. Bininger of N. York. He kindly offered to take charge of anything for you.

\section{Schweinitz to Torrey}

My dear Sir

Bethlehem March I I th I 827

This time I am quite sure, that I have the advance of younot having received an answer to my last-altho' I am far from thinking you to blame, well knowing how many avocations you have. But I am extremely sorry that I have not yet been able 
to lay hold of your Compend [87]. It has not only not been sent to me as you directed-but my endeavors to procure it in Philadelphia have been fruitless - \& from the manner in which my Bookseller Mr. Walter promises to get it from New York I very much fear he has misunderstood my directions, tho' I copied the title from the N. Am. review-\& will get me your unfinished Flora [89]. However, I promise myself to be in a fair way of getting it at all events, nay of doing what is still more my earnest desire, videlicet, getting a peep at your own natural self. It is this delightful prospect, which causes me to trouble you with these lines. Somewhere about the $22 \mathrm{~d}$ or $23 \mathrm{~d}$ of this month I hope to be in New York, where I shall have some business to transact, besides seeing our worthy Bishop on board of a vessel in which he is to depart for the West Indies (by the by, the finest chance I have as yet had of getting West Ind. Plants) which will detain me the greater part of the week following the 25th but not so unremittingly as to prevent an attempt of storming West Point, supposing it possible that I could do so \& return to New York in 48 hours. Now you would confer upon me a very great fàvor by writing a letter to me at New York, to the Care of Mr. Jacob Bininger to be by him delivered to me, informing me whether I should be likely to find the only part of the Garrison that greatly interests me ready to admit of such an attempt, \& if so, when \& how it could be most advantageously executed in the week after the 25 th. Please inform me likewise of the address of Mr. Halsey at this time. I trust you will not find anything Arnoldish in the present negotiation \& therefore grant the prayer of your sincere friend

\section{D v SChweinitz}

\section{SCHWEINITZ TO TORREY}

Bethlehem April i 7 th 1827

\section{DR JOHN TORREY}

\section{My dear Sir}

The most pleasing recollections of the agreeable, tho' short time, I had the good fortune to spend with you, would be not a little clouded by the many things I now think I forgot to converse about with you, did I not flatter myself that your kind promise of spending some part of the vacation with me, would afford an 
opportunity of repairing these deficiencies. I trust nothing will turn up to disappoint me in the sanguine hope of seeing you here \& beg you would be so kind as to give me precise notice of your coming a little before, in order to enable me to arrange matters so, that I may be able fully to enjoy one of the greatest pleasures I can anticipate. In the hurry of my leaving you I unfortunately forgot the Index of my Herbarium-which I should be very anxious to get as soon as possible \& regret that I did not mention it to Mrs. Torrey when I had the pleasure of waiting upon her to deliver your packet in the morning after my arrival at New York-as I might then probably have received it before I left the city. I should likewise be much obliged to you if you would take measures to have the Ten Dollars for Schwägrichen [66] paid to my account in the Union Bank \& give me notice thereof.

Concerning the Fungi you were so kind as to give me I beg leave to observe that there are among them five or six new ones, together with a larger number of such as are rare to me \& have not ever been found by myself, tho' I had previously received them from you. You desired me to return you the duplicates where such could be made out-\& I now beg to know whether you wish to have pieces of all those I received from you-or only of those I have determined as new \& whether you are content to wait for them until you come here-or desire them to be forwarded immediately. So small a packet I fear would be liable to be lost. I am glad to find that I can spare you 2 or 3 specimens of our German Sclerot $[$ ium $]$ vaporarium-\& will try to enclose a few of my S. medullare in this letter-which I found in the hollow of some Syngenesious plants in a garden-occupying the place of the medulla. It is rather the largest species of Sclerot[ium] I have met with in this country.

A press of business obliges me to take abrupt leave of you with the assurance of my sincere respect \& friendship \& I hope you will ever consider me

Yours affectionately

L. D. v SCHWEINitz 


\section{SCHWEInitz TO TORREY}

Bethl. Dec 5 th 1827

\section{My dearest Sir}

Let me entreat you - unless for reasons which I cannot divine, you should have resolved to break off a correspondence to me so valuable to afford me the consolation of a few lines. I have already understood that the severe disappointment I met with, by your not coming hither during the vacation-was probably owing to your translation back to New York \& Mr. Halsey informs me, that there you do intend to devote yourself further to Botanyboth pieces of intelligence in the highest degree pleasing to me. I must inform you too, that very soon after the time in which I had prepared my house \& Collections for your accomodation-I was seized during the Botanical expedition I at length undertook without you - with a severe indisposition, which for 5 weeks incapacitated me altogether from doing anything of consequence, from which I however recovered in time to collect considerably of our fall treasures. A very extensive plan concerning Asters \& Solidagos which I intended chiefly for you-was however nearly prostrated again by an interruption which I could not helpduring which the mould got into my specimens \& almost ruined them-but I was further prevented from completing it-by a journey I had to make from Oct 2 to Nov. 3 to Lake Erie-unfortunately too late to admit of much botanical exertion (besides continual rain) but interesting nevertheless on acc't of the Geography of some plants which I had occasion to observe at least in their ruins. In the letter to Mr. Halsey in which I enclose the present-I state to him what I am now able to furnish. I am sensible that my recent collections contain nothing you could want - except perhaps 3 or four to me doubtful things which I shall lay by at all events. Should you, however, observe anything desirable-be sure it is at your comand. But I have always calculated upon going thro' my whole collection with you- \& whenever that is the case nothing in it anyway divisible so as to be satisfactory to you, shall be spared. Permit me to remind you of your kind promise concerning the White Mount[ain] plants-or anything else any way calculated to augment my collection. I have been sorely disappointed in not receiving the European col- 
lect[ion]-promised me \& on the way. I fear it is lost. Dr. Hooker has however sent me his Monograph on the British Jungermanniae [33].

Let me know if you please whether you at present have any botanical plan in view, in which I could assist you. Besides putting all things in order-the one I propose to prosecute next is a review of my whole collection-with an especial eye to your Flora of the North. States [89] \& for the last classes [of] your Compendnoting everything I have knowledge of - from your precinct-which I do not find there.-If I suceed in completing these remarks during the winter, it is my intention to communicate them to you $\&$ to accompany that communication by a transmission for your examination of an extract from my collection of all the specimens upon which my remarks are founded-which I shall beg you to return-when you have made such use of them as they may afford. Please to give me your new direction $\&$ believe me at all times yours affectionately

\section{D v Schweinitz}

\section{TORREy TO SCHWEINITZ}

\section{My Dear Sir,}

New York, April 3rd, I 828

I really do not deserve to be numbered among your friendsso negligent have I been to you for many months past. Time after time have I resolved that I would sit down \& write you a letter, although it should contain but a few lines-yet I have postponed it again \& again, chiefly because I had no sufficient excuse for my neglect-but partly because I could communicate nothing that would particularly interest you. Since last August my time has been fully occupied. The change in my affairs imposed new duties on me- \& from the time that my lectures in the college commenced, until lately, I have had no leisure to correspond, or indeed to attend to anything but Chemistry. At length, however, I am released, \& I am deeply engaged in botanical pursuits. Often have I thought of you, My Dear Sir, as I occasionally peeped into a package of plants (for I kept my herbarium in a room adjoining the laboratory in the Med[ica]l College), or when I turned my eyes towards a pile of unanswered letters, that laid for several months on my table. I indulged the pleasing hope last week that I 
should see you in a day or two, "face to face" \& have a good long botanical talk. I left the city for Philadelphia, with my brother, with the design of visiting Bethlehem before I returned-but circumstances rendered it necessary for me to proceed directly home, disapointed in my fond expectations.

My time, at present, is almost entirely taken up with the arrangement of my herbarium. I have purchased new paper portfolios \& cases sufficient for all my plants-\& have already done much toward placing my collection in a state fit to be used. I think it will be one of the most elegant in our country when it is finished.

Since we last met I have received some fine accessions-Of both indigenous \& exotic plants-I have a large. package from Dr. Scouler, of specimens collected on the N. W. Coast of America, but unfortunately there is scarcely a duplicate among them. When I was in Philadelphia, I examined the collection of plants brought home from Long's 2nd Expedition \& made some notes which I should be pleased to show you, for I find that we differ about a number of species.

You enquire in your last letter (dated Decr. 5th, for which I have yet to thank you!) whether I have any botanical plans in view:-I have several-which I will now detail.

I. The Seacoast of New Jersey has not yet been thoroughly explored. It has only been examined at one or two points, \& these, (with the exception of the neighborhood of Tuckerton) have not been exhausted of their treasures. I propose to spend several days, either alone, or with such friends as I can persuade to accompany me, on different parts of the sea-coast of this State some time in the month of July.

2. I propose to send some person to the coast of Maryland. Dr. Pickering (a very promising young botanist of Philadelphia) thinks he will be able to visit this region the present season. An abundant harvest awaits him-\& he will collect enough for all his friends. This part of the coast will probably afford many Southern plants, wh[ich] have not yet been recorded as extending so far North.

3. My next plan is pretty extensive.-Many of our botanists are exceedingly desirous of obtaining plants from the regions west 
of the Mississippi-\& Some of them, with whom I have conversed on the subject, have ageed to contribute towards defraying the expense of sending a person to collect specimens.

Mr. Nuttall thinks that we may procure a collector on very reasonable terms in England or Scotland \& he promised to bring out with him, in the Spring, such a person, if he could find one of the proper description. I propose that we take the specimens of him at a certain rate,- say at five or six dollars the hundredthe specimens to be divided into lots when the collector returns. He can bring home living roots, \& seeds, which will be a sufficient remuneration for his time \& labour, independent of what he can make by the dried specimens,--for the country to wh[ich] we propose sending him, abounds in new \& most interesting plants. If the person were quite poor, we might contribute each a few dollars, in advance, for wh[ich] we can receive an equivalent in plants. Tell me what you think of this \& the other plans.

Mr. Halsey is pretty active in Botany, but he is unable to do so much as he desires, from want of the needful. Poor fellow, he has a large family to support, \& his only income is a pitiful salary wh[ich] he receives from one of the banks. I would rejoice to see him snugly settled in some professorship. $\mathrm{He}$ is well qualified to teach Natural Hist[or]y, Greek, \& Latin, \& the higher branches of education generally.

Do write me soon, \& let me know what you are doing \& whether I shall have the pleasure of seeing you soon in N. York.

Yours most sincerely

J. TORREY

\section{SChWEINITZ TO TORREY}

My dearest Sir

Bethlehem April in th i 828 .

This happy moment puts me in possession of your kind favor of the $3 \mathrm{~d}$ instant-\& I embrace a moment's leisure to answer it immediately, in order to assure you that it gave me the most lively pleasure, excepting only that passage of it which informs me of the frustration of your plan of calling here \& thus deprives me of one of the greatest enjoyments I long for. Do, I most earnestly pray you, contrive in some of your vacations to grant 


\section{The Correspondence of Schweinitz and Torrey}

me a few days-I know it would prove a matter of the utmost importance to me, \& might afford me some chance of useful interchange. I am glad to learn, that you are arranging your herbarium-don't forget me \& my desiderata in so doing. I must confess I am almost in despair about my botanical exchanges just now. Within the last three weeks I have with great exertion made up large packages for Dr. Hooker, \& Mr. Greville \& forwarded them to Mr. Bininger by the Brunswic[k] stage. They have not arrived I hear at New York, \& are probably lost. I fear as much for a package of several hundred North Carol[ina] plants forwarded since to our friend Mr. Halsey accompanied with about 500 Spec. mostly new Fungi, which he was to share with you -because I hear nothing from him about their arrival. I am this day forwarding another package to Baron Lederer \& feel very ill at ease to think all these things lost which have cost me so much time \& labor to collect. The communication of your botanical plans was to me in the highest degree interesting. If it was possible to give me notice a week or two beforehand \& to arrange a point of meeting, it would be one of the most agreeable things I can imagine to accompany you in the excursion on the Jersey shore. The coast of Maryland is I think quite a new field.If possible, may I put in a claim to join in the fruits of that expedition \& still more in that west of the Mississippi-? I would be most happy to be considered a contributor to the plan in a pecuniary way to the extent of my means.

The latter part of the winter I have been employed as much as my duties allow in writing a new descriptive Synopsis of my Fungi [76] - but have not yet got thro', tho' nearly, with the monstrous genus Sphaeria. It is my purpose to continue-\& finish it next year, with drawings of all \& every new one. What is to become of the work when finished I have not yet determined.

During the whole of last year I have been very unfortunate in my desire to encrease my collection. Not one of the foreign supplies promised has come in $-\&$ at the best season for doing something personally-indeed during an attempt-I was seized by an indisposition which utterly incapacitated me. When recovered\& a fine prospect arising - my duty obliging me to travel to the North West Corner of the State on Lake Erie. Untoward cir- 
cumstances deferred this journey until late in October-so that vegetation was entirely gone.

Do me the favor to enquire of $\mathrm{Mr}$. Halsey concerning the arrival of my package, which left Easton on the 3Ist March-\& I advised him thereof by letter \& permit me once more to beg you \& him, to try to do something for me. Knowing, however by my own experience how difficult that is-when duties occupy so great a portion of time--I can readily account for it - if you find it out of your power. Within a few weeks I expect to go to Philadelphia - if possible I should be very glad to become acquainted with Dr. Pickering. Can you furnish me his address?

Excuse these hasty lines, designed only to express to you my extreme joy at your resuscitation-after so long a silence-\& my warm desire to participate in the plans you propose. Believe me

Yours most sincerely

L D v Schweinitz

\section{TORREy TO SCHWEINITZ}

My dear Sir

New York, May ist I830-

Yesterday Maj. Le Conte read me a letter which he had just received from you. I was rejoiced to learn that you expected to spend a few days in Philadelphia in the middle of this month, for I hope to be there about that time myself. Perhaps we can make arrangements for a trip to Quaker Bridge and examine the early vegetation of that interesting region. I will endeavour to be in Phil. on the evening of the I6th inst. so that we can take the Tuckerton Stage early the next morning, and arrive at the Bridge in time to collect many plants before night. I must return to Phil. early enough to take the steamboat for Trenton on the 2oth, for I am engaged to give a short course of chemical lectures at Princeton College, which will commence on the 2 Ist inst. There will not be many rare plants to find in the pinesbut if we only found one it would be worth while to go.

Ever since our lectures closed at the Med[ica]l College (March Ist last) I have been occupied in arranging my herbm. It was necessary to put my materials in order before sitting down to write the continuation of my Flora [89], and I have hardly made 
the arrangements for resuming this long intermitted work, when I must postpone the subject again for a few weeks till my business at Princeton is closed. I have often told you before, that I must attend to Chemistry, because I get my bread by it, and I love it very, very much. Yet I love Botany more if I may judge by the comparative zest with which I pursue the two studies. Perhaps, however, if Botany were my task, and Chemistry were my play, matters would be reversed.

I have many things to say to you, but cannot tell them to you now, as I must close my letter in time for Maj. Le Conte to take it with him to Philadelphia.-When we meet there we shall have, I hope, some long talks respecting our favorite science.

Since I commenced the above I have seen Major L. C., who informs me that he will not set out for Philadelphia till Monday; so that I can write to you a little more in detail.

With regard to domestic botanical news, I must be very brief. The number of votaries of Flora in N. York is now reduced to two, viz. Mr. Halsey and myself. Maj. L[e] C[onte] has given up plants, he having gone so far as to announce that he will never write another botanical paper! Cooper has deserted our ranks and has presented his whole herb ${ }^{\mathrm{m}}$. to the Lyceum. At present he devotes himself to the study of ornithology and organic remains. Halsey, poor fellow, is so much occupied with matter foreign to botany, that he can do but little for the science-at least his studies are so loose and interrupted that he cannot undertake anything like a monography or Flora. For myself, I hope to do something effectual before autumn next-perhaps prepare a half vol. of my 2nd vol. [89] for the press. I am constantly receiving fine collections from various quarters-tho' since I saw you last winter, I have had few accessions of indigenous plants.

I know of no botanist at the North who is actively engaged but Mr. Oakes. He is a hard-working naturalist, and will certainly produce something creditable to himself and the country in the course of a year or two. He is preparing a Flora of $\mathrm{N}$. 
England-but does not intend to publish it for several years; Some Monographs will probably appear first.

Dr. Lewis Beck has not yet given to the public his promised work on the Ferns \& Mosses of the United States [8] - nor do I think it will appear very soon. I do not see how it is possible that he can be qualified for so difficult a task as the one wh[ich] he has undertaken. The only essay he ever made of his powers in CRYPTOGAMOPHYTOGRAPHY is his paper on the "GrevilleaNUM" published two or three years ago in Silliman's Journal [9], a moss which turns out to be the Timmia Megapolitana! His catalogue of Ferns is by no means complete, and that of the Mosses, very imperfect. He made out the latter from Schwägrichen's book [66], marking every species said to have been found in the United States.-

By the way, speaking of mosses, I have now in my possession, a beautiful collection of about 300 mosses collected by Drummond in the British possessions of $\mathrm{N}$. America and named by that botanist under the immediate eye of Hooker.[*] The plants are beautifully put up in three bound volumes with a manuscript catalogue \& index. A few Sets are for sale still, I believe, in Scotland. I shall take immediate steps to procure a copy-the one which I have in my study has just arrived for a gentleman at the North \& is intrusted to my care.

Have you heard of Hooker's new work on the plants of British America [34]? It includes all the plants collected by Richardson

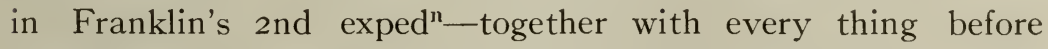
published concerning the botany of the region mentioned. The Ist No. in toto with numerous excellent plates has been received by one of our booksellers, but we are all too poor to purchase itespecially as in doing so we must subscribe for the subsequent no ${ }^{\text {s, }}$ of wh[ich] there will be $\mathbf{2} 2$. The price of each is $\$ 6$. ! The plants are arranged according to the natural order-\& there are many

*[ Hooker, Sir William Jackson. Notice concerning Mr. Drummond's collections, made in the southern and western parts of the United States. Jour. Bot. I: 53 (footnote). I834.

. "Musci Americani, or dried specimens collected in British North America, and chiefly among the Rocky Mountains, during the Second Land Arctic Expedition, under the command of Captain Sir John Franklin, R. N., by Thomas Drummond, Assistant-Naturalist to the Expedition.' In 2 volumes, quarto."] 
new species.-Hooker has also commenced a very useful work called the Botanical Miscellany [ıо]. There is an excellent work entitled The Magazine of Nat ${ }^{1}$. History [50] edited by Loudon, in London-It comes out every two or three months, is quite cheap \& contains much botany.-You probably have seen the enormous, but most excellent book by the same editor, entitled "Encyclopedia of plants" [49]-comprising an account of all plants cultivated in Britain, together with the natural species-a single vol. of nearly $\mathrm{I} 300$ pages, very fine print, large 8 vo.- -with I, ooo cuts in excellent style, of about $\mathrm{I} \odot, 000$ species. The work was prepared by Lindley, who has filled it with interesting matter-The price is $\$ 25$ or $\$ 26$. Lindley is preparing an introductory work on the Natural Families of plants [45]. He has lately pub. a Synopsis of the British Flora [47], containing description of the phenog. plants and filices of Gt. Britain, in nat. orders.-Hooker has ready a British phenog. Flora according to the Lin. Syst. [32].

The plants \&c. sent home by Dr. Gates are worth but littlethey comprise a few things which he collected very early last spring near N. Orleans, and some given to him by a collector who picked them up in the same district. Le Conte and I divided them by lot among our subscribers. Almost the only interesting articles among them are a new (or perhaps Mexican) species of Campanula, allied to C. simplex - and some good specimens of what I take to be your Thelephora coccinea-Syn. fung. car. inf. I find it to yield a beautiful scarlet to alcohol or water, which may be used as a dye, that resists both acids and alkalies. Dr. G. lost the whole of last season by severe and long protracted sickness, but he will remain another season in the country, and believing himself to be now acclimated, he hopes to be successful in making large and valuable collections before next autumn.-

Yours truly,

JOHN TORREY.

Torrey to SCHWEINITZ

My dear Sir,

New York, April 26th i83I.

It is a long time since I had the pleasure of receiving any communication from you, though I hear that you write occasion- 
ally to our friend Halsey. I know not why you have ceased your correspondence with me,--for I always valued it, \& found it very profitable. My last letter to you was written about a year ago.I then proposed that we should make an excursion to Quaker Bridge together, \& knowing (or rather understanding from some of our friends-I forget who) that you was to be in Philadelphia about the middle of May I proceeded there, in the expectation of seeing you-but you had left the City.-Perhaps you never received the letter to which I allude.-And now my dear Sir, whatever may have been the cause of the long interruption in our correspondence, I hope it may be renewed, for I have turned again to my botanical studies with great zeal. Since I came to New York my time has been very much taken up with the duties of my station as Profr. of Chemistry in the Medical College-but my business is now arranged so as to allow me leisure to prosecute Natural History with advantage. If you will allow me to say a few words more about myself I will inform you that I have been writing for the 2nd vol. of the Flora of the Northern States [89], so long laid aside. I have also been arranging my Herbarium, \& making myself acquainted with some branches of botany which I had too much neglected-particularly the Natural Classification, now apparently about to supplant \& throw out of use, the Sexual System of Linnaeus. We have no other botanists besides Halsey \& myself-for Le Conte can hardly be called a New Yorker\& Cooper has relinquished the study of plants.-Of course I have but little botanical news to send you-

You have heard that Dr. Eights, whom the Lyceum sent out in a vessel bound for the S. Seas, returned last fall without having accomplished much, for it turned out just as several of us suspected, that the Expedition was destined, not for discovery, \& for scientific purposes-but to catch seals!

Dr. Gates, sent out by an Association (of which I believe you a member) to the countries west of the Mississippi, has done as yet but little better, for he lost nearly a whole year by sickness. Early last spring, while recruiting at New Orleans, \& while still very feeble, he received the offer of a professorship in some literary Inst $^{\mathrm{n}}$. in Mobile, which he accepted. He has lately written to Cooper, informing him that he collected last year about 9000 
spec $^{\mathrm{ms}}$. of plants, in different parts of Alabama, \& that we may expect part of them very soon. He promises also to collect all in his power, during the present season,- - so that we may yet get something for our $\$ 650$.

After so much about unsuccessful collectors you will not perhaps wish to hear of a new proposition-but I will venture to mention it to you. Mr. Drummond, the celebrated collector \& muscologist, who accompanied Franklin \& Richardson on their 2nd Exped $^{\mathrm{n}}$, has just arrived here from Scotland, bringing me letters from Drs. Hooker \& Greville. Mr. D. is about proceeding on a journey to the West of the Mississippi for the express purpose of collecting specimens in all the branches of Natl. History for sale to any who chose to purchase them. He expects to spend several years in this country, \& to explore all those parts which have hitherto been little or not at all examined. Many gentlemen in England \& Scotland have engaged to take full sets of all that he collects \& Dr. Hooker has fixed the price for the plantswhich tho' rather high is not extravagant for rare new ones- \& viz. $£_{2}$ per hundred. He will allow American botanists to make selections of such plants as they need. You may calculate to what an extent Mr. D. expects to collect, when he has sent out to New Orleans, two tons of paper. Mr. D. asks nothing in advance but he would like to form some estimate what number of specimens would probably be taken in America.-He will leave here in a few days \& [if] you would like to engage two or three hundred specimens please let me know. Dr. Hooker has kindly sent me a set of Mr. Drummond's mosses, collected in Franklin's 2nd journey-about 280 species-many quite interesting. [*]

Have you seen Hooker's Flora Boreali Americana [34]? Several copies of No. I. are in our shops. The work is dreadfully expensive-4to. 20 plates each No. for $\$ 6.50-$ There will be 12 nos. It is beautiful. I have a copy. Carey \& Lea ask $\$ 7.50$ per No.

I am printing an American $e^{\mathrm{n}}$ of Lindley's new work on the "Natural System of Botany" [46] \& will give an appendix containing the North Am. genera with the no. of species as far as now known, arranged according to the improved nat. orders. \& now my dear Sir, I will ask a favour of you-which is a list of N. Amer.

* [See footnote, p. 245.] 
genera of fungi \& the no. of species (not their names) belonging to each-also the authority for the genus abridged.

\section{I remain}

very truly yours, JOHN TORREY-

Rev. L. D. Schweinitz

Bethlehem

Pennsylvania

\section{SChWEINITZ TO Torrey}

\section{Bethlehem May 4th I83I}

\section{My dearest Sir}

I can truly say, that the reception of your kind favor of the 26th ult. (which unaccountably took place only last evening) gave me as much pleasure as pain. The former on account of the delight of recommencing a correspondence with my most valued botanical friend in America \& the latter on account of the interpretation you might conceive my long silence \& especially my neglect of your kind letter of last year liable to. Alas! I was not aware that you were ignorant of the cause of the latter-which from the time I received yours to within about two months past entirely disabled me from any exertion whatever. I left Philadelphia in a hurry on account of the violent breaking out of an indisposition I had felt for some time coming on \& my chagrin was not a little augmented by finding at home your letter, which apprised me of the disappointment I had unwittingly prepared for you, which at the same time was as great a one to me. But I was soon incapable of feeling the regret, for besides some alarming symptoms of another kind I became extremely debilitated \& with little interruption experienced a depression of spirit such as I had before been an entire stranger to, until the commencement of December. Scarcely had that left me, \& enabled me to resume my duties \& my studies, when it pleased God to visit me with still more serious bodily complaints by which until the comencement of March I was strictly confined to my room. During this tedious spell however I had every reason to be thankful that no relapse of mental depression took place. On the contrary I was enabled to be active with my pen $\&$ among the rest completed 
the Synopsis of the American Fungi [76], containing descriptions of about 1500 new species \& remarks upon the whole number of $3000 \mathrm{Am}$. species as yet observed by me. That I did not forget you, my dear Sir, I hope to be able to prove to you-for among the rest I put by for you upwards of 200 species of very beautiful specimens of Surinam plants $[*]$ with such determinations as I have been able to make out- $\&$ the box now stands ready to be forwarded to you by the first opportunity that occurs, as I requested Mr. Halsey to inform you, when about a month ago I had the pleasure of receiving a letter from him, the first voice from any botanical friend after my indisposition. I trust that you will now excuse my apparent neglect. My health is not yet by any means reestablished on a sound basis-accordingly about the middle of this month I shall commence by the advice of doctors a long journey \& have chosen the westerly direction, proposing to go as far as the state of Indiana It is by no means improbable that. I shall return by way of Lake Erie \& in that case hope to have the pleasure of seeing you some time in July. I have prepared myself if my strength admits to botanize on this journey with as much zeal as possible. Having now given you some idea of the last lost year- $\&$ the candid assurance that your kind letter proved to me a most encouraging omen that my hopes of being fully reinstated among the rest in my botanical enjoyments, permit me both to answer it \& to mention some other matters. In the first place concerning my Synopsis [76]. It was my intention to forward it imediately for publication to France or Germany (tho' somewhat appalled under present circumstances by the well known adage Inter arma silent litterae!) But during my last visit to Philadelphia a fortnight ago (where by the by I again missed seeing you as I had been led to hope by Dr. Pickering) I was so urgently requested to submit the work to the Philosophical Society, to be published as their next volume, that I left it in their

*[ There seems to be no record of the source of the Surinam plants placed by Schweinitz in his herbarium and distributed by him to correspondents. There is no doubt that they were sent from Surinam by Dr. Constantin Hering (I800-I 880), who soon afterward settled in Philadelphia and became one of the founders of homeopathy in America; but some or all of them were probably actually collected by Christoph Weigelt, who was associated with Hering in the exploration of Surinam, and who died there in I 828 . - J. H. B.] 
hands \& have since received assurances that it would be published so as to appear at the end of the year. If it is so finally determined, I shall be glad as I would prefer its being published in America. Upon the expressed wish of Mr. Halsey I have yesterday forwarded to him, my scrawl from which the Synopsis is composed-in three bound manuscript books. I am thus deprived of the means of correctly answering your request of giving you a list of the N. Am. Genera with the number of species-\& beg to refer you to Mr. Halsey - who will I trust let you have the perusal of my books (written carelessly indeed both as to latinity \& handwriting) \& thus enable you to extract them yourself. In my work for publication I have made some few alterations in the arrangement \& adopted some new genera established by Fries in his recent publication on the whole vegetable kingdom[24] - which I am very sorry I did not send on-as it would be highly interesting to you. The number of species however is almost entirely the same-except that I have here \& there omitted a few, which did not appear sufficiently ascertained. Nothing will be more eagerly expected by me than the book you are publishing on the natural orders.-As regards the Fungi-the perfection of the System is really admirable \& I do most sincerely regret not having sent on to you Fries' work [24] which comprises not them alone, but the whole of the Cryptogamia. No opportunity will offer before my journey; otherwise you should still receive it. Tho' you say that you have little of bot[anical] news to communicate I was unusually gratified by what you do impart. Can there be a more pleasing piece of news than that you have resumed the publication of the 2d Volume of your. Flora [89]? On my return from the westward, if it be not too late, I should like to send you for inspection everything that my Herb. contains, that would be of use in making it complete. Let me know if you would wish it. The hopes you hold out concerning Dr. Gates-are gratifying. I hold three shares in the association. LeConte \& yourself are appointed to act for me. A German adventurer took me in last fall upon a similar plan. His name is Voltz-but I have not heard a word from him. The proposals of Dr. Drummond are indeed of a different kind \& so tempting, that notwithstanding impoverished circumstances I cannot help requesting you to secure for me the 
right of getting two hundred species from him on the conditions proposed, begging you kindly to undertake their selection for me. I have seen Hooker's work [34] at Carey \& Lea's. It is however quite beyond my means.

As you have lately arranged your Herb.-I hope you have found some trifles for me.-Indeed, my dear Sir, permit me to beg that you keep me in good remembrance, when anything especially American, falls in your way. I trust when you receive the Surinam plants, you will give me credit for my own remembrance of you. Anything foreign will be acceptable likewise. Should I be lucky in my western expedition, you may rest assured that the second specimen of anything I can procure is regularly laid by for you. God grant that my health may be so improved by my journey as to render me able to botanize. My legs are still very feeble, but I am accompanied by my cousin [nephew], who has a little smattering of botany. I propose to forward the box with Surinam plants to you with the direction to be called for at the Easton Stage office kept by James King, No 7 Cortland Street, \& if I can find an opportunity before I leave home I will put into the box Fries, Syst. Orbis vegetab. [24]-for your perusal.

This moment I am interrupted by a very acceptable letter from Mr. Greville, Edinburg, who informs me that he has forwarded to me the plates of his work on the Filices [37], addressed to your care by a Mr. Davidge of Baltimore. Should you have received that parcel I beg to request that you may be so kind as to deliver it at Mr. Van Vleck's, our minister, Dutch Street, as within a fortnight I shall have a fine opportunity to get it from him.

I remain yours most sincerely

Lewis D v Schweinitz

\section{Schweinitz to Torrey}

Bethlehem July 3 Ist I 83 I

\section{My dear Sir}

On the 2 Ist instant I have happily returned from my ten weeks tour in the western country which proved very beneficial to my health (altho' unfortunately during the last days I have again caught a violent cold, which threatens in part to deprive me of those benefits) \& extremely delightful in every respect. It has 
not indeed been productive of many new plants - of the few I have I propose to send you a list-but nevertheless full of botanical enjoyment, by giving me a very satisfactory Idea of the Botany of the regions I passed thro'. I hope you safely received the collection of Surinam plants which I forwarded to you just before my departure. On my arrival I found the valuable work on the Ferns from Greville [37] which you have kindly forwarded \& beg to express my thanks to you. Permit me to enquire whether anything further concerning Dr. Gates' collection has transpired-or whether you have anything on hand for me, as on the 12 or 13 of Aug. my friend Rev. W. H. Van Vleck of New York proposes to leave there for Bethl[ehem] \& would favor me with his kind attention to anything you might think proper to send. In hope of soon hearing from you I remain yours

most respectfully

LEwis D V SCHweinitz

\section{TORREy to SCHWEINITZ}

My dear Sir,

NEw York, May I4th I83I.[*]

A day or two after I dispatched my last letter to you, \& before your most welcome epistle was received, the parcel for you from Dr. Greville was left by some unknown person at my house.

I took it with me to the city for the purpose of leaving it at Mr. Van Vleck's who I supposed resided in that Green Street (for we have two streets of that name!) which is near his Churchbut no Mr. Van Vleck was to be found there, \& as I had some business further in town, I left the bundle at Mr. Thorburn's seedstore till I should return. Mr. T. immediately offered to forward it to you safely, \& I concluded to leave it in his charge, but now I am in doubt whether I did right! I think I will call on Mr. Van Vleck tomorrow \& request him to take care of it. You are probably the only botanist who at present owns a copy of this rare \& costly work [37]. There are two sets in one of our bookstores but the price is so great that none of us can afford to purchase them. I have, however, the prospect of obtaining an uncolored copy from Greville, in exchange for a quantity of our native

* [Mailed August, I83I ; see next letter.] 
plants, on terms wh[ich] are easy to me. The Authors have figured but few N. American ferns. Their Woodsia Perriniana is exactly the plant which I have called Hypopeltis obtusa-the Aspidium obtusum of Willd. \& Muhl.! Some specimens by mistake found their way among a collection of West Indian [plants] made by a M. Perrin. One was sent by me to Sprengel several years ago, who named it Alsophila Perriniana. Another, named according to Sprengel, was transmitted to Hooker-who has given a very good drawing of it in his work. The plant is, however, not a native of the West Indies at all, \& is doubtless the species of Aspidium named by Willd. \& Muhl. obtusum. The indusium is not upon, but beneath the sori, as in Woodsia, but I thought it differed so much from the other Woodsiae that it was proper to make a new genus for it. But upon the whole I am now inclined to follow Hooker in altering the generic character of Woodsia so as to receive the present species \& its name must be W. obtusa.

I congratulate you on the completion of your Synopsis of $\mathrm{N}$. American Fungi [76] \& hope you will urge the publishing committee of Phil. Society to have the work printed with expedition. Mr. Halsey will doubtless allow me to use your rough copy of the Manuscript for the purpose of making out the list of genera that I requested of you.- The promise of the loan of Fries' work on Cryptogamous plants [24] I am very thankful for, \& I hope you will forward it to me as soon after your return as may be convenient. It shall be carefully preserved \& returned in a short time. Please inform me in your next letter what is the price of the book, \& the best method of obtaining it.

I sincerely hope, My Dear Sir, that your : ntended journey may be the means, by God's blessing, of restoring you to perfect health. I did, indeed, hear that you had been in poor health, last summer, but it was my impression that you had long since recovered \& had resumed your scientific pursuits. Hence the remarks in my last letter, which I very much regret caused you the least pain. You will pardon them, however, (I trust) when you know that they were elicited by the sorrow I felt, under the impression that so good a friend as you, had for unknown reasons seen fit to suspend his communication with me. 
When I had written thus far, I was interrupted by the postman's bringing in your letter of May Ioth, informing me of the transmission of the promised box of Surinam plants, \& of Fries' much desired work [24]. Surely I have another proof of your enduring friendship, in thus remembering me in the hurry \& occupation necessarily attendant on the setting out upon a long journey. You will be much in my thoughts till you return, \& I pray may be restored sound in body, \& richly laden with the Lord's grace, to your happy family.

In less than a fortnight $\mathrm{I}$ expect to start for Princeton in $\mathrm{N}$. Jersey where, (I believe I informed you) I am engaged to give a course of lectures on Chemistry, to occupy me ten weeks. I shall be in a good botanical region \& not far from the famous Pine barrens. Three active young men are to accompany me as pupils, \& I hope to make them very useful to me in preserving a large quantity of botanical specimens.

Your request respecting the collections which Mr. Drummond expects to make, shall, (D.V.) be faithfully attended to. I shall order duplicates of the very species which I desire for my own Herbm. \& I very much doubt whether I shall be able to obtain more than the number you mentioned. At any rate it seems quite out of the question for me to go beyond 300 species unless I can tempt him with some of our New England Mosses in the way of exchange; for Mr. D. was quite surprised to see so many kinds from that part of the country in my collection, that he did not meet with in his journey to the North, \& he wished much to obtain a large supply of them.

\section{I remain, My Dear Sir}

Yours respectfully \& affect[ionate]ly,

J. TORREY

\section{My Dear Sir}

New York, August I3th I83I.[*]

On my return to the city a day or two since, after an absence of nearly three months, I found your acceptable letter of the 3 Ist ult. It gives me sincere pleasure to learn that you have been preserved during your journey \& have returned safely to your

* [Inclosed with the preceding letter.] 
family-yet this pleasure is mingled with regret that you have since suffered from a cold which may deprive you of the benefit derived from travelling. I hope, however, that you will soon be restored to perfect health.

The box of Surinam plants came safely, as I believe you are informed in the letter accompanying this-(which was written before I left the city \& not forwarded thru' negligence).--If not, be pleased to accept my thanks for your very liberal present. The parcel from Dr. Greville I left in care of Mr. Thorburn of this city, who said he transacted business with you \& would forward anything to you-with pleasure.

Since my return I have seen none of my New York friendshaving been incessantly employed in putting my house study in order, \& in answering letters-of course I have not had an opportunity of enquiring about Dr. Gates' plants. It is my inten. tion, however, to call today on Mr. Cooper (who conducts the correspondence with Dr. Gates) \& learn from him whether the boxes have arrived.

During my stay at Princeton I was diligent in collecting plants, but my research for new species was not successful. The region is very much like that of Bethlehem, as far as I can judge. The few rare things which I found shall be shared with you as soon as I can arrange my collection which will be next week, if I am spared.

My visit to the pines of $\mathrm{N}$. Jersey in May last was quite a pleasant one-but I found no rarities.-If possible I must make a trip to the sea coast of N. J. in two or three weeks-as I have never visited that region-at least not south of Squam inlet. Could you not make it convenient to go with me? I would meet you at Tuckerton at any time that you might appoint.

In a few days I hope to complete a small collection for you.In the mean time remember me if you are arranging your last collections, \& believe me

Yours most respectfully

JOHN TORREY

\section{Torrey to SCHWEINITZ}

New York, August 26th I83I.

My dear Sir,

Two or three weeks ago I left for you, at the house of Mr. Van Vleck in this city, a letter \& small parcel (containing Fries' work 
[24]) which, I suppose, were received by you in due time. Since then I have made another visit to the country with my family, so that my botanical \& other studies have been interrupted.

I am now finishing my edn. of Lindley's Work on the Natural System of Botany [46]. The Appendix concerning which I have written to you before is partly in type, but the printers proceed very slowly. I have obtained your mss volumes on $\mathrm{N}$. Am. Fungi [76] from Mr. Halsey \& have made out a list of the genera,but not until I had sent off the vol[ume] of Fries'. In "Cohors 6 (Hyphomycetes)", series 2, 3, 4, 6, \& 7 are not named-is this an intentional omission?

I have made out a list of the Musci \& Hepaticae, in which I should differ, perhaps, from some of my friends, respecting the arrangement \& number of Species-but it seemed to me better to include none but such as are well ascertained.-The order Algae is very small-that class of plants having received but little attention from our botanists. I should take it as a very particular favour, My dear Sir, if you would furnish me with a list of the species which you have found, or know to inhabit N. America, named according to Agardh's Systema Algarum (3). I expect the number is so small that it will not require much time to make it out.-Yet I would not trespass even this much on your hours of study, were not the object so important.

I suppose you have seen the 2 nd No of Dr. Hooker's Fl. Bor. Amer. [34] which proceeds nearly through the Caryophylleae (following the order of De Candolle) - The estimable author informed me last May that he had just finished the 3rd No. wh[ich] concluded the Leguminosae. This work throws much light on N. Amer. botany \& will be of great service to the one who shall write a general Flora of our Country.

We have but little botanical news here-Indeed I stand almost alone in the Science-for Mr. Halsey is so much occupied with business that he cannot prosecute his favorite study with any advantage to himself or others. - I told you before, that Mr. Cooper does not attend to botany any more, except to look over a new work when one appears. Le Conte can hardly be called a New Yorker-for he is rather a cosmopolite. There is scarcely any one who takes an interest in my labours, $\&$ were it not for 
my friends at a distance, I should feel but little pleasure in my work.

This season has not enriched my herb[ariu]m very much-A few parcels of plants have, indeed been received, but none to equal your fine collection of Sumatra [Surinam] specimens. It would greatly delight me to reciprocate this favour-but you must wait till opportunity offers. In the mean time I will lay aside for you such plants as I fall in with \& which I think you would like to have.-I have not yet got into my hands a collection from Kentucky which was in the city six weeks ago, $\&$ has gone to Albany, where it was sent with the gentleman's baggage who brought it for me from Lexington-I hope to have it in a very few days, when I shall be able to spare you some of the duplicates which I am told it contains.

In my list of $\mathrm{N}$. Am. genera I have put the name of the author after each genus.- but in the catalog. of Fungi from your Mss [76] I found few of the genera with any name appended. I suppose it will answer, to state, that the system followed is that of Fries, $\&$ that the genera which are adopted are his, except those marked with your own name. In the hope of hearing from you soon, \& hearing that your health is established, I remain. My Dear Sir

Your obliged Servt. \& friend

J. TORREY

SCHWEINITZ TO TORREY

Bethlehem, Sept 24th I 83 I

My dear Sir

By my nephew Mr. Eugene Freeauf who accompanied me on my late western tour, I take the liberty to send you a few specimens picked up under the disadvantages I labored under. The Koeleria \& Bromus I should be very glad to have your opinion on. At the same time I forward to you my full list of all the plants I noticed on the tour, merely as I conceive it might interest you for a moment \& beg you may return it to me-You will likewise find in the parcel the remarks which a renewed attentive study of your excellent Flora [89] as far as Triandria has suggested to me-which I beg you to accept \& to make what use thereof you please or none at all. I have further put in a few hasty remarks on the 
Plants known to me as naturalized in the U. S. Do you think a piece of the kind [73] would be useful \& acceptable in Silliman's Journal? If you think it worth while I will communicate the continuation of my remarks on your Flora, as I proceed gradually in the study \& comparison.

You cannot think how glad I should be to procure specimens of such of your plants as I have not seen. Such are to the end of Triandria Blitum maritimum-Agrostis clandestina - Aira pumila-Panicum longifolium \& the true Aira compressa. Indeed if Mr. Freeauf could bring anything from you or Mr. Halsey on his return it would give me the greatest pleasure. My health is gradually mending, but I have not recovered my speech-so that I am unable to speak publicly. My friends leaving here a day sooner than was anticipated I am deprived of the fine. opportunity of writing to you more at length. If you can without inconvenience show any attention to my nephew, who is not without scientific interest, I should be much obliged to you. Believe me most sincerely Yours

\section{LEWis D v SCHWEINITZ}

\section{TORREy TO SCHWEINITZ}

My dear Sir,

New York, Sept. 29th I83I

On my return this afternoon, from Princeton, (where I have been spending a day or two) I found the parcel of plants \& letter brought (\& left also probably) by your nephew, Mr. Freeauf. Thinking it probable that he is still in town \& that I shall find him tomorrow at Mr. Van Vleck's, I closed a parcel of plants which had been laid out for you nearly two weeks. This very small collection I hope will contain a few that have not yet found a place in your herbarium; but a number of the specimens are only sent for the purpose of being examined by you, \& not in the expectation of their being such as are new or rare to you-

I thank you much for your "Remarks" on my Flora [89], \& also for the list of plants found in your late journey. On your Remarks, I will take the liberty of sending you a few observations, if there should be time before Mr. F. (if he is still here) leaves the city; and I will also send a list, taken from your Catalogue, of such species as I desire particularly to possess. 
Your kind letter of the 8 th inst. is also still unanswered. It came rather too late for me to use the list of N. Am. Algae which you took the trouble to make out at my request, but it will be of use to me nevertheless, in preparing my general list of N. Am. plants wh[ich] I never lose sight of. I should be greatly pleased if I could have an opportunity of examining the salt water Algae of our Seacoast. It is astonishing that scarcely any of our botanists have collected them hitherto-no department of our Crytogamia has been so much neglected.

You remarked, that you had not seen the 2nd No. of Hooker's Boreal Flora [34]. It will give me pleasure to loan it to you for two or three months, after the first of November next-from which time, until the beginning of February I can give only occasional attendance to Botany. As you observe, this Flora would have been far more useful to you than the splendid work on the Ferns [37] sent you by Dr. Greville.

The contents of the parcel sent by your nephew are highly interesting to me. Valeriana pauciflora I almost despaired of ever seeing. Your Koeleria from Ohio seems to be very near one which Dr. Pitcher brought me from Fort Gratiot, a specimen of which I believe you have-

Your Bromus occidentalis I cannot distinguish from one of the varieties of $B$. ciliatus which grows in this neighborhood. After much exam ${ }^{\mathrm{n}}$. I am convinced that the Bromus canadensis, ciliatus Eo pubescens are all one species.

Hydrophyllum or Phacelia-This seems to belong to the former genus, - and near $H$. - - differing however in its denser clusters of flowers, \& in being hairy. It is probably a new species.

Viola alba L.v.S. Is it distinct from V. Muhlenbergii? Perhaps the peculiarity of its appearance is owing to the situation in which it grew.

Salix-? I will not pretend to name any unusual species of this genus until I make a regular study of the collection which I have been making for several years, $\&$ which is now very extensive.

Sept. 30. I don't know that there were any other specimens in your parcel which required a particular examination-except perhaps a Rumex, which I think must be $R$. verticil[latus]: \& the Koeleria which I now find is identical with a species sent to me 
from West Chester by Dr. Darlington in I 827 \& which I have called $K$. subspicata.

Oct. Ist. Your nephew called to-day \& communicated to me the agreeable intelligence that he would not leave town until the middle of next week. I am much pleased -with him, having found him exceedingly intelligent \& communicative. You, my dear Sir, was the chief subject of our conversation. I was much gratified to learn that upon the whole your health had improved \& I hope you will ultimately be restored to sound health-but above all it is my prayer that you may be submissive [to] our Heavenly Father, \& be prepared for all his holy will-

Oct. 2nd. I have been occupied part of this day in separating a considerable collection of Alabama plants wh[ich] we have at length received from Dr. Gates.-As nearly every thing wh[ich] he transmitted was in the botanical way, it was necessary to divide the collection in to as many shares as the whole number subscribed for-making no less than 60-Three of these are yours, \& they are already packed up, together with some specimens on my own account, your 3 mss. vols. on Fungi [76], \& a volume which Mr. Halsey sent to me-

It is hardly necessary to mention, that the shares were assigned to the subscribers by lot. There are some very good things \& several wh[ich] appear to be new. I am to make out a list of all those drawn by our friends here, of wh[ich] you may have a copy if you please; but I have made no remarks on those which are in your parcel as they are your property \& you have a right to name \& publish what you find new among them. You will find a most remarkable plant allied both to Gerardia \& Seymeria, but quite a new genus, [*] first discovered the present year in Georgia by Capt. Le Conte. There is another collection to come from Dr. Gates, which shall be divided as soon as it arrives, \& your share transmitted without delay-

Oct. 4th. I find that it will not be possible for me to send by the present opportunity my observations on your "Remarks", alluded to above-My ed ${ }^{\mathrm{n}}$. of Lindley [46] is just printed \& you shall have a copy soon.

Very truly your friend \& servt.

J. TORREY. 


\section{TORRey to SChWEINITZ}

\section{My dear Sir,}

New York, Feby 3rd, I832.

Although I am excessively occupied with my College duties, \& my head is crammed with chemical ideas, I often turn with a longing eye to my Herbm. \& wish that I might again range the fields \& climb the mountains in pursuit of my favorite productions of Nature-Not that I do not love my present employments-I do love them, \& eagerly engage in all the duties of the laboratorybut Flora had my affections before I was acquainted with any of her sisters, \& the first love, you know is the strongest. I begin however to see the end of my present course of lectures \& after they are finished for the season, I hope to take up Botany in earnest.

Your favor of November last with your remarks on Gates's plants \& a paper on naturalized plants [73] came to hand in due time.-The last was communicated to the Lyceum \& referred to the Committee of publication. I have not time at present to reply to your obs[ervatio]ns on Gates's collection-but in the Spring (D.V.) I wish to communicate with you on the subject.

By Mr. Siedel I sent you my copy of Hooker's Fl. Bor-Amer. [34] except the plates of No. I. - -which I hope you recd. in safety.I have now the $3 \mathrm{rd}$. No. which is chiefly filled with the Leguminosae \& it is at your service if you wish the use of it for three or four weeks-

Two or three days ago I was greatly delighted at receiving a box of books from Dr. Martius of Munich. Being occupied at the college, a friend transacted the Custom House business for me, \& sent the box to my house-On opening it, it was found filled with parcels for yourself, the Lyceum \& the Academy of Philadelphia-with only three volumes (a very coarse mutilated Copy of Travels in Brazil) [83] for your humble servant! Even these three books I am unable to read, as they are printed in the German language-but we have an English Translation of the two first vols. in the Lyceum. I am glad that there is something for youbut I wish the Dr. had sent me something for the \$18.02, which I paid for freight, duties \& other expenses on his "sending." How does it happen that transportation is so high in Germany? The 
bill is nearly $\$ 6$ for expenses to Hamburgh.-Dr. M. has sent the Acad. a fine Atlas \& set of plates, intended to illustrate his \& \& Spix's Travels [83] - to the Lyceum he has presented a copy of his Nov. Gen. \& $S p-p l-B r a z i l$ - - a beautiful \& valuable work [5I].

As your parcels were necessarily opened at the Custom house I took the liberty of peeping into one or two bundles of your plants, but they did not appear to be very interesting-there were many old German acquaintances among them, \& I expect they are the scrapings of the Dr's. duplicate herbm.

In your last letter you held out to me the hope that I might reap some benefit from the revision of your Herb. which you expected to undertake the beginning of the present year. Allow me to remind you of my list of wants which I sent you some time since.

The parcels from Munich are left with Mr. Bininger, in Broadway, with the request that they may be forwarded to you by the first good opportunity.-

I have received nothing new since the winter commenced, except a Splachnum from Quaker Bridge which my friend Dr. Greene of Boston collected last spring. I inclose you a fragment of it-the Species wh[ich] it most resembles is S. tenuifol[iu]m of Hook. \& Tay[lor]. Musc. Brit. ed. [-] [38] but it differs in some respects. I have not yet compared it with the specimens collected by Drummond in Arctic America.[*]

Have the Carvills forwarded you a copy of my edn. of Lindley [46]? One was left for you in their Charge more than a month since

$$
\begin{aligned}
& \text { Yours very truly } \\
& \text { JOHN TORREY }
\end{aligned}
$$

Schweinitz to Torrey

Dr John Torrey, New York

Bethlehem, Feb I4th I 832

Dearest Sir

Your favor of the $3 \mathrm{~d}$ instant gave me the most lively pleasure $\&$ not the least part thereof was caused by your declaration of constancy to your first scientific love. With all possible esteem

* [See footnote, p. 245.] 
for her Sisters \& their acknowledged beauties I confess I can hardly forgive any one's forsaking Flora's delightful service entirely, while I do most sincerely rejoice in the fact that a faithful attachment to her can \& often does subsist, whilst her devotees are actively engaged in the more substantial employment of her richer sisters.

I look forward to your remarks on Gates' plants with no small desire-by the by - are we not to expect some fresh supply from that Gentleman. The last remittance tho' not extraordinary, was still extremely valuable.

The copy of Hooker's two first numbers [34], which you so kindly lent me, was duly received $\&$ has been assiduously studied by me. I regret (besides the want of the plates of the first no.) that I suffered myself to be deterred from my first intention of copying out the whole (for since then I have copied a much longer \& less useful affair) until the time you have so kindly allowed me for the use of it has expired: I am however very glad to be able to prove to you my punctuality in returning by the good opportunity which offers to send it you. Tomorrow a gentleman with whom I have become scientifically acquainted during his winter's residence here, viz. Dr. Saynish of Nyk [New York] proposes to go to Nyk \& has promised me, to take charge thereof. He will make a stay of a few days only-if you can spare it-I should most eagerly embrace your offer of perusing the third No.-provided you could send it to me by that Gentleman-\& would do my best to return it shortly to you. I have not received the Copy of your edition of Lindley [46] - tho' most eagerly looked for. Indeed I have deferred a study of the natural families for which I had prepared myself - until after its receipt as it will doubtless aid me essentially. Dr. Saynish has promised me to call at Carvill's \& try to get the volume. I have actually gone thro' my collection as I stated to you in a former letter-but I found the project of combining a selection of your desiderata with the object I principally had in view not so practicable as I thought, \& have therefore resolved to make that selection the cause of a new progress thro' the whole. The list of your desiderata however appears to me to be taken exclusively from my list of plants obiter observed during my western journey only. On this account I am about making out 
for you a new list of all my American plants, in which however I mark those of which I cannot spare any, for want of a duplicate. - I shall send you this \& beg you to mark such of the rest as you would be desirous to see $\&$ have at all events.

Your annunciation of the arrival of packages for me from Dr. Martius, was wholly unexpected. I can very deeply sympathise with you on the disappointment the contents of the box caused you-from similar misfortunes which I have experienced-\& am much obliged to you, that you have probably saved me one, by your peep into my parcels-for I should certainly have expected something more valuable than I fear the scrapings of Dr M.'s Herb. may prove, altho' Dr. Saynish tells me, that he has seen the whole of Martius' Brazilian collection, \& that they are upon the whole extremely imperfect \& wretchedly preserved. However every little helps.

My friend Mr. Bininger has just informed me that he is about forwarding these packages to me very soon. Pray, my dear Sir, let me bear my proportion of the truly enormous charge upon the box \& inform me of what that amounts to.- It can only be owing to mismanagement that the German transportation comes so highor perhaps to that spectral ghost the Cholera which has possessed the European governments \& makes them do everything in their power to prevent the passage of packages of every kind. I have lately received Journals, which were perforated in every direction (as all my letters regularly are) by the purifying chisel \& so imbued with a smell of Vinegar of Four Thieves, that I can hardly stand the perusal of them.

The little Splachnum appears to me very interesting. Be sure to inform me whether it agrees with your arctic specimens of Drummond. By the by, has that gentleman actually commenced his operations in this country-\& is there any hope of participating in the harvest?

The entire restoration of my health (tho' alas not of my youthful energy in climbing fences \& stooping \& marching, the want of which will be a great drawback on my exertions) with which I flatter myself, gives me hopes of doing more this year in Botany than of late years. I have not heard from Mr. Halsey for a long time-\& will beg to remind you once more to be so kind as to let 
me know-if you do-where Capt. Le Conte may at present be found. If in any vacation of your duties you could make it possible to stay some weeks, days or even hours only at my houseit would give me the sincerest pleasure.

I remain yours most sincerely

LEWIS D v Schweinitz

P.S. I have two packages of plants for England lying ready for more than a year-but have not yet been able to devise a way of forwarding them to London with safety-as I am told Capts. of Packets refuse to take charge of such things. How do you manage these matters?

\section{TORREy to SchweINITZ}

My dear Sir,

New York, Feby. 29th I832-

I was quite vexed with myself when I called at Dr. Johnson's to see Dr. Saynish, to find that he had just left the city for Bethlehem. I had something for you which I intended to have left with him on Monday even[in]g last, but, a severe indisposition confined me to the house. It was my impression that Dr. S. was to remain some days more in town-or I should certainly have strained matters to have made him a call. My mind was so occupied with College \& Chemistry that I postponed the business a few days, when I knew I should be at leisure. I shall call shortly at Mr. Bininger's, or Mr. Van Vleck's to enquire about another opportunity for your town-

The 3rd. No. of Hooker [34] is quite at your service for a month if you wish it,--but next Autumn you may have it againuntil March I833! I understood from a former letter, that you had the Ist. No. of this work, or I should have sent the plates of it with the others but it seems you wish to see them. They shall be forwarded by the next opportunity. I will also send you the Ist edn. of No. I. which scarcely differs from the 2 nd ed. except in being printed on smaller paper. If it is of any use to you, I beg you will keep it. I know not why the copy of Lindley's Introduction [46], which I prepared for you so long since, has not reached you. It was directed to be sent to Mr. Bininger's store. Perhaps Dr. S. obtained it from the Carvills, if it still remained in their hands. 
I hope, my dear Sir, that you will soon be able to look over your collection for the purpose of selecting for me, according to your kind offer. When your list of duplicates arrives I shall immediately forward you a list of the species which are still desiderata with me-

You doubtless received the parcels from Dr. Martius in good time. I hope you found something in them worth your acceptance. - The books, of course are valuable-But the plants, from the hasty glance which I took of them, seemed to be rather indifferent. You are right respecting the cause of the expense of transportation in Germany-Mr. Cuthbert, the American Consul at Hamburgh, informed me in a letter that the box was subjected to numerous detentions at the various quarantines established for the Cholera. You need not trouble yourself about the charges on your portion of the box, for they only amount to about $\$ 2.50$, which is less than you must have paid on some of the parcels transmitted to me-

I have looked over Drummond's Arctic Mosses since I wrote last, \& my impression is that the Splachnum of Quaker Bridge is quite distinct from the $S$. angustatum. It will probably turn out to be a new spec. We have all neglected botany this winter in New York. but as the spring will be here tomorrow I hope we shall have our feelings enlivened, \& resume the study of plants with renewed zeal.

The address of Capt. Le Conte at present I cannot give you without some doubt. It is probable that he is residing with his brother Lewis LeC. in Riceborough, Liberty County, Georgia. A letter sent there, intrusted to his brother's care will no doubt reach him soon.

If you will send your parcels for England, to New York, \& direct them to Mr. Bininger's Store, I will have them forwarded to London by the next packet. If the Capts. are waited on personally, they will take charge of small bundles. We have a young merchant in our family who cheerfully does all such business for me.

By the next private opportunity I hope to write you more at large.

Your obliged \& faithful friend 


\section{SchiveInitz to Torrey}

My dear Sir

Bethlehem March 29th 1832

Your exceedingly agreeable communication of the 29th ult. ought to have been answered long ago-\& would-but for a new \& severe attack of my complaint-owing, I have reason to fear, in a great measure to the failure of Spring coming on, \& that unheard of severe weather which has with us kept alternating with warmth. I trust the worst is over $\&$ have found considerable relief from my complaint for a few days past-so that I can again breathe with some freedon.

How much I deplore that you were prevented from forwarding what you intended for me-pray leave anything of the kind at Mr. Van Vleck's or Bininger's - \& it will reach me. As regards the 3d number of Hooker [34] as it is now too late to request its perusal for the present, I shall be much obliged to you to send it in autumn so that I may have it during next winter, begging by all means, if you can spare it, to add the Ist Ed. of No. I which you so kindly offer.

But I can hardly adequately express to you the gratification \& instruction, which the Copy of your Ed. of Lindley's Introd[uction] [46] (which Dr. Saynish bro't me) imparted to me. I fairly devoured it-\& think the work truly excellent. For the first time I have thereby been enabled to acquire an insight into the natural System \& was delighted by it.

For some time I have been busily engaged in making out a list of the duplicates I can make out of my collection for you. But it is a work of some considerable magnitude. Tho' I do not precisely know whether you wish me to include European plants,-I have added a list of all, of which I can afford specimens, except such as are very common. Their number greatly exceeds that of the American duplicates I can offer you-as I naturally exclude from my list of these the numerous ones, which I know you are familiar with-or which I owe to your kindness.

The parcels from Dr. Martius-tho' they did not furnish to me more than about 40 species new to my collection, where [were] nevertheless valuable because in many instances they contained better specimens than I had before. He holds out a promise of 
sending Brazilian plants-when his work on them shall be finished. The few specimens however which he has sent are exceedingly imperfect. A better addition to my collect[ion] was made about the same time by about 300 Cape plants which cost me $5 \$ \&$ were procured thro' Dr. Saynish.

I am much obliged to you for your directions as to Capt. Le Conte. Just before I received y[ou]r k[in]d letter an opportunity offered for forwarding my two packets of plants to Englandwhich I embraced-but have since much regretted it-for I have learnt such particulars about the person, who took charge of them, that I am not without fears about their safe arrival.

One thing considerably cheers my mind-it appears to me, that the very particular affection of my lower extremities, which has so much impeded me for a year or two past-is wearing off-\& I begin to think that if this was overcome all my other complaints of the chest \&c. might possibly give way likewise. No kind of occupation gives me greater relief than botany.

Believe me my dear Sir your very obliged \& faithful friend

\section{LEWIS D v Schweinitz}

P.S. If I have correctly understood your former letter you stated that the Copy you received of Dr. Martius travels (83) was incomplete. It was not, till a few days ago, when about to send my copy to be bound - that I discovered - that the second volume is double with me. Should this be the part wanting in yourspray let me know, that I may sent it to you.

\section{SCHWEINITZ TO TORREY}

My dear Sir

Bethlehem, April i2th, I 832.

I am well aware, that in forwarding to you the inclosed long promised lists I) of American 2) of European plants, of which on a strict examination of my collection I can furnish you with a specimen-I am imposing no slight task on your eyes-by the microscopic \& perhaps illegible characters in which it is written. I was induced to press the whole together in so small a space in order to be able to forward it to you by a mail at an early day, to enable you to take time to mark all those which you desire to have-because you will readily conceive that it will require considerable 
time for me to get them out for you. But, if they or any of them shall be acceptable to you-I can promise every one here noted \& desired by you-unless I have inadvertently in any case made a mistake. In the labels which I shall give those you wish-I will carefully note the place $\&$ the source from which I have derived them.

In the first list-all the underlined species are such as $I$ have named \& there are not a few among them, whom probably you will not be able to admit as new species. Nevertheless I was desirous of letting you see what I have so designated, subject to future correction-Probably I may have likewise mistaken others. In every case your opinion \& remarks will be truly acceptable. I presume there are not a few-which I have heretofore sent you. All such-\& indeed in general all that you do not absolutely want-I shall be glad to keep-as I have been very strict in naming in the list every species - of which I can at all afford a tolerable specimen. The same is the case, tho' not so generally, as regards the European List. In the American all those which I owe to your kindness \& all those which I know to be common \& in your collection are left out-which has greatly reduced the number. In the European list very common species are likewise omitted. Having been disappointed in my hopes of cramming the whole second List on one sheet-I was tempted to fill up the blank part of the new one I had to take by a list of my American desiderata, arranged according to the authors from which they are derived, leaving out in each succeeding author's list all those already recited in the preceding ones. I need not say that if you can provide any of these-or other new things-how much I shall be obliged to you-for it is dreadful how large a number is still wanting. I only beg to add that the European plants are chiefly good specimens, perhaps to be sure mostly known to you. But you will at least see my willingness \& desire to contribute what is in my power. My tropic plants rarely afford duplicates-except the Surinam of which I have already sent all I had.

I wonder whether you have seen that most extraordinary \& impertinent publication which Rafinesque has just issued-on every possible subject, under the title of Atlantic Journal [63]. He is doubtless a man of immense knowledge-as badly digested as 
may be \& crack-brained I am sure. His short reviews of 23 recent works-among which your ed. of Lindley [46] is likewise paradedare truly comical. I have some notion of competing for the splendid prize of Twenty-five Dollars he offers, to be paid Nota bene-in pamphlets of his own manufacture \& specimens of plants from the same laboratory-for the best synopsis of U.S. Phaenog. plants-under the highly characteristic condition-that not a single one already described or published in Europe \& Am.- (meaning by himself) shall be omitted. Do pardon me, dear Sir, for the impertinence of sending you these enormous lists \& believe me most sincerely Yours

Lewis D V Schweinitz

P.S. I am happy to say that by the Lord's mercy I am almost entirely recovered in my health-\& do not doubt that Spring, if it come at all-will complete my entire restoration.

\section{SChWEINITZ TO TORREY}

\section{My dear Sir}

\section{Bethlehem May i 7 th 1832}

Some weeks ago I took the liberty to trouble you with a very voluminous list of my duplicates-together with a letterwhich I trust came safe to hand. I did not expect an answer immediately as I am aware your time is so much engaged-but had requested a friend who since has gone to New York to give you a call \& to learn whether it has reached you. He however forgot to fulfill his promise. I therefore now write to you in order to say, that about the I2th of June, Deo volente, I hope to be in New York for a few days \& should be very much obliged to you, if you would kindly by that time leave a line at Rev. W. Henry Van Vleck's, No. I4 Dutch Street, informing me of the time $\&$ number where I could conveniently to you, call upon you. My duties will call me to divers places at a distance from New'Yorkso that I should be extremely glad to be able to arrange an interview before hand.

You will learn with satisfaction, I am sure, that it has pleased the Lord perfectly to restore my health excepting only a stiffness in the lower extremities which greatly impedes me in walking -but which I shall probably never get over, as I begin to con- 
sider it either the forerunner or the lieutenant of an hereditary affection of the gout. Botanical exertions out of doors are greatly impeded by it-while experience teaches me notwithstanding that they are the best alleviations of the evil.

Excuse my troubling you with this short letter \& believe me with sincere regards yours affectionately

\section{D v SChWEINitz}

\section{TORREy TO SCHWEINITZ}

\section{My dear Sir}

\section{New York, May igth I 832}

I received your letter of the $I 7$ th, this morning, \& that of the I2th ult. (containing the elaborate catalogues which made me feel how indolent I am), came also in good time. Indeed, on looking over my file, I have just discovered that even a third favour remains unanswered! Your second came soon after the preceding one, \& I was making preparation to answer it, when I received yours of the I 7 th. I have nearly completed marking in your list of North American, those species which I should like to possess. I am ashamed that so many of them are still wanting in my herbarium. Many are marked because I have bad or doubtful specimens under their names. Still more ashamed am I, that I can do so little for all the trouble I occasion you. Of that long catalogue, embracing the N. Am. plants which you wish to obtain, scarcely any are among my duplicates. I shall however, preserve the list \& give you the first choice of what falls into my hands-\& I sincerely hope that some of the many nets which I have spread, will gather for me what will not only replenish my own herbm. but enable me to assist materially my friends. The list of European plants I cannot compare with my herb. till I return from Princeton. It requires more time for me to make the examination in consequence of my collection being arranged according to the Natural Method, while your catalogues correspond with the Linnaean System.

It affords me sincere pleasure that I may indulge the hope of meeting you next month. It is true I have an engagement at Princeton during June \& July, but I expect to leave my family in New York, \& to visit them nearly every week. I am not occupied 
on Saturdays \& Mondays, \& conclude my lecture on Friday in time to reach New York the same day to tea-so that if you could manage to meet me on some Friday evening, Saturday, or Monday before I2 o'clock-or on all of those days,-or what is much better, make my house your home during one of my visits in June, I shall (D.V.) be able to enjoy your company. The only difficulty which I perceive, is, that the I2 of June will occur of Tuesday. Perhaps, however, a day or two before or after this date will not materially interfere with your arrangements.

The 2nd vol. of Dr. Martius' \& Spix's travels [83], I have learned, through Dr. DeKay, belongs to the Lyceum of Nat. History, whose set is defective that volume-There were three sets in the box, \& I made the blunder in dividing them for their several owners, so that we will thank you to forward it by the first good opportunity.-Perhaps you can bring it on yourself in June next.

I must trouble you with one more subject before I close my letter. Two or three years ago-perhaps longer-Dr. Greville informed me that he placed in the hands of a Mr. Davidge, who said that he was about leaving Scotland, for America, a copy of his Algae Britannicae [26]-but the work never came to hand. I have written to Dr. G. several times on the subject, but he says that he can obtain but little accurate information about the gentleman. who took charge of the package-tho' he ascertained that he did eventually embark for this country. Dr. G. says that by the same person, he sent to my care a set of impressions of Icones Filicum [37] as well as a letter for you. I have some recollection of receiving for you the plates alluded to-but accompanying them there was nothing for me that I observed. Did you get the plates-\& also any numbers of the Algae? If I did not forward you the parcel perhaps you received it from some other quarter-\& perhaps also you can tell me something about this Mr. Davidge that I may write to him \& get my copy if he yet has it.

Hoping to see you completely restored to health in the course of a few weeks. I remain My Dear Sir, Yours faithfully JOHN TORREY

Please return the inclosed list when you have done with it. 


\section{SCHWEINITZ TO TORREY}

Bethlehem May 24th I832

\section{My dear Sir}

I was not a little delighted yesterday by your letter of the I9th ult. (unable as I am to account for the circumstance that almost all letters I receive from New York, whence the mail arrives daily \& goes thro' in I day \& night-are four days old) $\&$ for fear you may go to Princeton too soon I hasten to answer it. I greatly deplore that it will be impossible for me to arrive at New York before the I2th of June (being Tuesday) which will deprive me of the pleasure of meeting you that week-with a certain prospect that on Saturday \& Monday following, which days are those I could otherwise hope for that desirable event, I shall be absent from New York in the prosecution of my duties. It is however possible that I may be able to prolong my stay until the $23 \mathrm{~d}$ of June, before I leave the city altogether-and perhaps circumstances may occur to detain you in town on the 13 th or I4th when I shall doubtless be there. At all events please to leave a card for me at Mr. Van Vleck's No. I4 Dutch Streetwith your address designating the number \& street-\& likewise that of Mr. Halsey if you conveniently can. I shall certainly bring the odd volume of Dr. Martius [83] with me to New York \& deliver it to Dr. DeKay.

In answer to your enquiries concerning the Algae Brit. of $\mathrm{Mr}$. Greville [26] which you have not received-I can only say, that nothing of that kind has come to my hands \& that I think you must be under a mistake as to the time they were sent ( 2 or three years ago or perhaps longer) if at all connected with Dr. Greville's set of impressions of Icones Filicum [37], which I certainly received thro' your kindness. By recurring to your letters, I find that on the latter subject you wrote to me under date of May I4th $I 83 I$-that the parcel for me cont[aining] the Icones had a few days before been left at your house by an unknown person-\& that you had placed it in the hands of Mr. Thorburn to be forwarded to me-which was accordingly done \& I received it shortly after my return from Indiana. Dr. Greville's letter to me had come to hand some time before per mail, \& ship-marked-so that it does not seem to have been brought by a friend-tho' so stated 
in the letter, without however naming him. I am truly glad to see by your returned list-that I shall be able to furnish you so large a number of plants-but you will no doubt allow me time to go thro' my collection at leisure to make out the parcel,- - which will be impossible I fear till after my return from New York.

Dr. Pickering has just informed me that my Synopsis of American Fungi [76]-is very nearly printed. I trust by the time I get to Philad. on my return, it will be entirely so- \& that I shall be sure of getting a number of copies presented to me by the Philosoph. Soc. But if they allow me but two copies-one is yours \& shall be forwarded as soon as procured.

I am just attempting a negotiation with Collins' administrator at getting from him some of the loose packages of plants-if it can be done without extravagantly paying for them-for the price which I understand is asked for his own collect[ion] of American plants-is exorbitant \& at all events greatly exceeding my means. The less I am able to exert myself by collecting plants from nature - the greater my zeal becomes of increasing my collection (which with Cryptog.--is now nearly 20,000) of dried specimens. Two packages from Wallich I have been informed are on the way for me.

With the most ardent wish of not being disappointed in meeting you personally, I remain Yours affectionately

LEWIS D v SCHWEINITZ

\section{TORREy to SCHWEINITZ}

\section{My dear Sir,}

NEW York, June I 8 th I 832 .

Your letter of the 24 th ult. I received in due time. I entertain some hope that I shall meet you on my next visit to this city, which will be on the 22nd inst. if the Lord prospers me. I do not see how I could break off from Princeton earlier in the week than Friday morning, after my lecture, \& by taking the New Brunswick stage at Io A.M. I can reach New York by 6 P.M. If you can possibly remain until the time stated, it would afford me great pleasure to talk over with you a variety of matters, which cannot well be discussed in letters. If you must pass on without seeing me, I certainly must endeavour to make you a visit some time in August or September next. 
I made a sad mistake respecting the time when I received the Ferns [37] for you from Dr. Greville. Even now I barely recollect that I left a parcel for you at Grant Thorburn's seed Store. No tidings have yet been received from the gentleman into whose hands Dr. G. placed also a copy of his Algae Britannicae [26] for me.

I leave for you the Ist Part of Hooker's Boreal Flora [34] (without the plates) which I hope may prove of some use to you. The 4th No. is out in England, but I have not received it yet.

You have perhaps heard of the lamented death of DeCandolle! The news $\left.{ }^{*}\right]$ reached me just at the moment that I closed for him a parcel of rare plants. To our short-sighted vision it appears to be a misfortune that he did not live to finish his great work, but we must submit - the Judge of all the earth always does that which is right.

Our citizens are much alarmed at the prospects of cholera reaching us ere long. Indeed there is too much reason for believing that our fears will be realized, but I trust \& pray that in the midst of wrath, God will remember me mercifully.

In haste I subscribe myself

Your faithful friend

JOHN TORREY

\section{TORREY TO SCHWEINITZ}

My dear Sir,

New YORK, October 22nd I 832

Your letter of the 3oth of August last, together with the two copies of your work on the Fungi [76], reached me safely \& in good time. The copy for Mr. Halsey was sent to him forthwith. I congratulate you on the completion of this great performance. Its appearance will be hailed by all the lovers of Cryptogamic botany, here \& elsewhere. If we now had the other departments of our Acotyledones finished, we [would] have our entire Flora posted up to the present day. When shall we have our Lichenes, our Musci, our Algae \& our Hepaticae? Life is too short-too valuable, I ought to have said, for any one of us to undertake the whole. We must secure the great object of present existence, whatever else we surrender or neglect.

* [This "news" was erroneous.] 
The dreadful Cholera has now almost entirely left us, \& not not one of my family has been touched-or rather none has been smitten down, for several of us have had mild attacks of the disease. Not even any of my relatives or near friends have been removed, though hundreds have fallen around us. Surely it has not been on account of our righteousness that we have been spared. It is God, that has preserved us, in his inscrutable sovereignty.

I regret to hear, my dear Sir, that your health has not been established-that on the contrary, you grow more feeble. I pray that you may be patient \& resigned, \& that all your afflicticns may be turned to the profit of your soul, by him who says that "affliction cometh not forth of THE DUsT."

A few days ago I received a large collection of plants from the Arkansas country,-embracing about 300 species. Many of them are exceedingly curious and interesting- $\&$ not a few of them quite new. I have a few duplicates of the rarer species, which I will send to you by an early opportunity. Some of the plants had been collected by Nuttall, in I8I9 \& I820. These have mostly been described \& sent to De Candolle for publication. Who is to continue De Candolle's Prodromus [I6]? I suppose you have heard of the death of this great man. The 5 th vol. embracing the Compositae, must have been completed before his death.

Last week my wife \& eldest daughter embarked for Europe. They are to spend the winter with our relations in Ireland, \& I hope, with leave of Providence, to join them early in the spring. It is my intention to take over as many of our doubtful plants as possible \& compare them with the original specimens in the herbaria of Pursh, Hooker, Michaux, \& others who have written on our Botany. If you have any plants which you should like to have compared, I hope you will send them to me in the course of the winter.

Excuse this short \& uninteresting letter, \& believe me, my dear Sir,

Truly \& affectionately yours JOHN TORREY

Revd. L. De Schweinitz 


\section{TORREY TO SCHWEINITZ ,}

My dear Sir.

New York, August 24th 1833

By the blessing of God I have safely returned to my native land, \& to my happy home, after being so long separated from them. Although I am by no means fairly settled yet, I must address you a few lines, to enquire about your health \& also to inform you that a parcel from Dr. Hooker will immediately be sent, for you, to the store of Mr. Bininger, in Broadway. The said parcel was placed in a box at Glasgow last April, \& forwarded to New York, but my family misunderstood my directions, \& did not leave it, as addressed, or you would have received it long since.

I have had a pleasant time of it in Europe, though my stay was too short to accomplish all that I desired to do. I spent more than a month in Dr. Hooker's family, from whom I received every possible kindness. Dr. H. is a delightful man, \& one of the most liberal botanists in the world-I was positively ashamed to take so many plants \& books from him without the possibility of my making any suitable return. At Kinross I spent a week with Dr. Arnott, who is a most accurate botanist. He is working, along with Dr. Wight, at a Flora of Peninsular India [94]. In Edinburgh I made the acquaintance of the excellent Prof. Graham-

In London I went through Pursh's Herbm. in Mr Lambert's possession, \& also Gronovius' plants in the British Museum. I was much pleased with Mr. Brown who is an astonishing man. We became quite intimate, $\&$ he is to furnish me with some remarks on several interesting American plants. I saw much of Lindley, Bentham, \&c.

In Paris I worked hard at [the] Michaux Herbm., preserved at the Garden of Plants, \& have settled many doubts which have hung over his plants.

You must write to me as soon as convenient \& let me know what is the state of your health, \& what you have been doing in the botanical way since I have been absent. I am sorry that I cannot write to you at greater length at present.

Believe me, My Dear Sir

Yours very truly,

JOHN TORREY 


\section{TORrey TO SCHWEINITZ}

\section{My Dear Sir}

\section{New York, November 2nd I 833}

If you were to judge from my great delay in replying to your letters that I valued your correspondence but little I could hardly blame you very much, were you unacquainted with the fact that I am occupied in many concerns besides botany. But you know that I have my hands full of business, \& that if I am not so prompt a correspondent as some others, it is not always my fault. Since I received your kind letter of the 2 nd of September last I have attended as much to plants as possible \& have not forgotten you when any duplicates came in my way.-But I will first reply to your letter before I make any remarks on other matters. I am much pleased to hear of your improved health, \& hope that you will not soon be so dreadfully afflicted as you were for some time before I left this country for Europe. You must have suffered much if you are willing to compound for Gout! The parcel which Dr. Hooker consigned to my care no doubt reached you safely, \& I know that the contents pleased you much. I was present when the specimens were selected for you by our excellent friend,Mrs. H. wrote your labels, while the Dr. called out the names.The parcel left at Mr. Van Vleck's on the 6th of December last (I keep an exact record of all my doings in this way) contained your shares of Gates' last plants (some very good things) \& some duplicates of Dr. Pitcher's collections on the Arkansas \& Red Rivers. You may yet find the parcel-for on my return from Europe I received my long expected copy of Dr. Greville's Algae britan. [26] which was between two \& three years on its way to me.

I rejoice in your acquisition of Dr. Baldwin's plants, though you may suspect that my joy is not without some selfish feeling,for you generously offer me a share of your duplicates. By this time you must have completed the examination of your treasures, \& have learned the value of them. The Georgia \& Florida specimens that you may have to spare I shall be most happy to receive. As soon as your list is complete I hope you will allow me to have it by an early opportunity, or by mail, \& I will then mark such as are desiderata with me. In distributing your duplicates I hope you will be able to send a few to our friend Dr. Hooker- 
especially of the S. American species.-Have you any of the Surinam plants left, that you could spare him? He is much interested in S. American Botany. Rafinesque's proposal' for the Duplicates of Baldwin's collection was a strange one! You of course declined it.

Did I tell you that I had made an engagement with Dr. Gray (of Utica), to aid me in my botanical \& chemical labours? He lives in my house, $\&$ is now working daily at my herbarium. My whole collection will soon be arranged according to the Natural method, \& in the spring (D.V.) I shall attack with zeal, my Flora Synopsis of North American plants [92]. Dr. G. will devote part of his time to his own concerns (according to our agreement), $\&$ has made arrangements for publishing collections of dried plants of the more difficult genera \& families:- such as Gramineae, Cyperaceae, Aster, Musci, \&c. He hopes to publish the Ist No. of his N. Am. grasses in the Spring \& the Ist No. of his N. Amer. Mosses about the same time. The price will be $\$ 5$. for Ioo sp. neatly fastened on white paper, with printed title page, index \& labels - with a handsome portfolio. The specimens placed loose [on] herbarium papers, with printed labels-but without the portfolios will be sold at $\$ 4 \mathrm{pr}$. Ioo. - When you write to your German friends please give them this information \& cause it to be printed in some botanical periodical or magazine in Germany. Dr, Gray will spend a month or two every season in collecting specimens from the most interesting localities that are not too remote.

Have you seen the 6th edn. of Eaton's Manual of Botany [20]? I have not examined it-nor indeed have I scarcely seen more than the covers of the book. I began to read the preface in a bookstore the other day, \& it seemed to be a most remarkable performance,--but I was interrupted before I had finished the first page. Dr. Lewis Beck's new Work [7] is a pretty good compilation-but it does not settle many of our difficult plants.

Have you the 6th No. of Hooker's F1. Bor. Amer. [34]? It goes partly through the Compositae. The Dr. hoped to have completed the Ist. Vol with the 6th No. but he finds it necessary to add a 7 th No. The whole work (excluding all the Crypts. but the ferns) will make two volumes of 13 numbers. - It is a charming 
performance.-The amiable author was uncommonly kind to me when I was in Glasgow, \& compelled me to stay a month with him. He is a most industrious man-for besides the Northern Flora, he is writing (with the aid of Mr. Arnott) an account of Capt. Beechey's plants [36]-he prepares every month, a number of Curtis' magazine [18]-he has lately published three volumes of the Bot. Miscellany [Io], \& has a new number ready to publish.besides many other works - so that I cannot conceive how he can do so much \& do it so well. I have no botanical news to give you, of much consequence. My friend Dr. Barratt spent several days of this week with me. He has been studying our Willows for two years past, \& has made many valuable obs. on these obscure plants. I will urge him to send you a set named by himself.

Your obliged \& faithful friend JOHN TORREY 


\section{LITERATURE CITED}

\section{Florence P. SMith}

I. Acharius, Erik.

Synopsis methodica Lichenum. Lund. I8I4.

\section{Agardh, Carl Adolf.}

Icones algarum ineditae. Lund, Stockholm. I820, I82 I.

3.

Species algarum rite cognitae. Greifswald, Lund. I820-28.

\section{4.}

Synopsis algarum Scandinaviae. Lund. I8I7.

5. Albertini, Johannes Baptista von, \& Schweinitz, Lewis David von.

Conspectus fungorum in Lusatiae superioris agro niskiensi crescentium. E methodo Persooniana. Leipzig. 1805.

6. American journal of science. Established by Benjamin Silliman in 1818 .

\section{Beck, Lewis Caleb.}

Botany of the northern and middle states; or, A description of the plants found in the United States, north of Virginia, arranged according to the natural system. Albany. I833.

8.

A synoptical table of the ferns and mosses of the United States. Am. Jour. Sci. I5: 287-297. I 829.

9. Beck, Lewis Caleb, \& Emmons, Ebenezer.

Description of the Grevilleanum serratum, a new genus belonging to the order Musci. Am. Jour. Sci. I I : I83. pl. I. 1826.

I0. Botanical miscellany; containing figures and descriptions of such plants as recommend themselves by their novelty, rarity, or history, or by the uses to which they are applied in the arts, in medicine, and in domestic economy; together with occasional botanical notices and information. [Edited] by IVilliam Jackson Hooker. London. I 8[28]-33.

\section{Brace, John Pierce.}

List of plants growing spontaneously in Litchfield and in its vicinity. Am. Jour. Sci. 4: 69-86, 292-309. I 822.

I2. Bridel [afterwards Bridel-Brideri], Samuel Elisée von.

Muscologiae recentiorum supplementum. Gotha. r806-I9. 
I3. Britton, Nathaniel Lord.

Dr. Torrey as a botanist. Bull. Torrey Club 27: 540-551. I 900.

I4. Brown, Robert.

On Woodsia, a new genus of ferns. Trans. Linn. Soc. Lond. II : I70-I 74. pl. II. I8I3.

I5. Candolle, Augustin Pyramus de.

Regni vegetabilis systema naturale, sive Ordines, genera et species plantarum secundum methodi naturalis normas digestarum et descriptarum. Paris. I 818-21.'

16. Candolle, Augustin Pyramus de, \& Candolle, Alphonse Louis Pierre Pyramus de.

Prodromus systematis naturalis regni vegetabilis. Paris. I82473.

I7. Cürie, Peter Friedrich.

Anleitung die im mittleren und nördlichẹ Deutschland wachsenden Pflanzen auf eine leichte und sichere Weise durch eigne Untersuchung zu bestimmen. Görlitz. I 823 .

18. Curtis's botanical magazine, comprising the plants of the Royal gardens of Kew and of other establishments of Great Britain, with suitable descriptions. Established in 1787 by William Curtis.

19. Dewey, Chester.

Caricography. [Consisting of a long series of articles appearing in] Am. Jour. Sci. vols. 7-42. I 824-I866. [Index to species in vol. 42, pages $\left.325^{-3} 34.\right]$

20. Eaton, Amos.

A manual of botany, for the northern and middle states of America. Third edition. Albany. I822. Sixth edition. I8,33.

2 I. Ehrenberg, Christian Gottfried.

Fungorum nova genera tria. Jahrb. Gewächsk. $\mathbf{I}^{2}: 5^{\mathrm{I}}-58$. I 8 I9.

22. Elliott, Stephen.

A sketch of the botany of South-Carolina and Georgia. Charleston, South Carolina. I818-24. [See Barnhart, J. H. Dates of Elliott's Sketch. Bull. Torrey Club 28: 680-688. D I90I.]

23. Fries, Elias Magnus.

Systema mycologicum, sistens fungorum ordines, genera et species, huc usque cognitas, quas ad normam, methodi naturalis determinavit, disposuit atque descripsit Elias Fries. Lund. I82I-30. 
24.

Systema orbis vegetabilis. Primas lineas novae constructionis periclitatur Elias Fries. Pars I. Plantae homonemeae. Lund. I 825 .

25. Gray, Asa.

John Torrey. Proc. Am. Acad. Arts \& Sci. 9: 262-27 I. I874. [Also published in Am. Jour. Sci. III. 5: 4II-42I. I873; and in Scientific papers of Asa Gray 2: 359-369. I 889.]

26. Greville, Robert Kaye.

Algae britannicae, or Descriptions of the marine and other inarticulated plants of the British Islands, belonging to the order Algae. Edinburgh. I 830 .

27.

Flora edinensis: or, A description of plants growing near Edinburgh, arranged according to the Linnean system. Edinburgh. I 824 .

28.

Scottish cryptogamic flora or coloured figures and descriptions of cryptogamic plants, belonging chiefly to the order fungi. Edinburgh. I $823-28$.

29. Hedwig, Johann.

Species muscorum frondosorum descriptae et tabulis aeneis LXXVII coloratis illustratae. Opus posthumum, editum a Friderico Schwaegrichen. Leipzig, Paris. I80I. [See a]so no. 66.]

30. Hitchcock, Edward.

Description of a new species of Botrychium; with a drawing. Am. Jour. Sci. 6: I03-I04. I 823.

31. Hoffmann, Georg Franz.

Deutschlands Flora oder Botanisches Taschenbuch. Zweyter Theil für das Jahr I795. Cryptogamie. Erlangen. [I795.]

32. Hooker, William Jackson.

The British flora. London. I830. Ed. 2, with additions and corrections. London. I83I.

33 .

British Jungermanniae: being a history and description, with colored figures, of each species of the genus, and microscopical analyses of the parts. London. I8I6.

Flora boreali-americana; or, The botany of the northern parts of British America: compiled principally from the plants col- 
lected by Dr. Richardson \& Mr. Drummond on the late northern expeditions, under command of Captain Sir John Franklin, R. N. To which are added (by permission of the Horticultural Society of London), those of Mr. Douglas, from north-west America, and of other naturalists. London. I 829-I 840 .

35 .

Musci exotici; containing figures and descriptions of new or little known foreign mosses and other cryptogamic subjects. London. I 81 8-20.

36. Hooker, William Jackson, \& Arnott, George Arnott Walker.

The botany of Captain Beechey's voyage. London. I 8[30-]4I.

37. Hooker, William Jackson, \& Greville, Robert Kaye.

Icones filicum ad eas potissimum species illustrandes destinatae, quae hactenus, vel in herbariis delituerunt prorsus incognitae, vel saltem nondum per icones botanicis innotuerunt. London. I 83 I.

38. Hooker, William Jackson, \& Taylor, Thomas.

Muscologia britannica. London. 1827.

39. Humboldt, Alexander, \& Bonpland, Aimé Jacques Alexandre.

Plantae equinoctiales. Paris. [I 805-17.]

40. Jahrbücher der Gewächskunde. I8I8-20. Berlin \& Leipzig. Edited by K. Sprengel, A. H. Schrader, and H. F. Link.

\section{I. Keating, William Hypolitus.}

Narrative of an expedition to the source of St. Peter's River, Lake Winnepeek, Lake of the Woods, \&c. \&c. performed in the year 1823 , by order of the Hon. J. C. Calhoun, secretary of war, under the command of Stephen H. Long, major, U. S. T. E. Comp. from the notes of Major Long, Messrs. Say, Keating, and Colhoun, by William H. Keating. Philadelphia. I 824 .

42. Lagasca, Mariano.

Genera et species plantarum, quae aut novae sunt, aut nondum recte cognoscuntur. Madrid. I8I6.

43. Le Conte, John Eatton.

Observations on the North American species of the genus Utricularia. Ann. Lyceum Nat. Hist. N. Y. I: 72-79. I824.

44 .

Observations on the North American species of the genus Viola. Ann. Lyceum Nat. Hist. N. Y. 2: I 35-I53. I 826.

45. Lindley, John.

An introduction to the natural system of botany. London. I 830 . 
46.

An introduction to the natural system of botany ... Ist American edition with an appendix. By John Torrey. New York. I83I.

47 .

A synopsis of the British flora. London. I 829.

48. Linné, Carl von.

... Systema vegetabilium. Editio nova, speciebue inde ab editione XV, detectis aucta et locupletata. Curantibus Joanne Jacobo Roemer ... et Jos. Augusto Schultes. Stuttgart. I 8 I $7-30$.

49. Loudon, John Claudius, ed.

An encyclopaedia of plants. London. I 829.

50. Magazine of natural history ... Editors: i 829-36, J. C. Loudon and John Denson; i $837-40$, Edward Charlesworth. Merged into the Annals of natural history, which continued, as the Annals and magazine of natural history.

\section{I. Martius, Karl Friedrich Philipp von.}

Nova genera et species plantarum. Munich. I 823-32.

\section{Muhlenberg, Gotthilf Henry Ernest.}

Catalogus plantarum Americae septentrionale, huc usque cognitarum indigenarum et cicurum. Lancaster. I8I3. Ed. 2. Philadelphia. I8 8 .

53. Nees von Esenbeck, Christian Gottfried Daniel.

Das System der Pilze und Schwämme. Würzburg. I8I6-I7.

54. Nuttall, Thomas.

Collections towards a flora of the territory of Arkansas. Trans. Am. Phil. Soc. 5: 139-203. I 837.

55.

Genera of North American plants. Philadelphia. I818. 56.

A journal of travels into the Arkansa Territory, during the year I8I9. Philadelphia. I82I.

57. Palisot de Beauvois, Ambroise Marie François Joseph.

Muscologie, ou Traité sur les mousses. Mém. Soc. Linn. Paris I : $388-472$. I 822 .

58.

Prodrome des cinquième et sixième familles de l'æthéogamie.

Les mousses. Les lycopodes. Paris. I 805 .

59. Persoon, Christiaan Hendrik.

Synopsis methodica fungorum. Göttingen. I80I. 
6o. Philadelphia academy of natural sciences. Journal. Established in 1817 .

6I. Pursh, Frederick Traugott.

Flora Americae Septentrionalis. London. I8I4.

62. Quarterly journal of science, literature, and art. Edited at the Royal institution of Great Britain, by IV. T. Brande.

\section{Rafinesque, Constantine Samuel.}

Atlantic journal and friend of knowledge. Philadelphia. I 8.32-33.

64. Richardson, John.

Botanical appendix. In Franklin, Sir John. Narrative of a journey to the shores of the polar sea in the years 1819,20 , $2 \mathrm{I}$, and 22. p. 729-763. London. I823.

65. Rudge, Edward.

Descriptions of some new species of Carix from North America. Trans. Linn. Soc. London 7: 96-I00. pl. 9-IO. 1804.

66. Schwägrichen, Christian Friedrich.

Joannis Hedwig Species muscorum frondosorum. Supplementum. I 8 I I-42.

\section{Schweinitz, Lewis David von.}

An analytical table to facilitate the determination of the hitherto observed North American species of the genus $\operatorname{Carcx}$. Ann. Lyceum Nat. Hist. N. Y. I : 62-7I. I824.

68.

Attempt of a monography of the Linnean genus Viola, comprising all the species hitherto observed in North America. Am. Jour. Sci. 5: 48-8I. I 822 .

69.

A catalogue of plants collected in the Northwest territory by Mr. Thomas Say in the year I823. In Keating, William $H$. Narrative of an expedition to the source of St. Peter's River 2: 379-400. Philadelphia. I 824 .

70.

List of the rarer plants found near Easton, Penn. Am. Jour. Sci. 8: 267-269. I 824 .

71 .

Monograph of the North American species of Carex. Ann. Lyceum Nat. Hist. N. Y. I : 283-373. pl. 24-27. I825.

72

On two remarkable Hepatic mosses found in North Carolina. Jour. Acad. Nat. Sci. Phila. 2: 36I-370. I 822. 
73.

Remarks on the plants of Europe which have become naturalized in a more or less degree, in the United States. Ann. Lyceum Nat. Hist. N. Y. 3: I48-I 55. I 835 .

74 .

Specimen florae Americae septentrionalis cryptozamicae ; sistens muscos hepaticos huc usque in Am. Sept. observatos. Raleigh ]North Carolina]. I82 I.

75 .

Synopsis fungorum Carolinae superioris secundum observationes Ludovici Davidis de Schweinitz [!] Ed. a D. F. Schwägrichen. Schrift. Naturf. Gesell. Leipzig I: 2 I-I3I. I 822.

76.

Synopsis fungorum in America boreali media degentium secundum observationes. Trans. Am. Phil. Soc.. 4: I4I-3I6. pl. I9. I 832 .

77. Shear, Cornelius Lott, \& Stevens, Neil Everett.

Studies of the Schweinitz collection of fungi. I-II. Mycologia 9: I9I-204, 333-344. pl. 8-9. I9I9.

78. Sibthorp, John.

Flora graeca. London. I 806-40. .79 .

Florae graecae prodromus. London. I806-I3.

8o. Smith, James Edward.

Compendium florae britannicae. London. I8I6.

$8 \mathrm{I}$.

A selection of the correspondence of Linnaeus, and other naturalists, from the original manuscripts. London. I82I.

82. Sowerby, James.

Coloured figures of English fungi or mushrooms. London. I 797-I 815.

83. Spix, Johann Baptist von, \& Martius, Carl Friedrich Philipp von.

Reise in Brasilien auf befehl Sr. Majestät Maximilian Joseph I., Königs von Baiern, in den Jahren 1817 bis 1820 . München. I 823-3I. [Translated into English by H. E. Lloyd. 2 v. in I. London. I 824.]

84. Sprengel, Kurt Polycarp Joachim.

Neue Entdeckungen im ganzen Umfang der Pflanzenkunde. Leipzig. I 820-22.

85. Thurber, George.

Inaugural address [before the Torrey Botanical Club]. Bull. Torrey Club 4: 26-38. I 873 . 
86. Torrey, John.

Catalogue of plants growing spontaneously within thirty miles of the city of New York. Albany, New York. I8I9.

87.

A compendium of the flora of the northern and middle states. New York. I 826.

88.

Descriptions of some new grasses collected by Dr. E. James in the expedition of Major Long to the Rocky Mountains, in I8I9I820. Read May I7th, I824. Ann. Lyceum Nat. Hist. N. Y. I : I48-I56. pl. IO. I 824 .

89.

A flora of the northern and middle sections of the United States. New York. I8[23-]24.

90.

Notice of plants collected by Professor D. B. Douglass of West Point in the expedition under Governour Cass, during the summer of 1820 around the Great Lakes and the upper waters of the Mississippi. A.m. Jour. Sci. 4: 56-69. 1822.

9 I.

Some account of a collection of plants made during a journey to and from the Rocky Mountains in the summer of I820, by Edwin P. James, M. D. Assistant Surgeon U. S. Army. Ann. Lyceum Nat. Hist. N. Y. 2: I6I-254. I.826-7.

\section{Torrey, John, \& Gray, Asa.}

A flora of North America; containing abridged descriptions of all the known indigenous and naturalized plants growing north of Mexico; arranged according to the natural system. New York, London. I 838-4[3].

93. Weber, Friedrich.

Historiæ muscorum hepaticorum prodromus. Kiel. I8I.5.

94. Wight, Robert, \& Arnott, George Arnott Walker.

Prodromus florae peninsulae Indiae Orientalis: containing abridged descriptions of the plants found in the peninsula of British India, arranged according to the natural system. London. I 834 . 
BIOGRAPHICAL NOTICES OF PERSONS MENTIONED IN THE SCHWEINITZ-TORREY CORRESPONDENCE

JOHN HENDLEy BaRNHART

Agardh, Carl Adolf (I785-1859). Professor at Lund, Sweden, and bishop of Karlstad; famous as the foremost student of algae of his day.

Arnott, George Arnott Walker (I799-I868). Regius professor of botany at Glasgow, Scotland; author (with W. J. Hooker) of "British botany" and "The botany of Captain Beechey's voyage."

Baldwin, William (I779-I8I9). American physician; plant collector in the southeastern United States and in South America; appointed botanist to Long's expedition for the exploration of the upper Missouri, but was obliged to stay behind at Franklin, Missouri, where he died a few weeks later.

Barratt, Joseph (I797-I882). Physician, of Middletown, Connecticut; specialist in the genera Salix, Carex, and Eupatorium.

Beck, Lewis Caleb (I798-I853). Physician and naturalist, of Albany, New York; his scientific interests were about equally divided between mineralogy, chemistry, and botany.

Bentham, George (1800-I 884). British botanist; a man of independent means, and an indefatigable worker and prolific writer upon plants; for twelve years president of the Linnean Society of London. He had published but little, but his reputation was already established, at the time of Schweinitz's death.

Bridel-Brideri, Samuel Elisée von (I76I-I 828). Famous bryologist, of Swiss birth, but long attached to the ducal house of Saxe-Gotha, at first as tutor, then as secretary, librarian, and member of diplomatic missions to the court of Napoleon and to the Pope. His "Muscologia recentiorum" (I797-I822) and "Bryologia universa" (I826-27) are recognized as classics by students of mosses.

Brown, Robert (I773-I858). Botanist to the Flinders expedition for the exploration of Australia; librarian to Sir Joseph Banks and the Linnean Society of London; for thirty years Keeper of the Botanical Department of the British Museum. 
Candolle, Augustin Pyramus de (I778-184I). Famous Swiss botanist; author of many works, of which perhaps the best known is the "Prodromus."

Casström, Samuel Niklas (I763-1827). Swedish statesman; Knight of the Polar Star; one of Thunberg's earliest pupils at Upsala; his dissertation ( $\mathrm{I} 78 \mathrm{I}$ ) was entomological, and he never published anything in botany, although known to his friends and correspondents as one who was interested in that science.

Collins, Zaccheus (I764-I83I). Philadelphia philanthropist; member of various learned societies; correspondent of Muhlenberg, Elliott, Nuttall, Torrey, and other botanists; highly esteemed for his botanical knowledge; but published nothing. For him Nuttall named the genus Collinsia.

Conrad, Solomon White (I779-I83I). Philadelphia bookseller and publisher; minister of the Society of Friends; amateur naturalist for years; during the last two years of his life professor of botany in the University of Pennsylvania; father of Timothy Abbott Conrad, the famous conchologist.

Cooley, Dennis (I789-I860). Physician; first at his native place, South Deerfield, Mass.; for three years, I822-25, at Monticello, Georgia; and from 1827 at Washington, Macomb County, Michigan, where he was postmaster for 23 years. He was from his youth an ardent field-botanist, and accumulated one of the largest private herbaria in America; this was presented by his widow, in $\mathbf{I} 863$, to the Michigan Agricultural College.

Cooper, William (I798-I864). Well-known zoologist, his interest in botany being secondary but keen; original member, and for 46 years an officer, of the Lyceum of Natural History of New York (now the New York Academy of Sciences); father of James Graham Cooper, naturalist of the Pacific Railroad Survey and later of the Geological Survey of California.

Cürie, Peter Friedrich (I 777-I 855). Moravian clergyman; bishop for thirty years (I825-55). He was the author of a small pocket key to the plants of middle and northern Germany (I823), which proved its usefulness by passing through many editions up to as late as i89I. He seems to have been almost unknown to his botanical contemporaries; it is therefore interesting to learn that he was one of the most intimate friends of Schweinitz in Germany.

Darlington, William (I782-I863). Physician, statesman, and banker, of West Chester, Pennsylvania; member of many scientific societies 
in America and Europe; author of books on the flora of Chester County, and on economic plants; editor and publisher of the letters of Bartram, Marshall, and Baldwin.

Davis, Emerson (I798-I866). Graduate of Williams College (I82I); trustee of the same institution from 1833 , and vice-president from I 859. Engaged in educational work until 1836 , he was a clergyman at Westfield, Massachusetts, for the remainder of his life. In youth he was interested in geology and botany, and devoted particular attention to the study of the genus Carex.

DeKay, James Ellsworth (I792-I85I). New York physician; early member of the Lyceum of Natural History; zoologist to the State Survey, and author of the zoological volumes of the Natural History of New York.

Delile, Alire Raffeneau ( $177^{8-1850) . ~ F r e n c h ~ p h y s i c i a n ; ~ w h e n ~ o n l y ~}$ twenty years of age he was one of the scientists chosen to accompany the Napoleonic expedition to Egypt, and was placed in charge of the botanic garden then established at Cairo. From I 803 to 1805 he was French vice-consul at Wilmington, N. C., and then studied medicine in New York City, receiving his M.D. degree from Columbia College.in $\mathrm{I} 807$, and returning to France in the same year. The last thirty years of his life he was professor at the university of Montpellier and director of the botanic garden there. He is best known for his elaborate works on the flora of Egypt (1810-24).

Denke, Christian Frederick (1775-I 838). Moravian clergyman; born at Bethlehem, Pa.; educated at Nazareth Hall, and teacher there I796-I800; missionary to the Indians of Canada, at Fairfield, in western Ontario, $1800-18$; at home in Bethlehem, I8I8-20; pastor at Hope, "North Carolina, I820-22, and at Friedberg, N. C., I $822-3 \mathrm{I}$; retired in $\mathrm{I} 83 \mathrm{I}$, spending the rest of his life at Salem, N. C., where he died. He was associated botanically with Muhlenberg as well as with Schweinitz.

Dewey, Chester (I784-I867). American educator; professor at Williams College and the University of Rochester; specialist in the genus Carex.

Douglass, David Bates (I790-I849). United States military engineer; graduate of Yale; professor at West Point throughout the period of Torrey's connection with the military academy; afterward professor at New York University, Kenyon College, and Hobart College. He accompanied the Cass expedition to the upper 
Mississippi in 1820 , and collected plants in that region, then little known botanically. He was a son-in-law of Major Andrew Ellicott (I754-1820), the famous surveyor.

Drummond, Thomas ( $1780-1835)$. Plant-collector in arctic America, Canada, and Texas, for the Glasgow Botanical garden; student of mosses.

Eaton, Amos (I776-I842). Lecturer and writer; graduate of Williams College; the greatest popularizer of natural science that America has ever known. He was Torrey's first botanical teacher; his "Manual of botany," which went through eight editions (I8I740), was in its day the field reference book for every botanical student in the northeastern United States. He was the organizer of the Rensselaer polytechnic institute, at Troy, New York, in I 824, and its senior professor from that time until his death.

Eights, James (I798-I882). Physician and naturalist, of Albany, New York; correspondent of Eaton and Torrey, and friend of Beck; as naturalist accompanied the Fanning expedition to the South Sea islands in 1829 .

Elliott, Stephen (I77I-I830). One of the most distinguished citizens of South Carolina; representative, senator, and first president of the State Bank; author of a scholarly two-volume flora of South Carolina and Georgia, modestly entitled a "Sketch"; father of Stephen Elliott, first Protestant Episcopal bishop of Georgia.

Fries, Elias Magnus (I794-I878). Swedish botanist; for twenty years (1814-34) a member of the faculty at Lund, and for twentyfive years (1834-59) professor at Upsala. His was the most commanding figure in the early history of mycological taxonomy.

Frueauff, Eugene Alexander (I806-1879). Moravian clergyman and educator; nephew of Schweinitz (son of his sister Elizabeth and her husband Rev. John Frederick Frueauff). He was his uncle's assistant at Bethlehem, accompanied him on his western journey to Hope, Indiana, in May, June, and July, I83I, and succeeded him as administrator of the temporal affairs of the Moravian church in America; he was for twenty years principal of Linden Hall, a Moravian school at Lititz, Pennsylvania. Through his association with his uncle he became interested in botany; after his death his herbarium was presented by his widow to the Moravian college at Bethlehem. (For these data I am indebted to his son, Professor Herman T. Frueauff, of the Frances Steitler School, Allentown, Pennsylvania.) 
Gates, Hezekiah (17-I850?). _Physician and apothecary for many years at Mobile, Alabama; first resident collector of the plants of that vicinity.

Graham, Robert (I786-I845). Professor of botany for a few years at Glasgow, and for 27 years at Edinburgh, Scotland; president of the Botanical Society of Edinburgh.

Gray, Asa (I8I0-I888). The most famous American botanist of his time, professor at Harvard for forty-six years. Before going to Harvard he was long associated with Torrey in work upon the North American flora; the beginning of their relations is referred to in Torrey's last letter to Schweinitz.

Greene, Benjamin Daniel (I793-I862). Capitalist, of Boston, Massachusetts; thorough student and liberal patron of botany; one of the founders, and the first president, of the Boston Society of Natural History.

Greville, Robert Kaye (I794-I866). Scottish philanthropist, of Edinburgh, noted for his diligent work and extensive publication in the field of cryptogamic botany.

Halsey, Abraham (I790-I857). Book-keeper and bank-clerk in New York City; first American specialist in lichənolozy; member of the Lyceum of Natural History of New York.

Hitchcock, Edward (I793-I864). Geologist and botanist; principal of the academy at Deerfield, Mass., I8I5-I8; Congregational clergyman, I82I-25; professor at Amherst College, I 825-64, and its president for ten years, I845-54; state geologist of Massachusetts, I830-44. He was the first presiding officer (I840) of the Association of American Geologists, and was one of the original members (I 863) of the National Academy of Sciences. He was the author of numerous books and papers on geological, religious, and historical topics; also two plant catalogues, one (I829) relating to the vicinity of Amherst, the other (I 833; revised, I 835) to the state of Massachusetts.

Hooker, William Jackson (1785-I865). Regius professor of botany at Glasgow, Scotland; afterward, for the last twenty-five years of his life, director of the Royal Gardens, Kew, England; knighted, I836. Author of many monumental works in various branches of botanical science.

Hüffel, Christian Gottlieb ( $1 ;-62-1842)$. Moravian bishop; in charge of the work in the northern part of the United States from I8I 8 until 1825 , when he returned to Germany. 
Ives, Eli (I779-I86I). Physician and botanist; graduate of Yale, I799; practiced medicine at New Haven, with his father, I80I-I3; became professor at Yale upon the establishment of the medical school in I8I3, and so continued until his retirement in 1852 . He devoted much time to his botanical garden. He published an account of the vegetation of New Haven in Dwight's "Statistical account" (I8II), and was one of the authors of the "Catalogue of plants found within five miles of Yale College" (I $83 \mathrm{I}$ ). Several of his botanical papers appeared in the American Journal of Science.

James, Edwin (I797-I86I). American physician; botanist and geologist of Long's expedition to the Rocky Mountains of Colorado in I 8I9-20; editor of the published report of that expedition.

\section{Lamarck, Jean Baptiste Antoine Pierre Monnet de (I744-I829).} French naturalist; famous first as a botanist, and later for many years as professor of zoology at the museum of natural history in Paris.

LeConte, John Eatton (I784-1860). American botanist and entomologist; topographical engineer, United States army; one of the founders of the Lyceum of Natural History of New York.

LeConte, Lewis (1782-1838). Physician; graduate of Columbia College; planter in Georgia; known to his contemporaries as an excellent botanist, but he published nothing, and is consequently not as well known to the botanists of to-day as his younger brother John Eatton Le Conte.

Lederer, Ignaz Ludwig Paul von (I769-I849). Austrian baron; consul-general to the United States; mineralogist; collected and sent home plants while in America ( $c f$. Flora 9: 242, 270. I825).

LeSueur, Charles Alexandre (I778-I846). French zoologist and author; with the French exploring expedition to Australia in I80005, shipping as a member of the crew of "Le Geographe," but advanced early in the voyage to an important place on the scientific staff. In I 8 I 5 he accompanied Maclure to America, and with him settled in 1825 at New Harmony, Indiana, where he remained until 1837 , when he returned to France.

Lindley, John (I799-I865). Famous British botanist; author of numerous books, especially on plant classification in general and on orchids; for nearly forty years the mainspring of the Royal Horticultural Society; founder of the "Gardeners Chronicle" in I 84 I, and its editor until his death. 
Maclure, William (I763-I840). Geologist; of Scottish birth, he early became a partner in a commercial house in London, where he rapidly acquired a considerable fortune. From 1796 he made his home in the United States, although he spent much of his time in travel, both in America and in Europe. He was a member of the New Harmony community, I825-27. From December, I8I7, until his death, he was president of the Academy of Natural Sciences of Philadelphia; during that period he presented more than 5000 volumes, many of them very rare, to the Academy's library, and his gifts in cash to the Academy during the same period exceeded $\$ 25,000$.

Madianna, Jean Baptiste Ricord-(I787-1827). Physician; of French birth, but came to America in his youth; graduated in medicine at Columbia College, New York, in I817; practiced his profession chiefly in the West Indies, where he earned a wide reputation. He was particularly interested in medicinal and poisonous plants, and several of his published papers relate to them.

Martius, Carl Friedrich Philipp von (1794-I 868). Famous German botanist and explorer; acting director of the royal botanic garden at Munich from I8I6, and its director from I835; author of numerous botanical works, including a magnificent one upon palms; founder of the "Flora brasiliensis" and its editor until his death.

Michaux, André (1746-1802). French botanist; pupil of Bernard de Jussieu, and friend of Lamarck, Thouin, and Richard. From I 782 to 1785 he was engaged in the botanical exploration of Persia; from $\mathrm{I} 785$ to $\mathrm{I} 796$ he was similarly employed in the eastern United States and Canada; afterward he accompanied the French exploring expedition of I800-05 (see LeSueur, above) as far as Madagascar, where he died. His "Flora boreali-americana," edited anonymously by L. C. Richard, was published in $\mathrm{I} 803$.

Michaux, François André (I770-I 855). Son of the preceding; was with his father in America from 1785 to 1790 , and subsequently visited this country twice, $\mathrm{I} 80 \mathrm{I}-03$ and $\mathrm{I} 806-07$; friend of nearly all of the few American botanists of that period, including Muhlenberg, Barton, Hosack, Eddy, and LeConte; author of the "North American sylva" (in French, I8IO-I3; in English, I8I7-I9 and later editions) and other works.

Mitchell, Elisha (1793-I857). Chemist and geologist; graduate of Yale, 1813; clergyman and professor in the University of North Carolina from I 818 until his death nearly forty years later; through- 
out this period he was a keen student of the flora of the state (one page of his manuscripts is headed "Catalogue of plants to be sent to Mr. Schweinitz"), but his published papers include none with botanical titles. He lost his life on the mountain to which he had devoted much study and which has since borne his name, Mount Mitchell, the highest peak in the United States east of the Rockies.

Muhlenberg, Gotthilf Henry Ernest (1753-I8I5), Lutheran clergyman; native of Pennsylvania, but educated for seven years in Germany; pastor for thirty-five years (I780-1815) at Lancaster, Pennsylvania. He began the study of botany before going to Lancaster, and continued it diligently throughout his life. His manuscript notes contained full descriptions and comments upón all the plants he studied, but only the part relating to grasses appeared in print in full, and this not until after his death. His floras and catalogues published during his lifetime, although full of records of novelties, were little more than barren lists of names. He was in correspondence with many European botanists, as well as American ones.

Nuttall, Thomas (I786-1859). Botanist and ornithologist; native of England, where he spent the last eighteen years of his life; most of his scientific activity, however, was during the thirty-three years ( $1808-4 \mathrm{I})$ of his residence in the United States. His little work, "Genera of North American plants" (I818), is one of the classics of American botany.

Oakes, William (I799-I 848). New England botanist, devoted particularly to the study of the flora of New Hampshire, Vermont, and eastern Massachusetts; his extensive collections, to be found in many herbaria, are remarkable for their excellence. He was a graduate of Harvard, and educated for the law, but gave up his profession after only a few years to devote his time entirely to scientific study.

Percival, James Gates (I795-I856). Poet and geologist; medical graduate of Yale; for a few months in I 824 professor of chemistry at West Point; afterward state geologist of Connecticut (I $835^{-42}$ ) and of Wisconsin (I 854-56).

Perrin, - French collector of plants in the West Indies, about i 8o8; brought his collections to New York, where he died; his plants afterward fell into the hands of Hosack and Torrey, and some of them were described by Sprengel. Torrey's letter of October I2, I 82 I, tells more about Perrin than appears to have been printed hitherto. 
Persoon, Christiaan Hendrik (I755-I837). A botanist whose mycological works are deservedly regarded as classics; born in South Africa, of Dutch-Hottentot parentage, and of extremely repulsive appearance and habits; spending his last years in poverty in Paris; nevertheless his name occupies a permanent place of honor in the history of botany.

Pickering, Charles (I805-I878). American botanist, zoologist and anthropologist, noted for his profound scholarship; graduate of the Harvard Medical School; member of the staff of the Wilkes Exploring Expedition, I838-42, and explorer in Egypt, Arabia, India, and eastern Africa, $1843-44$, residing in Boston for the remainder of his life. From 1827 to 1838 he lived in Philadelphia, and was active in the work of the Academy of Natural Sciences as curator and librarian; he supervised the transfer of the Schweinitz collections to the herbarium of the Academy in 1834 .

Fitcher, Zina (I797-I872). Physician and naturalist; United States army surgeon, in service on the frontier, $1822-36$; thereafter a resident of Michigan; president of the Army Medical Board and of the American Medical Association; regent and professor of the University of Michigan; mayor of Detroit.

Prince, William (I766-I842). Horticulturist; proprietor of the "Linnean Botanic Garden" at Flushing, New York, a commercial enterprise, but one conducted with more regard for the advancement of American horticulture than for profit; author of a "Treatise on horticulture" (I 828 ).

Pursh, Frederick (I774-I820). Student of the North American flora; native of Saxony; spent about twelve years (I799-I8II) in the United States, traveling, studying plants, and serving as a gardener at Philadelphia and New York; went in I8I I to England, where he continued his studies, and where his "Flora Americae septentrionalis" was published in January, I8I4; later he went to Canada to continue his work of botanical exploration, and died at Montreal.

Rafinesque, Constantine Samuel (I783-I840). Brilliant but eccentric naturalist; of Franco-German parentage; born in Constantinople; educated in Italy, where he very early became a student of the natural sciences, especially botany; in youth he spent three years (1802-05) in America, at Philadelphia; then lived for ten years in Sicily, returning in 1815 to the United States, where he remained throughout his career; from 1819 to 1825 he was a professor at 
Transylvania University (now the State University of Kentucky); for the rest of his life his home was in Philadelphia, where he died in poverty.

Richardson, John (I787-I865). Scottish zoologist; naturalist of the Franklin expeditions of $1819^{-22}$ and $1825^{-27}$; knighted I846; commander of an expedition in search of Franklin, I848-49. He collected plants on all of his travels and wrote the botanical appendixes to the reports of Franklin's first journey and his own expedition, as well as several other botanical papers.

Say, Thomas (I787-1834). Zoologist: one of the earliest members of the Academy of Natural Sciences of Philadelphia, from I8I2 onward, and one of its most energetic and brilliant promoters: naturalist to both of Long's western exploring expeditions, I8I920 and I823; was a member of the New Harmony community in 1825 , and continued to make his home at New Harmony until his death. His chief interest was in entomology and conchology; in his travels, however, he collected many plants; Rosa Sayi, one of these, was name for him by Schweinitz.

Saynish, Lewis. Physician, at 404 Broadway, New York City, about I $830-32$; this correspondence gives evidence of his familiarity with botany.

Schwägrichen, Christian Friedrich (I775-I 853). German physician, for fifty years (I802-52) a professor on the medical faculty of the university of Leipzig. He was especially interested in the study of cryptogamic plants; it was in his hands that Schweinitz left the manuscript of his synopsis of Carolina fungi in I8I8; and it was he who published it in 1822 , Schweinitz knowing nothing of its publication until he received printed copies of it from Schwägrichen.

Scouler, John (I804-I87I). Scottish physician and naturalist; he collected plants on the west coast of North America in 1825-27, among them the moss upon which his former teacher, the elder Hooker, based the genus Scouleria.

Sealy, - Physician and local botanist, of Bandon, in southern Ireland.

Silliman, Benjamin (I779-I864). American geologist; graduate of Yale, and professor there for nearly sixty years; founder of the "American journal of science and arts," which has now been published consecutively for more than a hundred years. 
Smith, James Edward (1759-1828). One of the most famous of British botanists; purchaser of the herbarium of Linnaeus in 1784 ; founder of the Linnean Society of London, I788, and its first president, I788-I828; knighted, I8I4.

Sprengel, Kurt Polykarp Joachim (I766-1833). German botanist and physician; graduate in medicine of the university at Halle, where he was a professor from I789 until his death forty-four years later; author of many works upon medical and botanical subjects. He was noteworthy for his combination of thorough scholarship and great versatility.

Thorburn, Grant (I773-I863). New York seedsman; native of Scotland, coming to America in I794; also known as a writer, under the pen-name of "Laurie Todd."

Treviranus, Ludolf Christian (I779-I864). German physician; professor of botany at Breslau, I816-30, and at Bonn, I830-64. He was the author of many works, particularly in the fields of plant morphology and physiology.

Van Rensselaer, Jeremiah (I793-I870). Physician and geologist; member of the Lyceum of Natural History of New York, and its corresponding secretary from I 824 to I 836 ; his lectures on geology before the New York Athenaeum in 1825 were published in book form.

Van Vleck, Jacob (I75I-I83I). Moravian clergyman, bishop from I 815; friend and correspondent of Muhlenberg and other botanists; collected plants around Salem, North Carolina, about I8I4.

Van Vleck, William Henry (I790-I853). Moravian clergyman, bishop from I 836; pastor at Philadelphia and New York, and (after the death of Schweinitz) at Salem, North Carolina. Son of Jacob Van Vleck, above-mentioned.

Wallich, Nathaniel (I786-I854). Physician, of Danish birth; went to Serampore as medical attaché in 1807 ; when Serampore was taken over by the British in 1813 , he entered the service of the East India Company and was thenceforth a British subject; superintendent of the Calcutta Botanic Garden; the highest botanical official position in India, I815-46; spent his last years in London.

Wight, Robert ( $1796-1872)$. British botanist; in India from 1819 to I 853, and famous for his publications relating to the Indian flora; superintendent of the Botanic Garden at Madras. 



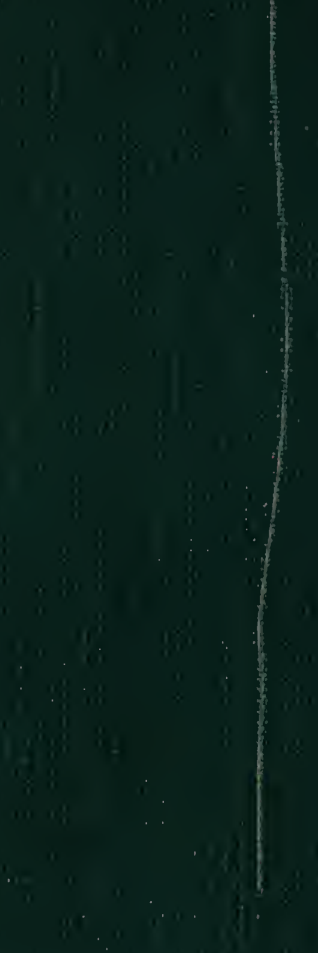

